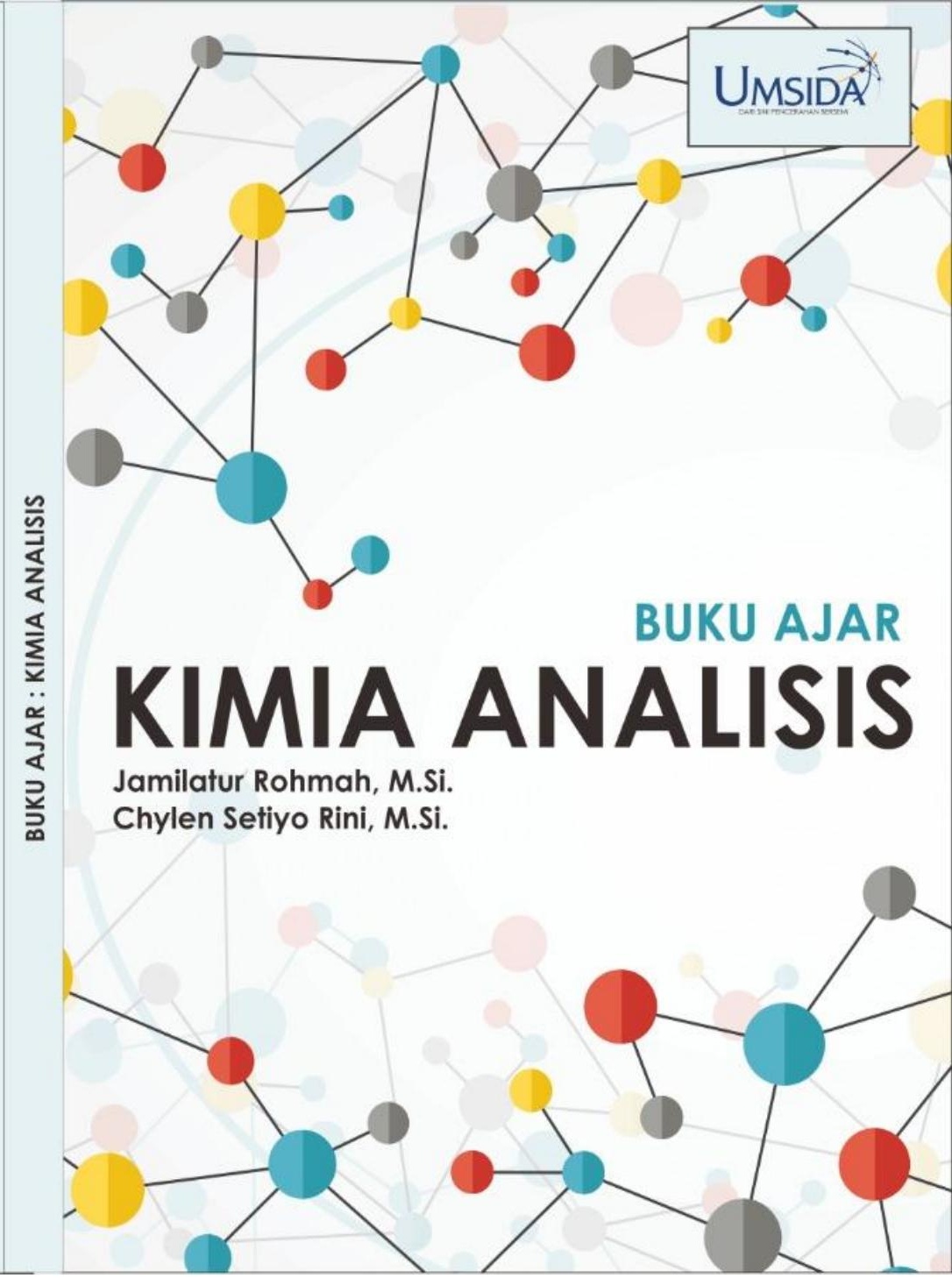




\section{BUKU AJAR \\ KIMIA ANALISIS}

Oleh

Jamilatur Rohmah, S.Si., M.Si.

Chylen Setiyo Rini, S.Si., M.Si.

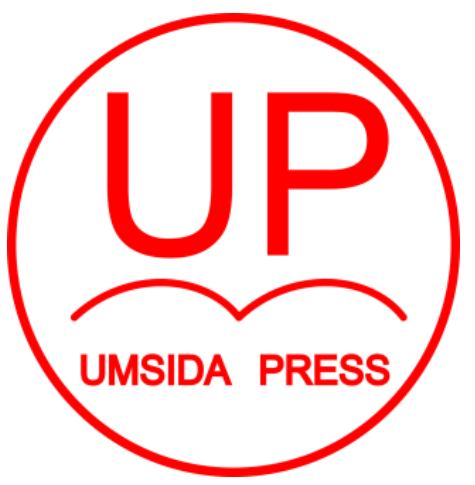

UNIVERSITAS MUHAMMADIYAH SIDOARJO 2020 
BUKU AJAR

KIMIA ANALISIS

Penulis:

Jamilatur Rohmah, S.Si., M.Si.

Chylen Setiyo Rini, S.Si., M.Si.

\section{ISBN :}

978-623-6833-49-0

\section{Editor:}

Galuh Ratmana Hanum, M.Si.

\section{Copy Editor:}

Mahardika Darmawan Kusuma Wardana, M.Pd.

Design Sampul dan Tata Letak:

Mochammad Nashrullah, S.Pd.

Amy Yoga Prajati, S.Kom.

Penerbit:

UMSIDA Press

Anggota IKAPI No. 218/Anggota Luar Biasa/JTI/2019

Anggota APPTI No.002 0181092017

Redaksi

Universitas Muhammadiyah Sidoarjo

Jl. Mojopahit No 666B

Sidoarjo, Jawa Timur

Cetakan Pertama, November 2020

CHak Cipta dilindungi undang undang

Dilarang memperbanyak karya tulis ini dengan sengaja, tanpa ijin tertulis dari penerbit. 
Puji syukur kehadirat Tuhan Yang Maha Esa yang telah melimpahkan hidayahnya sehingga penulis dapat menyusun "Buku Ajar Kimia Analisis" dengan baik. Buku ini membahas mengenai perangkat, dan terminologi kimia analisis, evaluasi data analitik, analisis kolorimetri, analisis gravimetri, dan volumetri.

Buku ini dapat disusun dengan baik berkat kerjasama dan bantuan dari berbagai pihak. Oleh karena itu saya menyampaikan banyak terima kasih kepada segenap pihak yang telah berkontribusi secara maksimal dalam penyelesaian buku ini.

Penulis menyadari bahwa masih banyak kekurangan dalam penulisan buku, baik dari segi tata bahasa, susunan kalimat maupun isi. Oleh karena itu penulis menerima segala kritik dan saran yang membangun dari para pembaca.

Akhir kata semoga buku ini dapat menambah khazanah ilmu pengetahuan dan memberikan manfaat khususnya bagi prodi D-IV Teknologi Laboratorium Medis Fakultas Ilmu Kesehatan Universitas Muhammadiyah Sidoarjo.

Sidoarjo, September 2020

Tim Penulis 


\section{DAFTAR ISI}

Halaman Sampul

Identitas Buku ii

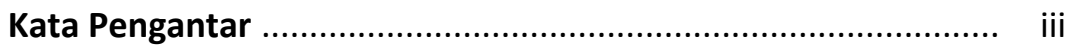

Daftar Isi ......................................................................... iv

Daftar Tabel ................................................................. vii

Daftar Gambar ................................................................. viii

BAB 1. PENGANTAR KIMIA ANALISIS .................................... 1

1.1 Pengertian Kimia Analisis................................ 1

1.2 Penggolongan Teknik Analisa .......................... 2

1.3 Teknik Analisis Kualiatif................................... 2

1.4 Prinsip dalam analisis Kuantitatif..................... 3

1.5 Aplikasi Kimia Analisis ..................................... 8

1.6 Rangkuman ................................................. 11

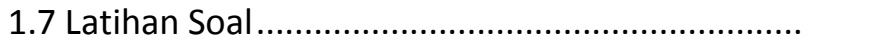

BAB 2. DASAR-DASAR KIMIA ANALISIS ................................. 13

2.1 Reaksi-Reaksi Dasar Analisis .......................... 13

2.2 Konsentrasi Larutan ....................................... 15

2.3 Hubungan Gram, Mol, dan Gram Ekivalen ........ 18

2.4 Preparasi Larutan Standar ............................... 20

2.5 Rangkuman .................................................... 23

2.6 Contoh dan latihan Soal .................................. 24

BAB 3. TITRASI ASIDI-ALKALIMETRI .................................. 26

3.1 Reaksi Asam Basa........................................... 26

3.2 Menghitung pH Selama Titrasi.......................... 28

3.3 Indikator Titrasi ............................................... 29

3.4 Titrasi Asam Kuat dengan Basa Kuat................ 32

3.5 Titrasi Asam Lemah dengan Basa Kuat ............. 33

3.6 Titrasi Basa Lemah dengan Asam Kuat ............. 37

3.7 Titrasi Asam Lemah dengan Basa Lemah........... 38

3.8 Titrasi Asam dan Basa Poliprotik...................... 39

3.9 Titrasi Pemindahan ....................................... 40

3.10 Rangkuman .............................................. 41 
BAB 4. TITRASI ARGENTOMETRI

4.1 Reaksi Pengendapan Titrasi Argentometri ........ 44

4.2 Penentuan Titik Akhir Titrasi........................... 54

4.3 Rangkuman .............................................. 56

4.4 Latihan Soal ................................................ 57

BAB 5. TITRASI KOMPLEKSOMETRI ...................................... 58

5.1 Reaksi Pembentukan Kompleks ....................... 58

5.2 Stabilitas Kompleks ........................................ 59

5.3 Titrasi Pembentukan Senyawa Kompeks ........... 62

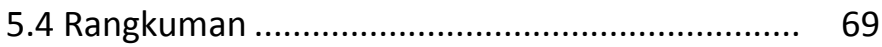

5.5 Latihan Soal ........................................................ 70

BAB 6. TITRASI REDOKS ..................................................... 71

6.1 Perubahan Potensial Reduksi Selama Titrasi ..... 71

6.2 Penentuan Titik Akhir Titrasi.......................... 72

6.3 Titrasi Permanganometri ................................ 76

6.4 Titrasi lodo dan lodimetri ............................... 78

6.5 Titrasi Bikromatometri.................................... 82

6.6 Titrasi Bromatometri..................................... 83

6.7 Rangkuman ................................................ 84

6.8 Latihan Soal ..................................................... 85

BAB 7. ANALISIS GRAVIMETRI ................................................ 87

7.1 Pendahuluan .................................................... 87

7.2 Metode Gravimetri ....................................... 88

7.3 Kemurnian........................................................ 90

7.4 Kondisi Pengendapan..................................... 92

7.5 Tahap-tahap Analisis Gravimetri...................... 93

7.6 Pereaksi Pengendap Organik ........................... 94

7.7 Aplikasi ........................................................ 95

7.8 Rangkuman .................................................... 97

7.9 Latihan Soal .............................................. 98 
BAB 8. ANALISIS VOLUMETRI .............................................. 99

8.1 Hukum-hukum Gas Ideal................................ 99

8.2 Analisis Volumetrik Gas ................................ 106

8.3 Rangkuman ............................................ 108

8.4 Latihan Soal ................................................ 108

BAB 9. ANALISIS KOLOMETRI ............................................ 110

9.1 Dasar-dasar Analisis Kolorimetri ...................... 110

9.2 Hukum Abdorbsi Cahaya oleh Larutan ............. 114

9.3 Syarat Penggunaan Hukum Lambert-Beer......... 115

9.4 Metode Pembandingan Warna........................ 118

9.5 Rangkuman ................................................ 121

9.6 Latihan Soal ................................................. 121

DAFTAR PUSTAKA …............................................................. 122

BIODATA PENULIS ............................................................ 124 
BATANG TUBUH DAN

SUB-CAPAIAN PEMBELAJARAN MATA KULIAH

\begin{tabular}{|c|c|}
\hline BAB & Sub-Capaian Pembelajaran Mata Kuliah \\
\hline $\begin{array}{l}\text { BAB I } \\
\text { PENGANTAR } \\
\text { KIMIA ANALISIS }\end{array}$ & $\begin{array}{l}\text { 1. Mahasiswa Mampu memahami pengertian } \\
\text { Kimia Analisis } \\
\text { 2. Mahasiswa menjelaskan perbedaan analisis } \\
\text { kualitatif dengan analisis kuantitatif; } \\
\text { 3. Mahasiswa mampu memahami penggolongan } \\
\text { teknik analisa dalam kimia analisis } \\
\text { 4. Mahasiswa mampu memahami teknik analisis } \\
\text { kualitatif } \\
\text { 5. Mahasiswa mampu memahami prinsip dalam } \\
\text { analisis kuantitatif } \\
\text { Mampu memahami aplikasi Kimia Analisis }\end{array}$ \\
\hline $\begin{array}{l}\text { BAB II } \\
\text { DASAR-DASAR } \\
\text { KIMIA ANALISIS }\end{array}$ & $\begin{array}{l}\text { 1. Mahasiswa mampu memahami konsep dasar- } \\
\text { dasar analisis. } \\
\text { 2. Mahasiswa mampu menjelaskan dan memahami } \\
\text { reaksi-reaksi dasar analisis. } \\
\text { 3. Mahasiswa mampu menjelaskan dan memahami } \\
\text { konsep hubungan gram, mol, dan gram ekivalen. } \\
\text { 4. Mahasiswa mampu melakukan preparasi larutan } \\
\text { standar. } \\
\text { 5. Mahasiswa mampu memahami analisis titrimetri } \\
\text { baik proses asidi-alkalimetri, argentometri, } \\
\text { dan/atau kompleksometri, reduksi dan oksidasi, } \\
\text { serta analisis gas-gas. } \\
\text { Mahasiswa mampu memahami konsep dan } \\
\text { menerapkan prosedur analisis kuantitatif dalam } \\
\text { pendekatan analisis instrumental: kolorimetri. }\end{array}$ \\
\hline
\end{tabular}




\begin{tabular}{|c|c|}
\hline $\begin{array}{l}\text { BAB III } \\
\text { TITRASI ASIDI- } \\
\text { ALKALIMETRI }\end{array}$ & \begin{tabular}{|lr}
1. & Maha \\
& siswa mampu menjelaskan reaksi asam-basa dan \\
& definisi titrasi asidi-alkalimetri dengan \\
& memberikan contoh dan menuliskan persamaan \\
& reaksinya. \\
2. & Maha \\
& siswa mampu melakukan titrasi asidi-alkalimetri \\
& dan menentukan titik akhir dari kurva titrasi. \\
3. & Maha \\
& siswa mampu membedakan reaksi asam-basa. \\
4. & Maha \\
& siswa mampu menjelaskan hubungan gram mol \\
& dan gram ekivalen.
\end{tabular} \\
\hline $\begin{array}{l}\text { BAB IV } \\
\text { TITRASI } \\
\text { ARGENTOMETRI }\end{array}$ & $\begin{array}{l}\text { 1. Mahasiswa mampu memahami analisis } \\
\text { argentometri. } \\
\text { 2. Mahasiswa mampu menjelaskan reaksi } \\
\text { pengendapan dan definisi titrasi argentometri } \\
\text { dengan memberikan contoh dan menuliskan } \\
\text { persamaan reaksinya. } \\
\text { 3. Mahasiswa mampu melakukan titrasi } \\
\text { argentometri dan menentukan titik akhir dari } \\
\text { kurva titrasi. } \\
\text { 4. Mahasiswa mampu membedakan reaksi } \\
\begin{array}{l}\text { pengendapan dengan reaksi pembentukan } \\
\text { kompleks. }\end{array}\end{array}$ \\
\hline $\begin{array}{l}\text { BAB V } \\
\text { TITRASI } \\
\text { KOMPLEKSOME } \\
\text { TRI }\end{array}$ & \begin{tabular}{|llr} 
1. & Mahasiswa mampu memahami analisis \\
& kompleksometri. & \\
2. & Mahasiswa mampu menjelaskan reaksi \\
& pembentukan kompleks dan definisi & titrasi \\
& kompleksometri dengan memberikan contoh dan \\
& menuliskan persamaan reaksinya. & \\
3. Mahasiswa mampu melakukan titrasi & kompleksometri dan menentukan titik akhir dari \\
& kurva titrasi. & \\
4. & Mahasiswa mampu membedakan reaksi \\
\end{tabular} \\
\hline
\end{tabular}




\begin{tabular}{|c|c|}
\hline & $\begin{array}{l}\text { pengendapan dengan reaksi pembentukan } \\
\text { kompleks. }\end{array}$ \\
\hline $\begin{array}{l}\text { BAB VI } \\
\text { TITRASI REDOKS }\end{array}$ & $\begin{array}{l}\text { 1. Mahasiswa mampu menjelaskan dan memahami } \\
\text { definisi reaksi oksidasi dan reduksi, dan } \\
\text { menjelaskan dasar pengembangan metode } \\
\text { redoks dalam titrasi. } \\
\text { 2. Mahasiswa mampu mengolah data titrasi ke } \\
\text { dalam kurva untuk menentukan titik akhir titrasi. } \\
\text { 3. Mahasiswa mampu melakukan titrasi redoks } \\
\text { dengan berbagai larutan standar (permanganat, } \\
\text { bikromat, bromat, iodin) dan menyelesaikan } \\
\text { perhitungan titrasi redoks. }\end{array}$ \\
\hline $\begin{array}{l}\text { BAB VII } \\
\text { ANALISIS } \\
\text { GRAVIMETRI }\end{array}$ & $\begin{array}{l}\text { 1. Mahasiswa mampu menjelaskan dan memahami } \\
\text { konsep dasar analisis gravimetri. } \\
\text { 2. Mahasiswa mampu melakukan analisis dengan } \\
\text { benar sesuai prosedur. }\end{array}$ \\
\hline $\begin{array}{l}\text { BAB VIII } \\
\text { ANALISIS } \\
\text { VOLUMETRI }\end{array}$ & $\begin{array}{l}\text { 1. Mahasiswa mampu mengetahui hukum-hukum } \\
\text { yang mendasari analisis volumetri gas } \\
\text { 2. Mahasiswa mampu melakukan perhitungan } \\
\text { volumetri. } \\
\text { 3. Mahasiswa mampu melakukan perhitungan } \\
\text { analisis gas dengan metode absorpsi dan } \\
\text { pembakaran }\end{array}$ \\
\hline $\begin{array}{l}\text { BAB IX } \\
\text { ANALISIS } \\
\text { KOLORIMETRI }\end{array}$ & $\begin{array}{l}\text { 1. Mahasiswa mampu memahami dasar-dasar } \\
\text { metode kolorimetri. } \\
\text { 2. Mahasiswa mampu menjelaskan fenomena } \\
\text { absorbsi cahaya oleh larutan. } \\
\text { 3. Mahasiswa mampu menjelaskan dan memahami } \\
\text { hukum Lambert-Beer dan syarat berlakunya. } \\
\text { 4. Mahasiswa mampu melakukan analisis } \\
\text { kolorimetri dengan metode deret standar, } \\
\text { pengenceran, titrasi, dan penyeimbangan untuk } \\
\text { penentuan konsentrasi analit. }\end{array}$ \\
\hline
\end{tabular}




\section{BAB 1}

\section{PENGANTAR KIMIA ANALISIS}

\section{Sub-Capaian Pembelajaran Mata Kuliah}

1. Mampu memahami pengertian Kimia Analisis

2. menjelaskan perbedaan analisis kualitatif dengan analisis kuantitatif;

3. Mampu memahami penggolongan teknik analisa dalam kimia analisis

4. Mampu memahami teknik analisis kualitatif

5. Mampu memahami prinsip dalam analisis kuantitatif

6. Mampu memahami aplikasi Kimia Analisis

\subsection{Pengertian Kimia Analisis}

Kimia Analisis merupakan salah satu cabang ilmu Kimia yang mempelajari tentang pemisahan (separasi), identifikasi, determinasi/menganalisis komponen kimia dalam suatu bahan baik bahan alam maupun bahan buatan. Kimia analisis dapat berupa kimia analisis kualitatif dan kuantitatif. Kimia analisis kualitatif mempelajari tentang identitas suatu bahan kimia yang ada di dalam sampel. Sedangkan kimia analisis kuantitatif berkaitan dengan jumlah suatu komponen bahan dalam sampel. Bahan yang ditentukan disebut analit (konstituen yang diinginkan). Sedangkan jumlah banyaknya suatu zat tertentu dalam sampel dapat dinyatakan dalam bentuk kadar atau konsentrasi, seperti molar, persen berat, gram per liter, normal, atau ppm. Contoh dalam membedakan analisis kualitatif dan kuantitatif yaitu misalnya kapur. 
Kapur dalam analisis kualitatif, dapat diketahui kandungan atau jenis unsur yang ada dalam kapur. Yakni mengandung kation $\mathrm{Ca}^{2+}$ kation dan anion $\mathrm{CO}_{3}{ }^{2-}$ anion. Sedangkan dalam analisis kuantitatif dapat diketahui jumlah zat/unsur yang menyusun kapur dalam bentuk prosentase dari kation $\mathrm{Ca}^{2+}$ dan anion $\mathrm{CO}_{3}{ }^{2-}$.

\subsection{Penggolongan Teknik Analisa}

Menurut tujuannya, kimia analisis dibedakan menjadi kimia analisis kualitatif, kuantitatif, dan struktur. Untuk kimia analisis kualitatif dan kuantitatif seperti yang dijelaskan pada bagian 1.1. sedangkan untuk kimia analisis struktur yaitu berkaitan dengan penentuan letak dan ruang atom dalam suatu molekul. Kemudian, berdasarkan senyawa yang dianalisis dibedakan menjadi dua yaitu senyawa organik dan anorganik. Senyawa organik merupakan senyawa yang berasal dari makhluk hidup dan mengandung karbon. Contohnya yaitu gula, metana, asetilena, dll. Sedangkan senyawa anorganik yaitu senyawa yang berasal dari makhluk tidak hidup dan tidak mengandung karbon. Contohnya yaitu garam $(\mathrm{NaCl})$, air $\left(\mathrm{H}_{2} \mathrm{O}\right)$, asam sulfat $\left(\mathrm{H}_{2} \mathrm{SO}_{4}\right)$, dll. Pembeda dari senyawa organik dengan anorganik yaitu ada/tidaknya ikatan karbon-hidrogen.

Berdasarkan metode, dibedakan menjadi dua yaitu analisis konvensional (klasik) dan modern. Analisis konvensional merupakan analisis yang dilakukan dengan sistem non instrumental seperti reaksi kimia biasa, titrasi, dll. Sedangkan analisis modern yaitu analisis yang dilakukan dengan sistem instrumental seperti spektrofotometer, kromatografi, dll. Selanjutnya menurut jumlah yang dianalisis, kimia analisis digolongkan dalam analisis makro (>100 mg), semimikro (10-100 mg), mikro (0,001 g), ultra mikro $(0,001 \mathrm{mg})$, dan submikrogram $(0,01 \mu \mathrm{g})$. 


\subsection{Teknik Analisis Kualitatif}

Beberapa teknik analisis kualitatif yaitu:

a. Teknik menyaring: ketika melakukan penyaringan jangan sampai saringan penuh, cairan hanya boleh sampai $1 \mathrm{~cm}$ di bawah pinggir kertas saring dan tepi atas kertas saring $1 \mathrm{~cm} \mathrm{di}$ bawah tepi atas corong.

b. Teknik mencuci endapan pada kertas saring: aliran air diarahkan dari botol pencuci dengan langkah pertama-tama di sekitar pinggir atas kertas saring menyusul gerakan spiral menuju endapan dan setiap pencucian, kertas saring terisi antara separuh sampai dua pertiganya.

c. Teknik melarutkan endapan:

1) Pada bagian bawah kertas saring buatlah lubang kecil dengan batang pengaduk dan endapan disemprot dengan pelarut, ditampung di gelas piala kecil atau tabung reaksi.

2) Kertas saring diambil dari corong, dibuka di atas gelas arloji, lalu endapan diambil dan dilarutkan dalam gelas piala.

d. Teknik pengenceran: asam kuat atau basa kuat yang mempunyai bobot lebih besar dari air, teknik pengencerannya dilakukan dengan cara menuangkan asam atau basa tersebut ke dalam air dan bukan sebaliknya (hati-hati dengan asam sulfat pekat).

\subsection{Prinsip dalam Analisis Kuantitatif}

Beberapa hal di bawah ini ditujukan untuk mengenalkan teknik dasar yang perlu diketahui oleh mahasiswa ketika melakukan teknik analisis kuantitatif agar dalam melaksanakan analisis kuantitatif diperoleh hasil yang benar menurut kaidah kimia. 
a. Kebersihan

1) Meja dan alat yang digunakan dijaga tetap dalam keadaan bersih. Sediakanlah serbet meja, serbet alat gelas (dibawa dari rumah).

2) Sebelum digunakan, semua alat gelas dibilas dengan air. Bagian luar diseka dengan serbet sampai kering tetapi bagian dalam tidak (kecuali dilakukan titrasi bebas air).

3) Bagian dalam bejana harus bebas minyak. Alat gelas dicuci dengan deterjen atau sabun dan dibilas dengan air kran sampai bersih.

4) Alat gelas berskala dibilas dengan air yang banyak secepatnya untuk mencegah alat tersebut menjadi panas ketika larutan bercampur dengan air.

b. Kerapian

1) Botol pereaksi (reagen) dikembalikan ke tempat semula jika sudah digunakan. Tutup botol pereaksi jangan diletakkan di atas meja tetapi dipegang dengan tangan kiri.

2) Semua larutan dan serbuk harus ditutup untuk mencegah kontaminasi kotoran dan zat lain.

C. Penandaan

1) Semua larutan, filtrat dan endapan yang dianalisis diberi label secara sistematis (Label dibawa sendiri oleh mahasiswa).

2) Jika bejana berisi cairan selain air maka diberi tanda selama analisis dilakukan.

d. Perencanaan

1) Sebelum melakukan praktikum, mahasiswa memahami petunjuk cara kerja dan prinsip penetapan kadar. Alat dan pereaksi yang akan digunakan disiapkan. Hal apa yang harus dikerjakan utama direncanakan terlebih dahulu sehingga 
pekerjaan akan dapat berjalan dengan lancar.

2) Sampel jangan dipanaskan dengan alat gelas yang berskala karena gelasnya akan memuai dan jika kembali dingin maka volumenya belum tentu kembali dengan sempurna.

e. Penetapan dalam triplo

Penetapan paling sedikit dilakukan sebanyak tiga kali. Jika digunakan volume larutan sama, pembacaan buret tidak boleh berselisih lebih dari 0,3 $\mathrm{mL}$. Jika syarat- syarat ini tidak tercapai maka dilakukan titrasi lagi sampai diperoleh selisih yang tidak lebih dari 0,3 $\mathrm{mL}$.

\section{f. Pencatatan}

Hal-hal yang perlu dimasukkan dalam catatan:

1) Nama, jenis, dan sifat sampel

2) Tanggal analisis

3) Semua data numerik, misalnya volume larutan, bobot sampel, normalitas, volume titran.

4) Suhu pemanasan

5) Perhitungan, hasil dan lain-lain yang berkaitan dengan pengamatan.

g. Penimbangan

1)

Zat yang akan ditimbang diambil dengan menggunakan sendok zat.

2) Timbangan yang akan digunakan dipilih timbangan yang sesuai dengan kapasitas zat yang akan ditimbang. Menimbang zat jangan melebihi kapasitas timbangan. Hasil penimbangan dicatat.

3)

Jumlah zat yang harus ditimbang atau diukur tidak boleh kurang dari $90 \%$ dan tidak boleh lebih dari $110 \%$ dari jumlah yang tertera. 
4) Pengukuran dilakukan dengan pipet volume atau maat yang memenuhi syarat.

h. Cara menyatakan hasil

Adakalanya diantara hasil yang diperoleh dari seri pengukuran terdapat hasil yang sangat menyimpang bila dibandingkan dengan yang lain. Sehingga perlu dilakukan analisis data secara statistik untuk mengetahui apakah harga itu ditolak atau diterima.

Sebagai contoh: pada penetapan kadar $\mathrm{NaCl}$ diperoleh harga-harga 98,72\%; 98,81\%; 98,83\%; 98,92\%; dan 95,18\%. Jika diperhatikan harga $95,18 \%$ paling menyimpang dari hasil pengukuran yang lain, maka harga ini perlu dicurigai tidak dimasukkan. Hasil yang menyimpang ini disebut dengan outlier. Jadi reratanya:

$$
\bar{x}=\frac{(95,72+95,81+95,83+95,92)}{4}=95,82
$$

\begin{tabular}{|c|c|c|c|}
\hline $\mathbf{X}$ & $\bar{X}$ & $d=(\bar{X}-x)$ & $\mathbf{d}^{2}$ \\
\cline { 1 - 2 } & \multirow{3}{*}{95,72} & $-0,10$ & 0,0100 \\
\cline { 4 - 4 } & & $-0,01$ & 0,0001 \\
\hline 95,81 & & $+0,01$ & 0,0001 \\
\hline 95,83 & & $+0,01$ & 0,0100 \\
\hline 95,92 & & $\sum \mathrm{d}=0,22$ & $\sum \mathrm{d}^{2}=0,0202$ \\
\hline
\end{tabular}


Deviasi rata-rata $(\bar{d})$ :

$\bar{d}=\frac{\sum|\bar{x}-x|}{N}$

Standar Deviasi (SD) :

$\mathrm{SD}=\sqrt{\frac{\sum(\bar{X}-X)^{2}}{(N-1)}}$

Standar Deviasi Relative (SDR)/Koefisien yariasi (CV)

Standar Deviasi Relative/koefisien variasi $=\frac{\mathrm{SD}}{\bar{X}} \times 100 \%$

$\bar{d}=\frac{a .22}{4}=0,055$

$\mathrm{SD}=\sqrt{\frac{0,0202}{3}}=0,08$

i. Cara penulisan angka

Penulisan angka hasil analisis atau hasil pengukuran pada hakikatnya berkaitan dengan ketelitian alat yang digunakan. Angka penting adalah semua angka dalam suatu bilangan yang dapat diperoleh dari hasil pengukuran yang bersifat pasti dan satu yang mengandung suatu ketidakpastian (uncertain number).

1) Penulisan hasil pengukuran hanya terdapat satu angka yang harganya tak tentu yaitu angka terakhir. Misalnya suatu hasil penimbangan dituliskan dengan 1,0 dan $1,0000 \mathrm{~g}$, ini berarti bahwa ketelitian timbangan yang pertama hanya sampai 0,1 g. Jika penulisan dilakukan dengan 1,0000 g hal ini menunjukkan bahwa penimbangan dilakukan dengan 
neraca yang mempunyai ketelitian 0,1 mg dan hanya angka nol yang terakhir merupakan angka tidak tentu. Hasil penimbangan ini hanya dapat diperoleh jika menggunakan neraca analitik. Contoh lainnya: pembacaan buret makro dengan skala terkecil $0,1 \mathrm{ml}$ seharusnya dituliskan dua desimal misalnya 10,50 $\mathrm{ml}$ dan bukan $10,5 \mathrm{ml}$, sebab angka 5 belum pasti sehingga dapat diartikan volume titran berada antara 10,4 $\mathrm{ml}$ sampai $10,6 \mathrm{ml}$, padahal angka 5 yang menyatakan 0,5 $\mathrm{ml}$ dapat dibaca dengan pasti.

2) Dalam menuliskan hasil rata-rata pembacaan buret, banyaknya desimal disesuaikan dengan banyaknya desimal pada masing-masing pembacaan.

3) Banyaknya desimal hasil penjumlahan atau pengurangan sama dengan faktor penjumlahan atau pengurangan yang mengandung desimal paling sedikit. Contoh: 12,4 +121,502 $+3,6653=137,5673$. Hasil akhir cukup dituliskan 137,6. Dalam hal tertentu dapat dituliskan 137,57. Sedangkan banyaknya desimal hasil perkalian atau pembagian, sama dengan satu angka lebih banyak daripada yang terdapat pada faktor perkalian atau pembagian yang mengandung desimal paling sedikit. Contoh: $11,32 \times 12,2 \times 0,0321=$ 4,4331384. Hasil perkalian cukup dituliskan 4,43.

4) Pembulatan angka desimal, jika angka desimal 5 atau lebih dibulatkan ke atas sedangkan jika angka desimal kurang dari 5 dibulatkan ke bawah.

\subsection{Aplikasi Kimia Analisis}

Kimia Analisis dalam aplikasinya tidak hanya terbatas pada bidang ilmu Kimia saja, tetapi juga dapat diaplikasikan pada bidang ilmu yang lain. Contoh dalam bidang pertanian, farmasi, 
pencemaran lingkungan, geologi, biologi, kedokteran, mineralogi, kesehatan masyarakat, dan perindustrian. Contoh penerapan ilmu Kimia pada bidang pertanian yaitu dalam proses pembuatan pupuk misalnya pupuk NPK maka bahan baku yang digunakan yaitu urea, asam fosfat $\left(\mathrm{H}_{3} \mathrm{PO}_{4}\right)$, asam sulfat $\left(\mathrm{H}_{2} \mathrm{SO}_{4}\right)$, amoniak $\left(\mathrm{NH}_{3}\right), \mathrm{MgO}$, $\mathrm{ZnSO}_{4}$, dan $\mathrm{KCl}$. Pada bidang pencemaran lingkungan, bermanfaat untuk memantau kualitas air/udara. Pada bidang kedokteran penerapan ilmu Kimia yaitu pendeteksian senyawa/logam dalam tubuh (darah, urin, rambut, feses). Kemudian aplikasi ilmu Kimia pada bidang farmasi yaitu untuk memisahkan zat aktif tanaman yang dapat bermanfaat obat. Beberapa aplikasi ilmu Kimia Analisis lainnya tercantum dalam Tabel 1.1. 
Tabel 1.1 Beberapa Aplikasi Kimia Analisis

\begin{tabular}{|c|c|c|c|c|}
\hline SAMPEL & ANALIT & METODE & $\begin{array}{l}\text { BATAS } \\
\text { DETEKSI }\end{array}$ & PENGARUH \\
\hline Darah & Selenium & $\begin{array}{l}\text { HPLC dengan } \\
\text { deteksi fluoresensi }\end{array}$ & $0,15 \mathrm{mg}$ & $\begin{array}{l}\text { Se adalah unsur runut } \\
\text { (trace) utama dalam tubuh, } \\
\text { tetapi tingkat yang lebih } \\
\text { tinggi bersifat racun }\end{array}$ \\
\hline $\begin{array}{l}\mathrm{O}_{2} \\
\text { kemurnian } \\
\text { tinggi }\end{array}$ & $\mathrm{Ar}, \mathrm{N} 2, \mathrm{Kr}, \mathrm{CH}_{4}, \mathrm{Xe}$ & $\begin{array}{l}\text { GC dengan deteksi } \\
\text { fotoionisasi }\end{array}$ & $\begin{array}{l}0,01- \\
0,4 \mathrm{ppm}\end{array}$ & $\begin{array}{l}\text { O. yang sangat mumi } \\
\text { digunakan dalam } \\
\text { pembuatan semikonduktor }\end{array}$ \\
\hline Endapan & Tributiin (TBT) & Spektrometri massa & $\begin{array}{l}0,2 \mu \mathrm{g} \\
\text { Sn per } \\
\text { gram } \\
\text { sampel }\end{array}$ & $\begin{array}{l}\text { TBT bersifat racun } \\
\text { terhadap kerang laut }\end{array}$ \\
\hline $\begin{array}{l}\text { Larutan } \\
\text { berair }\end{array}$ & $\begin{array}{l}\text { Amfetamin sebagai } \\
\text { kation amfetaminium }\end{array}$ & $\begin{array}{l}\text { Potensiometri } \\
\text { dengan elektroda } \\
\text { selektif ion }\end{array}$ & $3 \mathrm{ppm}$ & $\begin{array}{l}\text { Amfetamin adalah zat } \\
\text { perangsang dalam sistem } \\
\text { saraf pusat }\end{array}$ \\
\hline $\begin{array}{l}\text { Air alami dan } \\
\text { jaringan } \\
\text { biologis }\end{array}$ & Timbel & $\begin{array}{l}\text { Spektrografi } \\
\text { absorpsi atom }\end{array}$ & $\begin{array}{l}1 \mathrm{pg} / \mathrm{mL} \\
\text { dalam air }\end{array}$ & $\begin{array}{l}\mathrm{Pb} \text { adalah bahan } \\
\text { pencemar lingkungan yang } \\
\text { beracun }\end{array}$ \\
\hline Air seni (urin) & $\begin{array}{l}\text { Poliamin seperti } \\
\text { putresin, kadaverin, } \\
\text { dan spermidin }\end{array}$ & $\begin{array}{l}\text { HPLC dengan } \\
\text { deteksi lunimesensi } \\
\text { kimiawi berdasarkan } \\
\text { oksidasi enzim yang } \\
\text { melepaskan } \mathrm{H}_{2} \mathrm{O}_{2}\end{array}$ & $\begin{array}{l}5 \mathrm{pmol} \\
\text { (putresin) }\end{array}$ & $\begin{array}{l}\text { Kadar poliamin dinaikkan } \\
\text { dalam pasien kanker } \\
\text { tertentu }\end{array}$ \\
\hline $\begin{array}{l}\text { Otot, hati dan } \\
\text { ginjal hewan } \\
\text { potong }\end{array}$ & Nitrcksinil & $\begin{array}{l}\text { HPLC dengan } \\
\text { deteksi spektrometri } \\
\text { massa }\end{array}$ & $\begin{array}{l}2 \text { mgig } \\
\text { jaringan }\end{array}$ & $\begin{array}{l}\text { Nitroksinil digunakan } \\
\text { dalam kedokteran hewan } \\
\text { untuk mengendalikan } \\
\text { cacing hati; kadar yang } \\
\text { dibolehkan dalam produk } \\
\text { daging tak boleh dilanggar }\end{array}$ \\
\hline Serum darah & Interieukin-2 (IL-2) & Immunoassay & $\begin{array}{l}100 \\
\text { pgimL }\end{array}$ & $\begin{array}{l}\text { IL-2 adalah faktor } \\
\text { pertumbuhan bagi sel-sel } \\
\text { tertentu dalam sistem } \\
\text { kekebalan; zat ini } \\
\text { menjalani evaluasi untuk } \\
\text { digunakan dalam } \\
\text { pengobatan penyakit AIDS } \\
\text { dan cancer }\end{array}$ \\
\hline $\begin{array}{l}\text { Sayuran dan } \\
\text { tumbuhan }\end{array}$ & $\begin{array}{l}\text { Arsenik dan } \\
\text { selenium }\end{array}$ & $\begin{array}{l}\text { Spektroskopi } \\
\text { fluoresensi sinar-X }\end{array}$ & $0,1 \mu \mathrm{g}$ & $\begin{array}{l}\text { Abu dari pabrik yang } \\
\text { digunakan sebagai pupuk } \\
\text { buatan mengandung As } \\
\text { dan Se yang dapat } \\
\text { terbawa dalam rantai } \\
\text { makanan }\end{array}$ \\
\hline Urin & Metadon & Voltametri & $\begin{array}{l}0,3 \mu \\
g / m L\end{array}$ & $\begin{array}{l}\text { Metadon adalah analgesik } \\
\text { narkotik yang digunakan } \\
\text { dalam pengobatan } \\
\text { pecandu heroin dan mortin }\end{array}$ \\
\hline
\end{tabular}

Sumber: Day \& Underwood, 1998. 


\subsection{Rangkuman}

> Kimia Analisis merupakan salah satu cabang ilmu Kimia yang mempelajari tentang pemisahan (separasi), identifikasi, determinasi/menganalisis komponen kimia dalam suatu bahan baik bahan alam maupun bahan buatan

$>$ Kimia analisis menurut tujuannya dibedakan menjadi kimia analisis kualitatif, kuantitatif, dan struktur. Berdasarkan senyawa yang dianalisis dibedakan menjadi dua yaitu senyawa organik dan anorganik. Berdasarkan metode, dibedakan menjadi dua yaitu analisis konvensional (klasik) dan modern.

$>$ Beberapa teknik analisis kualitatif yaitu:teknik menyaring, mencuci endapan pada kertas saring, melarutkan endapan dan pengenceran.

$>$ Teknik dasar yang perlu diketahui oleh mahasiswa ketika melakukan teknik analisis kuantitatif yaitu kebersihan, kerapian, penandaan (pelabelan), perencanaan, penetapan dalam triplo, pencatatan, penimbangan, cara menyatakan hasil, dan cara penulisan angka.

> Aplikasi Kimia Analisis yaitu dalam bidang kimia, pertanian, farmasi, pencemaran lingkungan, geologi, 
biologi, kedokteran, mineralogi, kesehatan masyarakat, dan perindustrian.

\subsection{Latihan Soal}

Sebagai sarana Anda dalam memahami materi Pengantar

Kimia Analisis, jawablah soal di bawah ini secara sistematis!

1. Apa yang Anda ketahui tentang Kimia Analisis?

2. Sebutkan dan jelaskan perbedaan Kimia Analisis Kualitatif dan kuantitatif! Beri contoh!

3. Mengapa prinsip dalam analisis kuantitatif itu penting?

4. Jelaskan penggolongan kimia Analisis berdasarkan berbagai aspek!

5. Sebutkan aplikasi Kimia Analisis pada kehidupan sehari-hari! 


\section{BAB 2}

\section{DASAR-DASAR KIMIA ANALISIS}

\begin{tabular}{|l|}
\hline \multicolumn{2}{|c|}{ Sub-Capaian Pembelajaran Mata Kuliah } \\
\hline 1. Mahasiswa mampu memahami konsep dasar-dasar \\
analisis. \\
2. Mahasiswa mampu menjelaskan dan memahami reaksi- \\
reaksi dasar analisis. \\
3. Mahasiswa mampu menjelaskan dan memahami konsep \\
hubungan gram, mol, dan gram ekivalen. \\
4. Mahasiswa mampu melakukan preparasi larutan standar. \\
5. Mahasiswa mampu memahami analisis titrimetri baik \\
proses asidi-alkalimetri, argentometri, \\
kompleksometri, reduksi dan oksidasi, serta analisis gas- \\
gas. \\
6. Mahasiswa mampu memahami konsep dan menerapkan \\
prosedur analisis kuantitatif dalam pendekatan analisis \\
instrumental: kolorimetri.
\end{tabular}

\subsection{Reaksi-Reaksi Dasar Analisis}

Reaksi dasar dari suatu analisis digolongkan berdasarkan jenis reaksi yang terjadi antara larutan yang ada di dalam erlenmeyer (analit) dengan larutan yang ada di dalam biuret (titran).

\section{a. Titrasi Netralisasi, terdiri dari :}

- Asidimetri 
Merupakan titrasi yang melibatkan antara larutan basa kuat, basa lemah atau garam terhidrolisis yang berasal dari reaksi antara asam lemah dengan larutan standar asam kuat. Reaksinya yaitu :

$$
\mathrm{NH}_{4} \mathrm{OH}_{(a q)}+\mathrm{HCl}_{(a q)} \rightarrow \quad \mathrm{NH}_{4} \mathrm{Cl}_{(a q)}+\mathrm{H}_{2} \mathrm{O}_{(l)}
$$

- Alkalimetri

Merupakan titrasi yang melibatkan larutan yang bersifat asam kuat, asam lemah atau garam terhidrolisis yang berasal dari reaksi antara basa lemah dengan larutan standar basa kuat. Reaksinya yaitu :

$$
\mathrm{CH}_{3} \mathrm{COOH}_{(a q)}+\mathrm{NaOH}_{(a q)} \rightarrow \mathrm{CH}_{3} \mathrm{COONa}(a q)+\mathrm{H}_{2} \mathrm{O}_{(l)}
$$

\section{b. Titrasi Pengendapan}

Yaitu titrasi yang menghasilkan endapan yang tidak mudah larut antara titran dan analit. Titrasi yang menghasilkan endapan ini banyak digunakan untuk pengendapan antara kation perak dengan anion halogen, sehingga titrasi ini juga bisa disebut dengan titrasi argentometri. Reaksi yang terjadi :

$$
\mathrm{Cl}_{(a q)}^{-}+\mathrm{Ag}_{(a q)}^{+} \rightarrow \mathrm{AgCl}_{(s)}
$$

\section{c. Titrasi Pembemtukan Kompleks}

Yaitu proses dari titrasi yang menyebabkan terbentuknya senyawa atau ion yang kompleks dan stabil. Sebagai contoh dari titrasi ini yaitu titrasi antara ion perak dengan ion sianida yang menghasilkan ion kompleks berupa $\mathrm{Ag}(\mathrm{CN})_{2}$. Reaksinya yaitu :

$$
\mathrm{Ag}_{(a q)}^{+}+\mathrm{CN}_{(a q)} \quad \rightarrow A g\left[\mathrm{Ag}(\mathrm{CN})_{2}\right]_{(s)}
$$

\section{d. Titrasi Reduksi Oksidasi (Redoks)}


Yaitu proses dari suatu titrasi yang akan menimbulkan perubahan bilangan oksidasi atau valensi dari zat-zat yang akan bereaksi. Contoh dari titrasi redoks ini yaitu titrasi antara besi(II) yang dioksidasi dengan serium(IV) yang akan menjadi besi(III) dan serium(III). Reaksi yang terjadi yaitu :

\subsection{Konsentrasi Larutan}

$$
\mathrm{Fe}^{2+}{ }_{(a q)}+\mathrm{Ce}^{4+}{ }_{(a q)} \rightarrow \mathrm{Fe}^{3+}{ }_{(a q)}+\mathrm{Ce}^{3+}{ }_{(a q)}
$$

\section{a. Molaritas (M)}

Molaritas didefinisikan sebagai jumlah mol zat terlarut dalam satu liter larutan. Rumus molaritas yaitu:

$$
\text { Molaritas }(M)=\frac{\text { mol zat terlarut }}{\text { liter larutan }}=\frac{n}{V}=\frac{g}{M r \times V}
$$

Jika volume yang digunakan dalam satuan $\mathrm{mL}$ maka:

$$
\text { Molaritas }(M)=\frac{g}{M r} \times \frac{1000}{V}
$$

\section{b. Normalitas (N)}

Normalitas didefinisikan sebagai jumlah ekivalen zat terlarut per liter larutan. Karena ekivalen (eq) adalah gram zar terlarut dibagi berat ekivalen (BE) maka:

Normalitas $(N)=\frac{e q}{V}=\frac{g}{B E \times V}$

Jika volume yang digunakan dalam satuan $\mathrm{mL}$ maka:

$$
\text { Normalitas }(N)=\frac{g}{B E} \times \frac{1000}{V}
$$

Berat ekivalen (BE) dari suatu asam atau basa didefinisikan sebagai berat yang diperlukan dalam gram 
untuk bereaksi dengan $1 \mathrm{~mol} \mathrm{H}^{+}$. Satu miliekivalen (meq) adalah seperseribu dari satu ekivalen $(1000 \mathrm{meq}=1 \mathrm{eq})$. Hubungan antara $\mathrm{M}_{\mathrm{r}}$ dengan $\mathrm{BE}$ adalah:

$$
B E=\frac{M r}{n}
$$

Dengan $\mathrm{n}$ adalah jumlah mol $\mathrm{H}^{+}$asam atau yang direaksikan dengan 1 mol basa. Untuk reaksi oksidasi reduksi, berat ekivalen didefinisikan sebagai berat (dalam gram) yang diperlukan untuk bereaksi dengan 1 mol elektron. Sedangkan untuk pengendapan dan pembentukan kompleks, berat ekivalen didefinisikan sebagai berat (dalam gram) yang diperlukan untuk bereaksi dengan 1 mol kation univalen, $1 / 2 \mathrm{~mol}$ kation divalen, 1/3 mol kation trivalen dan sebagainya.

Hubungan antara normalitas dan molaritas adalah: $\mathrm{N}=\mathrm{n} \mathrm{x}$ M

Di mana $\mathrm{n}$ adalah jumlah mol ion hidrogen, elektron atau kation univalen yang bereaksi.

\section{c. Formalitas (F)}

Formalitas didefinisikan sebagai jumlah dari berat rumus per liter larutan. Rumus formalitas yaitu:

$$
\text { Formalitas }(F)=\frac{n_{f}}{B R}=\frac{g}{B R \times V}
$$

Berat rumus biasanya sinonim dengan berat molekul. Oleh karena itu biasanya formalitas sama dengan molaritas.

\section{d. Molalitas (m)}

Molalitas didefinisikan sebagai jumlah mol zat terlarut per kilogram pelarut. Rumus molalitas yaitu: 
$\operatorname{Molalitas}(m)=\frac{\text { mol zat terlarut }}{k g \text { pelarut }}=\frac{n}{p}=\frac{g}{\operatorname{Mr} \times p}$

Jika volume yang digunakan dalam satuan $\mathrm{mL}$ maka:

Molalitas $(m)=\frac{g}{M r} x \frac{1000}{p}$

dengan $\mathrm{p}$ adalah berat pelarut dalam satuan $\mathrm{kg}$ atau $\mathrm{g}$

\section{e. Prosentase Zat}

Persentase zat dalam larutan biasanya dinyatakan sebagai persen berat $(\% \mathrm{~b} / \mathrm{b})$ yang didefinisikan sebagai jumlah dari gram zat terlarut per 100 gram larutan. Dengan rumus sebagai berikut:

$$
\begin{gathered}
\text { persen berat }=\frac{\text { massa zat }}{\text { massa total }} \times 100 \\
\text { atau } \\
\text { persen berat }=\frac{m_{A}}{m_{A}+m_{R}} \times 100
\end{gathered}
$$

Satuan persen lainnya adalah persen volume $(\% \mathrm{v} / \mathrm{v})$ dan persen berat- volume (persen $\mathrm{b} / \mathrm{v}$ ).

$$
\begin{gathered}
\text { persen volume }=\frac{\text { volume zat }}{\text { volume total }} \times 100 \\
\text { persen berat }=\frac{\text { massa zat }(\text { dalam gram })}{\text { volume total }(\text { dalam } m L)} \times 100
\end{gathered}
$$

\section{f. Bagian per sejuta (ppm)}


Jumlah bagian suatu larutan dalam 1 juta bagian larutan, secara matematis dinyatakan sebagai:

$$
p p m=\frac{m}{m+m_{0}} \times 10^{6}
$$

di mana $\mathrm{m}$ adalah jumlah gram zat terlarut dan $\mathrm{m}_{0}$ adalah jumlah gram zat pelarut karena m biasanya amat kecil dibandingkan $\mathrm{m}_{0}$ maka:

$$
\text { ppm }=\frac{m}{m_{0}} \times 10^{6}
$$

Selain ppm ada juga ppb yaitu bagian per semilyar.

\subsection{Hubungan Gram, Mol dan Gram Ekivalen}

Besaran dari ekivalen memiliki harga yang berbedabeda terhadap jenis reaksinya. Konfirmasi terhadap reaksi tersebut harus diperoleh sebelum dilakukannya penghitungan konversi besaran tersebut. Mengetahui perhitungan tersebut akan sangat membantu dalam penyiapan suatu larutan standar dan hitungan-hitungan tersebut termasuk dalam analisis volumetri.

\section{a. Reaksi netralisasi}

Ekivalen suatu asam merupakan jumlah massa yang bersifat asam yang memiliki kandungan 1,0078 gram hidrogen yang dapat pula digantikan oleh atom yang lain. Contoh dari ekivalen asam monoprotik yaitu $\mathrm{HCl}, \mathrm{HBr}$, $\mathrm{HNO}_{3}$. Asam-asam tersebut memiliki jumlah mol yang bersifat asam, sehingga satu normal larutan asam monoprotik memiliki kandungan $1 \mathrm{~mol} / \mathrm{L}$ larutan. Sedangkan untuk ekivalen asam diprotik dan triprotik sama dengan $1 / 2$ dan $1 / 3$ mol. Larutan satu normal yaitu larutan yang memiliki kandungan 1 ekivalen zat per liter yang menggunakan konsep ekivalen. 
Ekivalen suatu basa merupakan jumlah massa yang bersifat basa yang mengandung 1 gugus hidroksil yang memiliki kandungan sebesar 17,008 gram hidroksil yang dapat digantikan dengan atom atau gugus lain. Ekivalen natrium hidroksida memiliki jumlah mol yang sama dan kalsium hidroksida memiliki mol yang sama yaitu sebesar $1 / 2$ mol. Akibat pengaruh dari reaksi hidrolisis, garam-garam yang berasal dari basa kuat dan asam lemah mengalami reaksi alkalin. Dalam satu mol natrium karbonat akan bereaksi dengan asam klorida yang memiliki jumlah mol 2 dan akan membentuk 2 mol natrium klorida, sehingga dalam satu ekivalen gram ini memiliki mol yang sama yaitu $1 / 2 \mathrm{~mol}$.

\section{b. Reaksi Pengendapan dan Pembentukan Senyawa Kompleks}

Ekivalen dari suatu zat yaitu massa suatu zat yang mengandung atau yang bereaksi dengan 1 mol kation univalen $\mathrm{M}^{+}$atau ekivalen yang mengandung 1,0078 gram hidrogen. Sedangkan kation divalen $\mathrm{M}^{2+}$ mengandung $1 / 2$ mol dan kation trivalen $\mathrm{M}^{3+}$ memiliki kandungan $1 / 3$ mol dan seterusnya. Untuk kation, ekivalen $=$ mol dibagi valensi. Ekivalen suatu reagen yaitu reagen yang bereaksi dengan kation merupakan massa zat yang akan bereaksi dengan 1 ekivalen kation. Ekivalen suatu garam, dalam reaksi pengendapan merupakan jumlah mol garam dibagi dengan total valensi ion-ion yang akan berekasi. Ekivalen dari larutan perak nitrat dalam titrasi oleh ion klorida setara dengan $1 \mathrm{~mol}$

\section{c. Reaksi Oksidasi-Reduksi (Redoks)}

Banyaknya massa suatu zat yang bereaksi atau mengandung 1,0078 gram hidrogen atau 8,000 gram oksigen $\left(\begin{array}{lll}1 / 2 & \text { mol } & \mathrm{O}_{2}\end{array}\right)$ merupakan ekivalen dari suatu agen yang mengoksidasi atau mereduksi zat tersebut. Jumlah dari 
oksigen yang terdapat tersebut ditentukan dengan cara persamaan hipotetik. Misalnya, reaksi hipotetik dari larutan $\mathrm{KMnO}_{4}$ :

\section{$2 \mathrm{KMnO}_{4} \rightarrow \mathrm{K}_{2} \mathrm{O}+\mathrm{MnO}+5 \mathrm{O}$}

Berdasarkan persamaan tersebut dapat diketahui bahwa dalam suasana asam, $2 \mathrm{KMnO}_{4}$ menghasilkan 5 atom oksigen yang dapat di tangkap oleh suatu agen pereduksi, sehingga ekivalen $\mathrm{KMnO}_{4}=1 / 5 \mathrm{~mol}$.

Metode lain yaitu dengan cara memperhatikan jumlah elektron yang dilepaskan oleh zat dalam proses suatu reaksi serta adanya perubahan bilangan dari oksidasi unsur utama agen pereduksi atau pengoksidasi. Pada metode kedua, satu ekivalen zat merupakan jumlah dari mol zat yang menerima (oksidasi) atau melepaskan (reduktor) dari sebuah elektron. $\mathrm{KMnO}_{4}$ dalam suasana yang bersifat asam dapat menangkap 5 elektron, maka 1 ekivalen $\mathrm{KMnO}_{4}$ setara dengan $1 / 5 \mathrm{~mol}$.

Metode ketiga yaitu adanya perubahan bilangan oksidasi. Satu ekivalen zat merupakan banyaknya jumlah mol suatu zat yang mengalami perubahan satu satuan bilangan oksidasi. Sebagai contoh, pada reduksi $\mathrm{K}_{2} \mathrm{Cr}_{2} \mathrm{O}_{7}$ terjadi perubahan menjadi $2 \mathrm{Cr}^{3+}$ bilangan oksidasi $\mathrm{Cr}$ mengalami perubahan menjadi 6 satuan, sehingga dalam satu ekivalen $\mathrm{K}_{2} \mathrm{Cr}_{2} \mathrm{O}_{7}=1 / 6$ mol.

Konsep-konsep di atas dapat dipelajari dan akan sangat membantu dalam pembuatan dari suatu larutan standar, sehingga memudahkan dan mempercepat perhitungan dalam titrasi analisis volumetri.

\subsection{Preparasi Larutan Standar}

Larutan standar merupakan istilah kimia yang dapat diartikan dengan larutan yang telah diketahui konsentrasinya dengan akurat dan tepat. Larutan standar ini dapat dinyatakan 
dengan satuan $\mathrm{N}$ (normalitas) atau $\mathrm{M}$ (molaritas). Larutan standar dibagi menjadi 2 macam, yaitu :

\section{a. Larutan Standar Primer}

Merupakan larutan standar yang konsentrasinya telah diketahui kemurniannya dengan pasti, konsentrasi didapatkan dengan cara penimbangan. Syarat-syarat senyawa yang dapat dijadikan larutan standar primer yaitu sebagai berikut :

$\checkmark$ Memiliki kemurnian yang tinggi yaitu sekitar 100\%

$\checkmark$ Memiliki sifat yang stabil pada suhu kamar dalam kata lain zat tidak boleh higroskopik serta tidak boleh dioksidasi oleh udara

$\checkmark$ Bersifat stabil pada suhu pemanasan(pengeringan). Hal tersebut umumnya senyawa primer dipanaskan terlebih dahulu sebelum ditimbang

$\checkmark$ Zat tersebut mudah diperoleh (dijumpai dibeberapa tempat)

$\checkmark$ Memiliki massa molekul relatif yang tinggi (Mr). Hal tersebut untuk meminimalisir kesalahan relatif yang terjadi pada saat menimbangan dilakukan. Penimbangan dengan massa molekul relatif yang tinggi(besar) akan lebih mudah dilakukan dan memiliki tingkat kesalahan yang rendah(kecil) dibandingkan dengan penimbangan dengan massa molekul yang rendah(kecil).

$\checkmark$ Zat tersebut harus mudah larut dalam pelarut yang dipilih

Contoh dari larutan standar primer yaitu: $\mathrm{As}_{2} \mathrm{O}_{3}$, $\mathrm{KBrO}_{3}, \mathrm{Na}_{2} \mathrm{CO}_{3}, \mathrm{KHC}_{8} \mathrm{H}_{4} \mathrm{O}_{4}, \mathrm{NaCl}, \mathrm{K}_{2} \mathrm{Cr}_{2} \mathrm{O}_{7}$, asam oksalat serta asam benzoat 


\section{b. Larutan Standar Sekunder}

Merupakan zat yang belum diketahui konsentrasinya dengan pasti, konsentrasi larutan dapat diketahui melalui proses standarisasi, proses standarisasi ini diperoleh dengan cara menitrasi larutan tersebut dengan larutan standar primer. Syarat-syarat dari senyawa yang dapat dijadikan sebagai standar sekunder yaitu, sebagai berikut :

$\checkmark$ Memiliki derajat kemurnian yang rendah dibandingkan dengan larutan standar primer

$\checkmark$ Untuk memperkecil kesalahan dalam menimbang, zat harus memiliki berat ekivalen yang besar(tinggi)

$\checkmark$ Larutan harus stabil dalam penyimpanan Contoh dari larutan standar sekunder yaitu : $\mathrm{AgNO}_{3}$, $\mathrm{KMnO}_{4}$ dan $\mathrm{Fe}\left(\mathrm{SO}_{4}\right)$

Larutan standar dapat dibuat dengan mengencerkan suatu larutan pekat yang sebelumnya telah diketahui konsentrasinya atau mengencerkan zat murni yang konsentrasinya belum diketahui. Melakukan pengenceran dari suatu larutan pekat yang telah diketahui konsentrasinya dilakukan dengan perhitungan antara pengenceran dengan persamaan, yaitu :

$$
V_{1} \cdot N_{1}=V_{2} \cdot N_{2}
$$

Diketahui : $\quad V_{1}=$ volume larutan pekat

$$
\begin{aligned}
& V_{2}=\text { volume setelah dilakukan pemngenceran } \\
& N_{1}=\text { nilai normalitas dari larutan pekat }
\end{aligned}
$$




$$
N_{2}=\text { normalitas setelah pengenceran }
$$

Sedangkan apabila konsentrasi dari larutan belum diketahui, maka pembuatan larutan dengan normalitas tertentu perlu digunakan data kerapatan dan kadar dari zat tersebut. Misalkan kerapan cairan, $\mathrm{L}$ g/mL jadi setiap $1 \mathrm{~mL}$ cairan mengandung berat $\mathrm{L}$ gram. Cairan yang memiliki kadar $\mathrm{K} \%$ berat, maka setiap 100 gram cairan memiliki kandungan zat murni sebesar $\mathrm{K}$ gram. Berarti setiap $1 \mathrm{~mL}$ cairan memiliki kandungan zat murni (L/100) K gram atau sama dengan (L . K / 100) gram, maka untuk x mL cairan mengandung zat murni sebanyak x . L . K / 100 gram atau sama dengan :

$$
\begin{aligned}
& 10 \cdot \mathrm{X} \cdot \mathrm{K} \cdot \mathrm{L} \text { mgram } \\
& =\frac{10 \cdot x \cdot K \cdot L}{M r} \mathrm{mmol}
\end{aligned}
$$

Tetapi jika zat bervalensi n maka jumlah rumus di atas sama dengan

$$
\frac{10 \cdot x \cdot K \cdot L \cdot n}{M r} \text { mgrek }
$$

Sedangkan untuk pembuatan larutan dengan satuan $\mathrm{N}$ (normalitas), harus mengandung $\mathrm{N}$ grek zat terlarut dalam setiap $1 \mathrm{~L}$ larutan dan setiap volume $(\mathrm{V}) \mathrm{mL}$ larutan $\mathrm{N}$ mengandung V.N mgrek. Berarti :

$$
\frac{10 \cdot x \cdot K \cdot L \cdot n}{M r}=\mathrm{N} . \mathrm{V}
$$

Sehingga,

$$
\mathrm{X}=\frac{N \cdot V \cdot M r}{10 \cdot n \cdot K \cdot L} \mathrm{~mL}
$$


Apabila reagen dalam kondisi yang tidak murni, maka larutan standar dilakukan standarisasi dengan larutan standar primer.

\subsection{Rangkuman}

> Reaksi-reaksi dasar analisis meliputi reaksi netralisasi, pengendapan, pembentukan kompleks, dan reduksi oksidasi (redoks)

$>$ Konsentrasi larutan meliputi molaritas, normalitas, formalitas, molalitas, prosentase zat, dan bagian per sejuta (ppm).

$>$ Besaran dari ekivalen memiliki harga yang berbedabeda terhadap jenis reaksinya. Konfirmasi terhadap reaksi tersebut harus diperoleh sebelum dilakukannya penghitungan konversi besaran tersebut. Mengetahui perhitungan tersebut akan sangat membantu dalam penyiapan suatu larutan standar dan hitungan-hitungan tersebut termasuk dalam analisis volumetri.

$>$ Larutan standar terdiri dari larutan standar primer dan sekunder

\subsection{Contoh dan Latihan Soal}

\section{Contoh soal 1.}

Hitunglah molaritas $\mathrm{NaOH}$ yang dibuat dengan melarutkan 2,5 gram $\mathrm{NaOH}$ dalam $250 \mathrm{~mL}$ air.

Penyelesaian:

$$
\begin{aligned}
\text { Molaritas (M) } & =\frac{g}{M r} \times \frac{1000}{V} \\
& =\frac{2,5 g}{40 \mathrm{~g} / \mathrm{mol}} \times \frac{1000}{250 \mathrm{~mL}}=0,25 \mathrm{M}
\end{aligned}
$$




\section{Contoh soal 2.}

Berapa gram natrium klorida yang dibutuhkan untuk membuat $100 \mathrm{~mL}$ larutan dengan konsentrasi 0,01 N.

Penyelesaian:

$$
\begin{array}{r}
\text { Normalitas }(N)=\frac{g}{B E} x \frac{1000}{V} \\
\mathrm{NaCl} \rightarrow \mathrm{Na}^{+}+\mathrm{Cl}^{-} \\
\mathrm{Na}^{+}+\mathrm{H}^{+} \rightarrow \mathrm{NaOH} \\
\mathrm{Cl}^{-}+\mathrm{H}^{+} \rightarrow \mathrm{HCl}
\end{array}
$$

Sehingga jumlah $\mathrm{n}$ dari $\mathrm{NaCl}$ yaitu 1, maka $B E=\frac{M r}{n}=\frac{58,5}{1}=58,5$. Maka gram natrium klorida yang dibutuhkan yaitu:

$$
\begin{gathered}
\text { Normalitas }(N)=\frac{g}{B E} \times \frac{1000}{V} \\
0,01 \mathrm{~N}=\frac{g}{58,5} \times \frac{1000}{100} \\
58,5=g \times 1000 \\
g=\frac{58,5}{1000}=0,0585 \text { gram }
\end{gathered}
$$

\section{Latihan soal:}

Kerjakan soal di bawah ini!

1. Apa yang Anda ketahui tentang dasar-dasar analisis.

2. Sebutkan dan jelaskan jenis-jenis reaksi dasar dalam Kimia Analisis.

3. Berapakah normalitas larutan $\mathrm{Ba}(\mathrm{OH})^{2}$ 0,0123 $\mathrm{M}$ yang bereaksi dengan $\mathrm{HCl}$ sesuai dengan persamaan reaksi $\mathrm{Ba}(\mathrm{OH})^{2}+2 \mathrm{HCl} \rightarrow \mathrm{BaCl}^{2}+2 \mathrm{H}^{2} \mathrm{O}$

4. Persen berat $\mathrm{HCl}$ pekat adalah $32,0 \%$ dengan kerapatan $1,18 \mathrm{~g} / \mathrm{mL}$. Berapakah molaritas $\mathrm{HCl}$ tersebut.

5. Hitung formalitas larutan yang dibuat dengan 
melarutkan 110,0 mg $\mathrm{K}^{2} \mathrm{Cr}^{2} \mathrm{O}^{7}$ dalam $100 \mathrm{~mL}$ air. Larutan tersebut akan digunakan untuk mengoksidasi fero klorida sesuai dengan persamaan berikut: $\mathrm{K}_{2}^{2} \mathrm{Cr}_{2} \mathrm{O}^{7}+\mathrm{FeCl}_{2}+\mathrm{HCl} \rightarrow \mathrm{CrCl}^{3}+\mathrm{FeCl}^{3}+\mathrm{KCl}+\mathrm{H}_{2} \mathrm{O}$ 


\section{BAB 3}

\section{TITRASI ASIDI-ALKALIMETRI}

\begin{tabular}{|c|c|}
\hline \multicolumn{2}{|r|}{ Sub-Capaian Pembelajaran Mata Kuliah } \\
\hline 1. & $\begin{array}{l}\text { Mahasiswa } \\
\text { mampu menjelaskan reaksi asam-basa dan definisi titrasi } \\
\text { asidi-alkalimetri dengan memberikan contoh dan } \\
\text { menuliskan persamaan reaksinya. }\end{array}$ \\
\hline 2. & $\begin{array}{l}\text { Mahasiswa } \\
\text { mampu melakukan titrasi asidi-alkalimetri dan menentukan } \\
\text { titik akhir dari kurva titrasi. }\end{array}$ \\
\hline 3. & mampu membedakan reaksi asam-basa. \\
\hline 4. & $\begin{array}{l}\text { mampu menjelaskan hubungan gram mol dan gram } \\
\text { ekivalen. }\end{array}$ \\
\hline
\end{tabular}

\subsection{Reaksi Asam Basa}

Istilah asam berasal dari bahasa latin yaitu acidus (asam), yang berkaitan dengan kata acer (tajam) dan acetum (cuka). Cuka merupakan larutan dari asam asetat. Dan untuk istilah alkali (basa) berasal dari bahasa Arab yaitu al-qali yang berarti abu dari suatu tanaman yang ada kaitannya dengan daerah rawa garam dan padang pasir. Sumber dari kata basa yaitu abu hasil pembakaran kayu. Sudah sejak lama diketahui bahwa asam dan basa dapat saling menetralkan dan dapat membentuk senyawa berupa garam dan air. Sifat yang berkaitan dengan asam yaitu rasanya yang asam, rasa 
seperti tertusuk jarum apabila terkena kulit. Kemampuan yang dimiliki asam yaitu, dapat melarutkan sebagian besar dari logam, dapat melarutkan batu kapur dan mineral karbonat lainnya. Sedangkan basa memiliki rasa pahit dan licin. Sifat dasar dari basa ini yaitu banyak ditemukan pada sabun dan zat pembersih peralatan rumah tangga lainnya. Baik asam maupun basa memiliki kemampuan untuk mempengaruhi warna dari unsur pokok tanaman tertentu. Misalnya, lakmus berasal dari sebangsa tumbuhan lumut. Dalam larutan asam lakmus ini akan berwarna mmerah dan lakmus akan tetap berwarna biru jika dalam larutan yang bersifat basa. Terdapat beberapa teori yang mencoba menjelaskan tentang asam basa diantaranya yaitu :

Antoine Lavoisier (1777). Mengemukakan bahwa semua dari asam mengandung $\mathrm{O}_{2}$ (oksigen).

Humphry Davy(1810). Mengemukakan bahwa unsur dalam asam bukan oksigen tetapi hidrogen, yang ditunjukkan oleh asam hidrokhlorik yang mengandung hanya atom $\mathrm{H}$ dan $\mathrm{Cl}$ tanpa ada $\mathrm{O}$.

Svante Arrhenius(1884). Berdasarkan teori tentang penguraian elektrolisis, bahwa terdapat dua macam larutan elektrolit (larutan dalam air). Dua macam larutan elektrolit tersebut yaitu elektrolit kuat dan elektrolit lemah. Disebut dengan elektrolit kuat apabila zat tersebut terlarut terurai sempurna (terionisasi) di dalam air, sedangkan apabila disebut dengan elektrolit lemah jika hanya sedikit sekali senyawa yang terionisasi. Menurut Arrhenius, asam merupakan senyawa yang jika terurai akan menghasilkan ion hidrogen $\left(\mathrm{H}^{+}\right)$. Contohnya :

$$
\mathrm{HCl}_{(a q)} \rightarrow \mathrm{H}_{(a q)}^{+}+\mathrm{Cl}_{(a q)}^{-}
$$


Sedangkan basa merupakan senyawa yang jika terdisosiasi menghasilkan ion $\mathrm{OH}^{-}$, contohnya :

$$
\mathrm{NaOH}_{(a q)} \rightarrow \mathrm{Na}_{(a q)}^{+}+\mathrm{OH}_{(a q)}^{-}
$$

Reaksi yang terjadi antara larutan asam dan basa disebut dengan reaksi netralisasi serta dapat dinyatakan dengan persamaan ionik, sebagai berikut :

$$
\frac{\mathrm{H}_{(a q))}^{+} \mathrm{Cl}_{(\text {aq) }}^{-}}{\text {asam }}+\frac{\mathrm{Na}_{(\text {aq })}^{+}+\mathrm{OH}_{(a q)}^{-}}{\text {basa }} \rightarrow \frac{\mathrm{Na}_{(\text {aq })}^{+}+\mathrm{Cl}_{(a q)}^{-}}{\text {garam }}+\frac{\mathrm{H}_{2} \mathrm{O}}{\text { air }}
$$

Atau dapat juga melalui persamaan ionik total, yaitu:

$$
\mathrm{H}_{(a q)}^{+}+\mathrm{OH}_{(a q)}^{-} \rightarrow \mathrm{H}_{2} \mathrm{O}
$$

\section{Asam Basa Air}

Dari data di atas, Teori Arrhenius mengemukakan bahwa reaksi netralisasi melibatkan penggabungan hidrogen dan ion hidroksida yang akan membentuk air.

Keterbatasan Teori Arrhenius. Keberhasilan teori ini mengenai asam dan basa namun juga memiliki keterbatasan yang sangat penting. Salah satunya yaitu tentang basa lemah amonia, $\mathrm{NH}_{3}$. Menurut teori Arrhenius, senyawa dapat dikatakan basa jika mengandung $\mathrm{OH}^{-}$tetapi senyawa $\mathrm{NH}_{3}$ tidak mengandung $\mathrm{OH}^{-}$. Untuk menanggulangi keadaan ini, teori dari Arrhenius ini mengemukakan bahwa dalam larutan air $\mathrm{NH}_{3}$ membentuk senyawa amonium hidroksida $\left(\mathrm{NH}_{4} \mathrm{OH}\right)$, yang selanjutnya akan terurai sebagai basa lemah menjadi $\mathrm{NH}_{4}{ }^{+}$dan $\mathrm{OH}^{-}$. Reaksinya sebagai berikut :

$$
\mathrm{NH}_{3(a q)}+\mathrm{H}_{2} \mathrm{O} \rightarrow \mathrm{NH}_{4} \mathrm{OH}_{(a q)}
$$




$$
\mathrm{NH}_{4} \mathrm{OH}_{(a q)} \leftrightarrow \mathrm{NH}_{4}^{+}{ }_{(a q)}+\mathrm{OH}_{(a q)}^{-}
$$

Dari permasalahan di atas sebenarnya senyawa $\mathrm{NH}_{4} \mathrm{OH}$ tidak nyata. Tampaknya dari penjelasan Arrhenius mengenai asam dan basa, ia tidak mempertimbamngkan peran penting dari pelarut dalam penguraian zat terlarut.

\subsection{Menghitung pH Selama Titrasi}

Titrasi Asam Basa. Reaksi ini memiliki titik akhir titrasi yang perubahan warna nya cukup tajam dan mudah untuk diamati secara visual. Oleh karena itu, penambahan indikator sangat diperlukan dalam setiap proses titrasi. Indikator memiliki warna berbeda pada lingkungan $\mathrm{pH}$ yang berbeda, oleh sebab itu, indikator membantu perubahan warna pada saat titik akhir titrasi berlangsung. Selama proses titrasi berlangsung $\mathrm{pH}$ larutan sedikit demi sedikit berubah secara signifikan sampai mencapai titik akhir titrasi.

Kurva Titrasi Asam Basa. Kurva titrasi dibuat untuk mengetahui perubahan $\mathrm{pH}$ larutan terhadap volume penitrasi. Pada kurva titrasi inilah dapat dengan mudah mengamati perkembangan perubahan $\mathrm{pH}$ pada larutan sebelum tercapainya titik ekivalen dan adanya perubahan warna pada larutan saat penambahan sedikit demi sedikit volume penitrasi. Untuk titrasi asam lemah perubahan $\mathrm{pH}$ pada titik ekivalen kurang nyata dibandingkan dengan titrasi asam kuat. Perubahan $\mathrm{pH}$ pada larutan terkait dengan perubahan warna pada indikator dan penentuan titik akhir titrasi. Pemilihan indikator yang tepat akan menghasilkan tingkat ketajaman warna yang baik pula. Pemilihan indikator menjadi faktor penting dalam memperoleh data kuantitatif analit dengan tingkat validitas yang tinggi. 
pH selama titrasi. Selama proses titrasi penghitungan $\mathrm{pH}$ merupakan upaya yang penting untuk merealisasikan pemilihan indikator. $\mathrm{pH}$ yang sebelumnya telah diketahui di bandingkan dengan volume penitrasi yang akan digunakan untuk membentuk kurva titrasi. Urutan langkah ini yaitu:

$>$ Menghitung $\mathrm{pH}$ larutan awal (asam,basa atau garam)

> Menghitung pH larutan selama titrasi sampai sebelum titik ekivalen tercapai

$>$ Menghitung $\mathrm{pH}$ pada saat titik ekivalen

$>$ Menghitung $\mathrm{pH}$ setelah tercapai titik ekivalen

\subsection{Indikator Titrasi}

Indikator merupakan larutan yang ditambahkan pada titrasi asam maupun basa yang berguna untuk melihat adanya perubahan warna pada titran yang menunjukkan titik akhir titrasi telah tercapai. Pemilihan indikator untuk setiap larutan sangatlah penting untuk membantu keberhasilan titrasi yang telah dilakukan. Pemilihan indikator yang tidak sesuai akan menyebabkan terjadinya kesalahan dalam penentuan titik akhir titrasi seperti perubahan warna yang tidak sesuai dengan prosedur atau tidak adanya perubahan warna yang terjadi. Pemilihan indikator yang akan digunakan dalam titrasi asam basa harus memperlihatkan trayek $\mathrm{pH}$ indikator tersebut. Menurut Ostwald indikator asam basa adalah suatu asam atau basa organik lemah yang mempunyai warna berbeda dalam bentuk molekul dan ionnya pada keadaan kesetimbangan. Dalam kata lain indikator itu larutan yang membuat antara titran dan analit berubah menjadi pH yang seimbang. 
Misalnya terdapat indikator asam lemah yang berwarna merah(HIn) karena bentuk molekul dari HIn berwarna merah, sedangkan bentuk terionisasinya berwarna kuning.

$$
\begin{array}{cc}
\text { HIn } \leftrightarrow \mathbf{H}^{+}+ & \text {In- }^{-} \\
\text {Merah } & \text { Kuning }
\end{array}
$$

Perubahan warna merah dari HIn menjadi warna kuning $\left(\mathrm{In}^{-}\right)$terjadi pada kisaran $\mathrm{pH}$ tertentu. Ketelitian seseorang dalam melihat perubahan warna tersebut menjadi salah satu hal yang perlu diperhatikan. Sebelum terjadi perubahan warna tersebut, terjadi transisi antara warna merah(HIn) dan warna kuning $\left(\ln ^{-}\right)$ kemungkinan transisi warna yang terjadi yaitu warna orange. Umunya hanya satu warna yang akan terlihat, yaitu ketika perbandingan $\left[\mathrm{In}^{-}\right]$dan $[\mathrm{HIn}]$ adalah $10: 1$. Dengan demikian hanya warna dengan konsentrasi yang paling tinggi yang akan terlihat. Sebagai contoh jika hanya warna kuning yang terlihat maka konsentrasi $\left[\mathrm{In}^{-}\right] /[\mathrm{HIn}]=10 / 1$, sehingga jika dimasukkan ke persamaan Henderson-Hasselbalch diperoleh:

$$
p H=p K a+\log 10 / 1=p K a+1
$$

Dan jika hanya warna merah yang terlihat maka konsentrasi $\left.\left[\mathrm{In}^{-}\right] / \mathrm{HIn}\right]=1 / 10$ sehingga diperoleh:

$$
\mathrm{pH}=\mathrm{pKa}+\log 1 / 10=\mathrm{pKa}-1
$$


Jadi terjadinya perubahan $\mathrm{pH}$ pada indikator dari satu warna ke warna yang lain terjadi pada $\mathrm{pH}$ berkisar antara pKa-1 sampai dengan pKa+1. Pada titik tengah atau saat terjadi transisi warna, maka konsentrasi [ $\left.\mathrm{In}^{-}\right]$akan sama dengan [HIn]. Oleh sebab itu $\mathrm{pH}=$ pKa. Maka dari itu jarak antara perubahan warna indikator satu ke warna lain merupakan trayek perubahan warna indikator yang nilainya mencakup dua satuan $\mathrm{pH}$. Contoh indikator asambasa yang biasa digunakan yaitu fenolftalein dan metil orange.

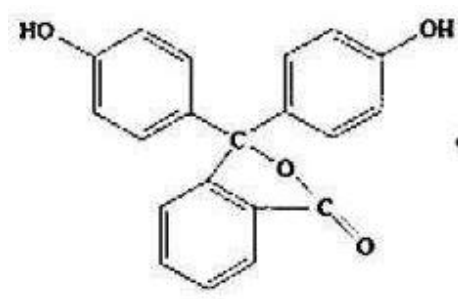

takberwarna

PP

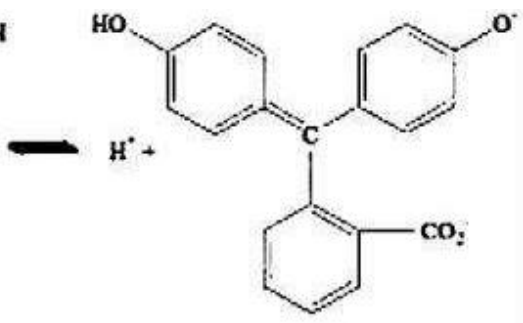

merah

dalam bentuk asam (HIn) dakam bentuk basa (In-)

Gambar 3.1 Struktur Molekul Indikator Fenolftalein 

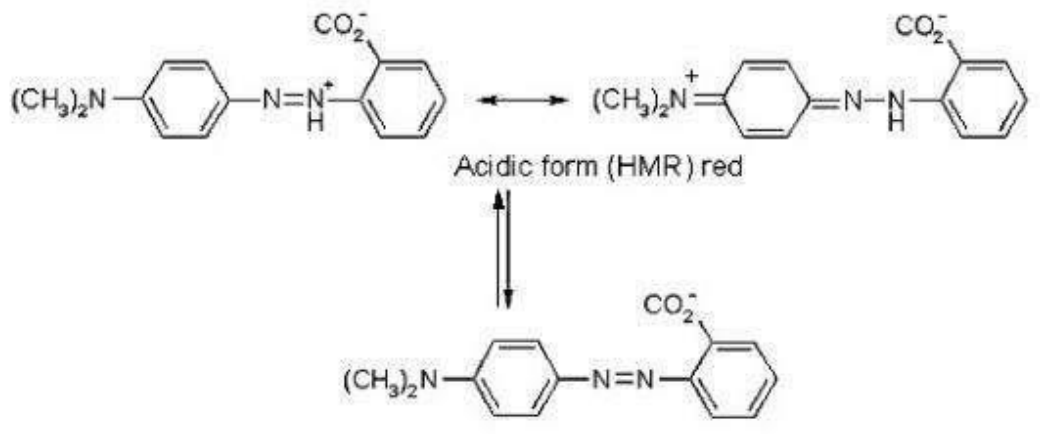

Basic form (MR-) yellow

Gambar 3.2 Struktur Molekul Indikator Metil Oranye

\subsection{Titrasi Asam Kuat dengan Basa Kuat}

Asam kuat dan basa kuat di dalam air terjadi peruraian sempurna, sehingga $\mathrm{pH}$ larutan dapat dihitung langsung dari jumlah stoikiometri asam basa yang bereaksi. Pada keadaan tersebut, reaksi antara asam kuat dan basa kuat dapat ditentukan nilai $\mathrm{pH}$ nya. $\mathrm{pH}$ air murni berkisar pada suhu $25^{\circ} \mathrm{C}$. Indikator asam basa yang sering digunakan untuk percobaan yaitu indikator Methyl Orange (MM), Phenolphtalein (PP) dan Bromtimol Biru (BB) karena pada titik akhir titrasinya perubahan warna dapat dengan mudah untuk di amati dengan mata secara langsung.

Contoh reaksi antara asam kuat dan basa kuat adalah titrasi asam klorida dengan natrium hidroksida, yaitu:

$$
\mathrm{HCl}_{(a q)}+\mathrm{NaOH}_{(a q)} \rightarrow \mathrm{NaCl}_{(a q)}+\mathrm{H}_{2} \mathrm{O}_{(\mathrm{l})}
$$


Larutan $\mathrm{HCl}$ terionisasi sempurna di dalam air menjadi ion $\mathrm{H}^{+}$dan $\mathrm{Cl}^{-}$. larutan $\mathrm{NaOH}$ juga terionisasi sempurna di dalam air menjadi $\mathrm{Na}^{+}$dan $\mathrm{OH}^{-}$. Reaksi yang terjadi adalah:



$\mathrm{H}_{(a q)}^{+}+\mathrm{Cl}_{(a q)}^{-}+\mathrm{Na}_{(a q)}^{+}+\mathrm{OH}_{(a q)}^{-} \rightarrow \mathrm{Na}_{(a q)}^{+}+\mathrm{Cl}_{(a q)}^{-}+\mathrm{H}_{2} \mathrm{O}_{(\mathrm{l})}$

Jadi reaksi ion antara asam kuat dengan basa kuat yaitu:

$$
H_{(a q)}^{+}+\mathrm{OH}_{(a q)}^{-} \leftrightarrow \mathrm{H}_{2} \mathrm{O}_{(l)}
$$

(hidrogen)

(hidroksida)

(air)

Dari reaksi tersebut dapat diartikan menjadi ion hidrogen $\left(\mathrm{H}^{+}\right)$ bereaksi dengan ion hidroksida $\left(\mathrm{OH}^{-}\right)$membentuk air $\left(\mathrm{H}_{2} \mathrm{O}\right)$ jadi dapat diartikan bahwa larutan tersebut dalam kondisi netral dengan $\mathrm{Ph} 7$ pada saat titik ekivalen terjadi.

Kurva titrasi $50 \mathrm{~mL} \mathrm{HCl}$ 0,1 M dengan $\mathrm{NaOH}$ 0,20 M sebagai berikut:

Gambar 3.3 Kurva titrasi $\mathrm{HCl}$ dengan $\mathrm{NaOH}$ 
Sebanyak $50 \mathrm{~mL} \mathrm{HCl} \mathrm{0,1} \mathrm{M} \mathrm{yang} \mathrm{terdapat} \mathrm{pada} \mathrm{erlenmeyer}$ (analit) dititrasi dengan larutan $\mathrm{NaOH} \mathrm{0,2} \mathrm{M} \mathrm{yang} \mathrm{bertindak} \mathrm{sebagai}$ titran. Sebelum dilakukannya titrasi maka analit hanya terdapat 0,1 $\mathrm{M} \mathrm{HCl}$ yang memiliki $\mathrm{pH} 1$. Saat titrasi berlangsung, $\mathrm{pH}$ akan meningkat sedikit demi sedikit akibat jumlah ion $\mathrm{H}^{+}$yang semakin menurun(berkurang). Penambahan larutan $\mathrm{NaOH} 10 \mathrm{~mL}$ dapat menyebabkan dalam larutan konsentrasi $\mathrm{H}^{+}$berkisar $0,05 \mathrm{M}$, sehingga $\mathrm{pH}$ berubah yang awalnya 1 menjadi 1,3. Peningkatan $\mathrm{pH}$ terus naik sampai pada titik ekiuvalen, pada saat titik ekuivalen inilah larutan memiliki $\mathrm{pH}$ netral yaitu 7. Penambahan $\mathrm{NaOH}$ selanjutnya akan meningkatkan $\mathrm{pH}$ dari konsentrasi $10^{-7} \mathrm{M}$ untuk ion $\mathrm{OH}^{-}$menjadi $0,0125 \mathrm{M}$ hanya dengan penambahan $5 \mathrm{~mL} \mathrm{NaOH}$ saja.

\subsection{Titrasi Asam Lemah dengan Basa Kuat}

Contoh dari asam lemah yaitu asam asetat, $\mathrm{CH}_{3} \mathrm{COOH}$ yang akan dititrasi dengan basa kuat yaitu $\mathrm{NaOH}$.

Reaksi yang terjadi :

$$
\begin{aligned}
& \mathrm{CH}_{3} \mathrm{COOH}_{(a q)}+\mathrm{NaOH}_{(a q)} \rightarrow \mathrm{CH}_{3} \mathrm{COONa}_{(a q)}+\mathrm{H}_{2} \mathrm{O}_{(l)} \\
& \mathrm{CH}_{3} \mathrm{COOH}_{(a q)} \leftrightarrow \mathrm{H}_{(a q)}^{+}+\mathrm{CH}_{3} \mathrm{COO}_{(a q)}^{-} \quad \text { pKa }=4,76
\end{aligned}
$$

Dilakukan titrasi antara $50 \mathrm{~mL}$ larutan $\mathrm{CH}_{3} \mathrm{COOH} 0,1 \mathrm{M}$ dengan larutan $\mathrm{NaOH}$ 0,100 M. Sebelum dilakukannya titrasi, di dalam erlenmeyer hanya terdapat asam asetat. Asam asetat termasuk 
dalam asam lemah maka tidak dapat terionisasi dengan sempurna. Karena konsentrasi ion $\mathrm{H}^{+}$tidak sama dengan konsentrasi asam lemah, maka harus dilakukan perhitungan dari besarnya tetapan kesetimbangan asam (Ka) dari asam asetat. Hasil perhitungan menunjukkan $50 \mathrm{~mL} \mathrm{CH}{ }_{3} \mathrm{COOH}$ 0,1 M memiliki pH berkisar 2,88.

Gambar 3.4 Kurva Titrasi

Saat titrasi berlangsung penambahan larutan $\mathrm{NaOH}$ sedikit demi sedikit ke dalam larutan $\mathrm{CH}_{3} \mathrm{COOH}$ akan membentuk $\mathrm{CH}_{3} \mathrm{COONa}$ sebagai hasil reaksi. Dalam erlenmeyer terdapat $\mathrm{CH}_{3} \mathrm{COOH}$ yang belum bereaksi dengan $\mathrm{CH}_{3} \mathrm{COONa}$, sehingga akan terbentuk sistem buffer. Dalam kondisi ini pH sedikit demi sedikit akan mengalami kenaikan sebagai fungsi dari perubahan perbandingan $\left[\mathrm{CH}_{3} \mathrm{COO}^{-}\right]$dengan $\left[\mathrm{CH}_{3} \mathrm{COOH}\right]$. Penambahan $10 \mathrm{~mL}$ larutan $\mathrm{NaOH} 0,100 \mathrm{M}$ pada analit $\mathrm{CH}_{3} \mathrm{COOH}$ dapat menaikkan $\mathrm{pH}$ yang awalnya 2,88 menjadi 4,16.

Pada titik tengah titrasi, setengah dari jumlah total mol $\mathrm{NaOH}$ maupun $\mathrm{CH}_{3} \mathrm{COOH}$ mengalami reaksi yang menyebabkan konsentrasi $\mathrm{CH}_{3} \mathrm{COO}^{-}$akan seimbang dengan konsentrasi $\mathrm{CH}_{3} \mathrm{COOH}$ dengan $\mathrm{pH}$ sesuai dengan pKa yaitu 4,76. Pada saat titik ekuivalen berlangsung, $\mathrm{CH}_{3} \mathrm{COOH}$ telah habis bereaksi sehingga didalam erlenmeyer hanya terdapat $\mathrm{CH}_{3} \mathrm{COONa}$ saja. Larutan $\mathrm{CH}_{3} \mathrm{COONa}$ adalah garam yang terbentuk dari reaksi antara basa kuat dengan asam lemah, sehingga didalam air dapat terhidrolisis sebagian.

Sesuai dengan reaksi : 


\section{$\mathrm{CH}_{3} \mathrm{COONa}_{(a q)} \rightarrow \mathrm{Na}^{+}(\mathrm{aq})+\mathrm{CH}_{3} \mathrm{COO}_{(a q)}^{-}$ \\ $\mathrm{CH}_{3} \mathrm{COO}_{(a q)}^{-}+\mathrm{H}_{2} \mathrm{O}_{(\mathrm{ll})} \leftrightarrow \mathrm{CH}_{3} \mathrm{COOH}_{(a q)}+\mathrm{OH}_{(a q)}^{-}$}

Adanya ion $\mathrm{OH}^{-}$sebagai akibat terjadinya hidrolisis parsial dari $\mathrm{CH}_{3} \mathrm{COON}$ yang menyebabkan $\mathrm{pH}$ larutanm mengalami kenaikan dan bersifat basa. Dengan demikian perhitungan $\mathrm{pH}$ larutan ditentukan oleh konsentrasi $\mathrm{CH}_{3} \mathrm{COONa}$, tetapan Ka dan tetapan kesetimbangan air. Jadi pada saat titik ekuivalen berlangsung $\mathrm{pH}$ larutan berkisar 8,73. Nilai $\mathrm{pH}$ tersebut berada pada trayek $\mathrm{pH}$ indikator fenolftalein. Maka indikator yang tepat dan sesuai pada titrasi ini yaitu indikator fenolftalein(PP).

Jika menggunakan indikator lain seperti Methyl Orange, maka saat penambahan larutan $\mathrm{NaOH}$ setelah tercapainya titik ekivalen $\mathrm{pH}$ larutan akan ditentukan oleh konsentrasi dari ion $\mathrm{OH}^{-}$ dari $\mathrm{NaOH}$ karena pada saat setelah titik ekivalen tercapai ion $\mathrm{OH}^{-}$ hasil dari hidrolisis $\mathrm{CH}_{3} \mathrm{COONa}$ dapat diabaikan, akibatnya ion $\mathrm{OH}^{-}$ dari $\mathrm{NaOH}$ lebih dominan dari pada ion $\mathrm{OH}^{-}$dari hasil hidrolisis $\mathrm{CH}_{3} \mathrm{COONa}$. Oleh sebab itu, $\mathrm{pH}$ larutan akan semakin meningkat dan semakin bersifat basa yang mengakibatkan saat titik akhir titrasi berlangsung akan sukar untuk diamati.

\subsection{Titrasi Basa Lemah dengan Asam Kuat}


Sebagai contoh larutan amonium hidroksida $\left(\mathrm{NH}_{4} \mathrm{OH}\right) 0,1 \mathrm{M}$ dengan volume $100 \mathrm{~mL}$ dititrasi dengan larutan $\mathrm{HCl}$ 0,100 M. Reaksi yang terjadi :

$$
\begin{gathered}
\mathrm{NH}_{4} \mathrm{OH}_{(a q)}+\mathrm{HCl}_{(a q)} \rightarrow \mathrm{NH}_{4} \mathrm{Cl}_{(a q)}+\mathrm{H}_{2} \mathrm{O}_{(l)} \\
\mathrm{NH}_{4} \mathrm{OH}_{(a q)} \leftrightarrow \mathrm{NH}_{4}^{+}(a q) \\
+\mathrm{OH}_{(a q)}^{-} \quad \mathrm{Kb}=10^{-5}
\end{gathered}
$$

Gambar 3. 5 Kurva Titrasi $100 \mathrm{~mL} \mathrm{NH}_{4} \mathrm{OH}$ 0,1 M dengan $\mathrm{HCl} 0,1 \mathrm{M}$

Saat awal dilakukannya titrasi, larutan yang terdapat di dalam erlenmeyer hanya $\mathrm{NH}_{4} \mathrm{OH}$. Larutan $\mathrm{NH}_{4} \mathrm{OH}$ memiliki pKb $=5$ yang termasuk basa lemah, sehingga larutan tersebut saat didalam air tidak mengalami ionisasi sempurna atau hanya sebagian. Oleh sebab itulah $\mathrm{pH}$ awal titrasi yaitu 11 .

Pada titik tengah titrasi berlangsung, setengah dari jumlah mol $\mathrm{NH}_{4} \mathrm{OH}$ telah habis bereaksi, maka konsentrasi dari $\left[\mathrm{NH}_{4} \mathrm{Cl}\right]$ sama dengan konsentrasi dari $\left[\mathrm{NH}_{4} \mathrm{OH}\right]$. Oleh sebab itu, nilai $\mathrm{pH}=$ pKw-pKb yaitu sekitar 9. Saat berada pada titik ekuivalen, maka didalam erlenmeyer hanya terdapat amonium klorida. Amonium klorida merupakan garam yang terbentuk akibat dari reaksi antara asam kuat dengan basa lemah, sehingga larutan garam tersebut akan terhidrolisis parsial.

Reaksi yang terjadi yaitu :

$$
\mathrm{NH}_{4} \mathrm{Cl}_{(a q)} \rightarrow \mathrm{NH}_{4}^{+}{ }_{(a q)}+\mathrm{Cl}_{(a q)}^{-}
$$




$$
\mathrm{NH}_{4}{ }^{+}{ }_{(a q)}+\mathrm{H}_{2} \mathrm{O}_{(l)} \leftrightarrow \mathrm{NH}_{4} \mathrm{OH}_{(a q)}+\mathrm{H}_{(a q)}
$$

Adanya ion $\mathrm{H}^{+}$pada larutan mengakibatkan larutan bersifat asam akibat hasil dari hidrolisis garam parsial tersebut. Nilai $\mathrm{pH}$ titrasi antara $\mathrm{NH}_{4} \mathrm{OH}$ dengan $\mathrm{HCl}$ saat titik ekuivalen berlangsung berkisar 5,2 . Oleh sebab itu, indikator yang digunakan pada titrasi ini yaitu indikator Metil Oranye(MO) yang memiliki perubahan warna pada trayek pH berkisar 4,4-6.2.

Jika menggunakan indikator lain seperti fenolftalein (PP), maka pada saat setelah titik ekivalen berlangsung penambahan larutan $\mathrm{HCl}$ akan menyebabkan larutan bersifat asam. Dalam hal ini, ion $\mathrm{H}^{+}$hasil hidrolisis dari garam amonium klorida dapat diabaikan yang berakibat ion $\mathrm{H}^{+}$hasil ionisasi dari $\mathrm{HCl}$ lebih dominan dan menyebabkan $\mathrm{pH}$ larutan setelah titik ekivalen berlangsung mengalami penurunan dan semakin menurun yang menyebabkan $\mathrm{pH}$ larutan bersifat asam yang dapat berakibat dalam penentuan titik akhir titrasi akan sukar untuk diamati.

\subsection{Titrasi Asam Lemah dengan Basa Lemah}

Pada titrasi asam lemah dengan basa lemah tidak mengalami kenaikan yang tajam pada kurva titrasinya, sehingga sulit memilih indikator yang cocok untuk titrasi ini, yang digunakan untuk menentukan titik akhir titrasi. Oleh sebab itu, titrasi antara asam lemah dengan basa lemah jarang sekali digunakan dalam metode analisis kuantitatif.

Sebagai contoh yaitu titrasi antara larutan $\mathrm{CH}_{3} \mathrm{COOH}$ sebagai asam lemah dengan larutan $\mathrm{NH}_{4} \mathrm{OH}$ sebagai basa lemah, sehingga akan membentuk garam yang berasal dari reaksi asam 
lemah dengan basa lemah. Jika Ka>Kb kelarutannya akan bersifat asam, jika Kb>Ka maka kelarutannya akan bersifat basa.

Reaksinya yaitu :

$$
\mathrm{CH}_{3} \mathrm{COOH}+\mathrm{NH}_{4} \mathrm{OH} \rightarrow \mathrm{CH}_{3} \mathrm{COONH}_{4}+\mathrm{H}_{2} \mathrm{O}
$$

\subsection{Titrasi Asam dan Basa Poliprotik}

Asam dan Basa Poliprotik. Asam poliprotik merupakan asam yang memiliki kemampuan untuk melepaskan ion $\mathrm{H}^{+}$yang lebih dari satu di dalam larutan. Suatu asam poliprotik $H_{n} \mathrm{~A}$ dalam bentuk yang disederhanakanm akan mengalami reaksi dissosiasi :
$H_{n} A$
$\leftrightarrow \quad \mathrm{H}^{+}+H_{(n-1)} A^{-}$
dengan $\mathrm{Ka}_{1}$
$H_{(n-1)} A^{-}$
$\leftrightarrow$
$\mathrm{H}^{+}+H_{(n-2)} A^{2-}$
dengan $K a_{2}$
$H_{(n-2)} A^{2-}$
$\leftrightarrow$
$\mathrm{H}^{+}+H_{(n-3)} A^{3-}$
dengan $\mathrm{Ka}_{3}$

Seterusnya....
$H A^{(n+1)^{-}}$
$\leftrightarrow \quad \mathrm{H}^{+}+A^{n^{-}}$
dengan $K a_{n}$

$\left(K a_{1}>K a_{2}>K a_{3}>\ldots . K a_{n}\right)$. Suatu basa poliprotik memiliki analogi dengan konsep tersebut

Jika perbandingan angka dari $K a_{1}$ dengan yang lain secara berurutan memiliki faktor sebesar $10^{4}$ sampai dengan $10^{5}$, maka asam poliprotik dianggap sebagai campuran dari beberapa asam monoprotik yang memiliki faktor Ka sendiri. Titrasi dari asam 
poliprotik yang demikian akan dapat ditemukan adanya titik ekivalen yang lebih dari satu.

Contoh dari asam poliprotik yaitu titrasi antara asam fosfat dengan $\mathrm{H}_{3} \mathrm{PO}_{4}$. Asam fosfat akan mengalami reaksi dissosiasi sebagai berikut :

$$
\begin{aligned}
& \mathrm{H}_{3} \mathrm{PO}_{4} \leftrightarrow \mathrm{H}^{+}+\mathrm{H}_{2} \mathrm{PO}_{4}^{-} \quad K a_{1}=\frac{\left[H^{+}\right]\left[\mathrm{H}_{2} \mathrm{PO}^{4-}\right]}{\left[\mathrm{H}^{3} \mathrm{PO}^{4}\right]} \\
& K a_{1}=7,11 \times 10^{-3} \\
& \mathrm{H}_{2} \mathrm{PO}_{4}{ }^{2-} \leftrightarrow \mathrm{H}^{+}+\mathrm{HPO}_{4}{ }^{2-} \quad K a_{2}=\frac{\left[\mathrm{H}^{+}\right]\left[\mathrm{HPO}^{42-}\right]}{\left[\mathrm{H}^{2} \mathrm{PO}^{4-}\right]} \\
& K a_{2}=6,32 \times 10^{-8} \\
& \mathrm{HPO}_{4}{ }^{2-} \leftrightarrow \mathrm{H}^{+}+\mathrm{PO}_{4}{ }^{3-} \quad \mathrm{Ka}_{3}=\frac{\left[\mathrm{H}^{+}\right]\left[\mathrm{PO}_{4}^{3-}\right]}{\left[\mathrm{HPO}_{4}{ }^{2-}\right]} \\
& K a_{3}=4,5 \times 10^{-13}
\end{aligned}
$$

Jika dilakukan titrasi antara larutan asam fosfat dengan larutan basa $\mathrm{NaOH}$, maka :

- Titik ekivalen I tercapai saat terbentuknya $\mathrm{NaH}_{2} \mathrm{PO}_{4}$

- Titik ekivalen II tercapai saat terbentuknya $\mathrm{Na}_{2} \mathrm{HPO}_{4}$

- Titik ekivalen III tercapai saat terbentuknya $\mathrm{Na}_{-} \mathrm{PO}_{4}-$

\subsection{Titrasi Pemindahan}

Larutan yang termasuk dalam garam dapat dititrasi dengan suatu larutan yang bersifat asam yang akan menyebabkan tergantinya ion-ion yang terdapat dalam garam oleh ion-ion dari 
suatu zat penitrasi tersebut. Jika suatu larutan garam monobasis $\mathrm{KA}$ (terhidrolisis) dititrasi menggunakan asam kuat $\mathrm{HCl}$, maka ion $\mathrm{A}^{+}$ dari larutan garam KA akan digantikan oleh ion $\mathrm{Cl}^{-}$dari $\mathrm{HCl}$ yang akan menjadi $\mathrm{KCl}$ dan proses titrasi inilah yang disebut dengan titrasi pemindahan. $\mathrm{pH}$ selama titrasi yaitu :

$\mathrm{pH}$ larutan awal

$$
\begin{aligned}
& =\mathrm{pH} \text { garam terhidrolisis } \\
& =1 / 2(\mathrm{pKw}+\mathrm{pKa}+\log [\text { garam }])
\end{aligned}
$$

* pH sebelum titik ekivalen

$\mathrm{pH}$ pada proses ini merupakan $\mathrm{pH}$ larutan buffer yang terjadi karena adanya campuran dari asam HA yang terbentuk dan sisa garam dari KA, maka :

$$
\mathrm{pH}=\mathrm{pKa}+\log \frac{[\text { garam }]}{[\text { asam }]}
$$

dengan adanya sisa dari garam KA dan asam HA yang terbentuk.

$\mathrm{pH} 1 / 2$ netral $=\mathrm{pKa}$

* $\mathrm{pH}$ pada saat mencapai titik ekivalen $=-\log \sqrt{\mathrm{Ka} x[\mathrm{HA}]}$

* $\mathrm{pH}$ setelah titik ekivalen : $\mathrm{pH}$ penitrasi

Titrasi Pemindahan dengan Penitrasi Berbeda Valensi. Jika dilakukannya titrasi antara larutan garam dari $\mathrm{Na}_{2} \mathrm{CO}_{3}$ dengan larutan asam kuat $\mathrm{HCl}$, maka perhitungan $\mathrm{pH}$ selama titrasi yaitu :

$\mathrm{pH}$ larutan awal $=\mathrm{pH}$ hidrolisis

$$
\mathrm{pH}=1 / 2(p K w+p K a+\log [\text { garam }])
$$

* $\mathrm{pH}$ sebelum titik ekivalen tercapai $=\mathrm{pH}$ buffer asam (sisa dari larutan $\mathrm{Na}_{2} \mathrm{CO}_{3}$ dan $\mathrm{NHCO}_{3}$ ) terbentuk

* $\mathrm{pH}$ pada saat titik ekivalen I berlangsung $(=1 / 2$ netral $)=$ $1 / 2\left(\mathrm{pKa}_{1}+\mathrm{pKa}_{2}\right)$ 
* pH setelah titik ekivalen $\mathrm{I}=\mathrm{pH}$ buffer asam (sisa dari larutan $\mathrm{Na}_{2} \mathrm{CO}_{3}$ dan $\mathrm{NHCO}_{3}$ ) terbentuk

* pH pada saat titik ekivalen II $=\mathrm{pH}$ asam lemah yang terbentuk yaitu $\mathrm{H}_{2} \mathrm{CO}_{3}$

* pH setelah titik ekivalen II $=\mathrm{pH}$ asam kuat (

\subsection{Rangkuman}

$>$ Asam berasal dari bahasa latin yaitu acidus (asam), yang berkaitan dengan kata acer (tajam) dan acetum (cuka).

$>$ alkali (basa) berasal dari bahasa Arab yaitu al-qali yang berarti abu dari suatu tanaman yang ada kaitannya dengan daerah rawa garam dan padang pasir.

> Antoine Lavoisier (1777) mengemukakan bahwa semua dari asam mengandung $\mathrm{O}_{2}$ (oksigen).

$>$ Humphry Davy (1810) mengemukakan bahwa unsur dalam asam bukan oksigen tetapi hidrogen, yang ditunjukkan oleh asam hidrokhlorik yang mengandung hanya atom $\mathrm{H}$ dan $\mathrm{Cl}$ tanpa ada $\mathrm{O}$.

> Svante Arrhenius (1884). Berdasarkan teori tentang penguraian elektrolisis, bahwa terdapat dua macam larutan elektrolit (larutan dalam air).

$\mathrm{pH}$ merupakan derajat keasaman suatu bahan $(\mathrm{pH}$ asam $<7$, netral $=7$, basa $>7$ )

$>$ Indikator merupakan larutan yang ditambahkan pada titrasi asam maupun basa yang berguna untuk melihat adanya perubahan warna pada titran yang menunjukkan titik akhir titrasi telah tercapai. 


\subsection{Contoh dan Latihan Soal}

\section{Contoh soal 1.}

Hitung nilai $\mathrm{pH}$ larutan asam sulfat $0,05 \mathrm{M}$ !

Penyelesaian:

Asam sulfat memiliki rumus kimia $\mathrm{H}_{2} \mathrm{SO}_{4}$ dan merupakan asam kuat. Asam sulfat diasumsikan dapat mengion secara sempurna:

$\mathrm{H}_{2} \mathrm{SO}_{4} \rightarrow 2 \mathrm{H}^{+}+\mathrm{SO}_{4}{ }^{2-}$

$0,05 \mathrm{M} \quad 0,1 \mathrm{M} \quad 0,05 \mathrm{M}$

$\left[\mathrm{H}^{+}\right]=0,1 \mathrm{M}=10^{-1} \mathrm{M}$

$\mathrm{pH}=-\log \left[\mathrm{H}^{+}\right]=-\log \left(10^{-1}\right)=1$

\section{Contoh soal 2.}

Hitung $\mathrm{pH}$ larutan $\mathrm{NH}_{3}$ 0,2 $\mathrm{M}$ (nilai $\mathrm{Kb} \mathrm{MH}_{3}=2 \times 10^{-5}$ )!

Penyelesaian:

Larutan $\mathrm{NH}_{3}$ merupakan larutan yang bersifat basa lemah.

$\left[\mathrm{OH}^{-}\right]=\sqrt{\mathrm{Kb} \times \mathrm{Mb}}=\sqrt{\left(2 \times 10^{-5}\right) \times\left(2 \times 10^{-1}\right)}=$ $\sqrt{4 \times 10^{-6}}=2 \times 10^{-3}$

$\mathrm{pOH}=-\log \left[\mathrm{OH}^{-}\right]=-\log 2 \times 10^{-3}=3-\log 2$

$\mathrm{pH}=14-\mathrm{pOH}=14-(3-\log 2)=11+\log 2$

\section{Latihan Soal}

Kerjakanlah soal di bawah ini!

1. Sebanyak $50 \mathrm{ml} \mathrm{HCl} \mathrm{0,1} \mathrm{M} \mathrm{dititrasi} \mathrm{dengan} \mathrm{NaOH}$ $0,1 \mathrm{M}$ dengan reaksi:

$\mathrm{HCl}_{(\mathrm{aq})}+\mathrm{NaOH}_{(\mathrm{aq})} \rightarrow \mathrm{NaCl}_{(\mathrm{aq})}+\mathrm{H}_{2} \mathrm{O}_{(\mathrm{l})}$ atau

$\mathrm{H}^{+}\left(\right.$aq) $+\mathrm{OH}_{(\mathrm{aq})}^{-} \rightarrow \mathrm{H}_{2} \mathrm{O}_{(\mathrm{l})}$

Hitunglah $\mathrm{pH}$ :

a. Sebelum penambahan $\mathrm{NaOH}$

b. Setelah penambahan $\mathrm{NaOH} 10,50,55,60,70$, 80 , dan $100 \mathrm{~mL}$

c. Buatlah kurva titrasinya 


\section{BAB 4}

\section{TITRASI ARGENTOMETRI}

\section{Sub-Capaian Pembelajaran Mata Kuliah}

1. Mahasiswa mampu memahami analisis argentometri.

2. Mahasiswa mampu menjelaskan reaksi pengendapan dan definisi titrasi argentometri dengan memberikan contoh dan menuliskan persamaan reaksinya.

3. Mahasiswa mampu melakukan titrasi argentometri dan menentukan titik akhir dari kurva titrasi.

4. Mahasiswa mampu membedakan reaksi pengendapan dengan reaksi pembentukan kompleks.

\section{a. Reaksi Pengendapan Titrasi Argentometri}

Prinsip reaksi pengendapan sering digunakan untuk metode gravimetri. Titrasi pengendapan yang melibatkan pereaksi pengendap dengan perak nitrat dikenal dengan sebutan titrasi argentometri.

Di dalam titrasi argentometri dikenal terdapat 3 metode yaitu metode Mohr, metode Volhard, dan metode Fajans.

\section{a. Metode Mohr}

Dalam metode Mohr ini indikator yang digunakan yaitu kalium kromat $\left(\mathrm{K}_{2} \mathrm{CrO}_{4}\right)$. Pada metode ini larutan standar yang digunakan yaitu perak nitrat $\left(\mathrm{AgNO}_{3}\right)$. Ion klorida merupakan larutan yang bertindak sebagai analit yang dapat ditentukan pada metode ini. Selama proses titrasi berlangsung akan 
terbentuk endapan putih akibat adanya perak klorida. Indikator yang digunakan pada metode ini yaitu larutan kalium kromat encer(sekitar 2\%).

Maka reaksi yang terjadi yaitu :

$\mathrm{Ag}_{(a q)}^{+}+\mathrm{Cl}_{(a q)}^{-} \rightarrow \mathrm{AgCl}_{(a q) p u t i h} \mathrm{Ksp} \mathrm{AgCl}=1,8 \times 10^{-10}$
$\mathrm{~K}_{2} \mathrm{CrO}_{4(a q)}+2 \mathrm{AgNO}_{3(a q)} \rightarrow 2 \mathrm{KNO}_{3(a q)}+\mathrm{Ag}_{2} \mathrm{CrO}_{4(s)}$

$\mathrm{Ksp} \mathrm{Ag}_{2} \mathrm{CrO}_{4}=1,7 \times 10^{-12}$

Berdasarkan data Ksp di atas, maka dapat dihitung kelarutan dari $\mathrm{AgCl}$ dan $\mathrm{Ag}_{2} \mathrm{CrO}_{4}$ dengan cara sebagai berikut :

- $\mathrm{AgCl}_{(s)} \leftrightarrow \mathrm{Ag}_{(a q)}^{-}+\mathrm{Cl}_{(a q)}^{-}$

Misal kelarutan $\mathrm{AgCl}=\mathrm{s}$ mol/L, maka: $\left[\mathrm{Ag}^{+}\right]=\left[\mathrm{Cl}^{-}\right]$

$=\mathrm{s} \mathrm{mol} / \mathrm{L}$, sehingga:

$\mathrm{Ksp}=\left[\mathrm{Ag}^{+}\right]\left[\mathrm{Cl}^{-}\right]$

$1,8 \times 10^{-10}=(\mathrm{s})(\mathrm{s})$

$$
\mathrm{s}=1,3 \times 10^{-5} \mathrm{~mol} / \mathrm{L}
$$

- $\mathrm{Ag}_{2} \mathrm{CrO}_{4(s)} \leftrightarrow 2 \mathrm{Ag}_{(a q)}^{+}+\mathrm{CrO}_{4}{ }^{2-}(a q)$

Misal kelarutan $\mathrm{Ag}_{2} \mathrm{CrO}_{4}=\mathrm{s} \mathrm{mol} / \mathrm{L}$, maka: $\left[\mathrm{Ag}^{+}\right]=2 \mathrm{~s}$ dan $\left[\mathrm{CrO}_{4}{ }^{2^{-}}\right]=\mathrm{s} \mathrm{mpl} / \mathrm{L}$, sehingga :

$\mathrm{Ksp}=\left[\mathrm{Ag}^{+}\right]^{2}\left[\mathrm{CrO}_{4}{ }^{2-}\right]$

$1,7 \times 10^{-12}=(2 \mathrm{~s})^{2}(\mathrm{~s})$

$$
\mathrm{s}^{3}=\left(7,5 \times 10^{-12}\right) / 4
$$$$
\mathrm{s}=7,5 \times 10^{-5} \mathrm{~mol} / \mathrm{L}
$$ 
Jadi berdasarkan perhitungan di atas $\mathrm{Ksp} \mathrm{AgCl}$ lebih kecil dibandingkan dengan $\mathrm{Ksp} \mathrm{Ag}_{2} \mathrm{CrO}_{4}$, maka dapat dipastikan bahwa pengendapan terlebih dahulu terjadi pada $\mathrm{AgCl}$ sebab memiliki Ksp (kelarutan) yang lebih rendah. Setelah semua ion klorida membentuk endapan, kelebihan ion $\mathrm{Ag}^{+}$akan bereaksi dengan indikator metode Mohr ini(kalium kromat) yang akan membentuk endapan dari $\mathrm{Ag}_{2} \mathrm{CrO}_{4}$ yang memiliki warna coklat kemerahan.

Konsentrasi dari ion perak pada saat titik ekivalen berlangsung ditentukan dengan harga $\mathrm{Ksp} \mathrm{AgCl}$ yaitu:

$$
\left[\mathrm{Ag}^{+}\right]=\sqrt{K s p}=\sqrt{1,8 \times 10^{-10}}=1,3 \times 10^{-5} \mathrm{M}
$$

dengan demikian konsentrasi dari ion kromat yang diperlukan untuk memperoleh endapan perak kromat yaitu :

$$
\left[\mathrm{CrO}_{4}{ }^{2-}\right]=\frac{K_{s p}}{\left[\mathrm{Ag}^{+}\right]^{2}}=\frac{1,7 \times 10^{-12}}{\left(1,3 \times 10^{-5}\right)^{2}}=0,01 \mathrm{M}
$$

Pada dasarnya agar terbentuk endapan perak kromat perlu penambahan konsentrasi ion kromat sebesar 0,01 $\mathrm{M}$. Tetapi jika ditambahkan sedemikian akan menyebabkan terbentuknya warna kuning yang sangat intensif pada analit. Hal ini menyebabkan warna endapan dari perak kromat akan sukar diamati karna adanya warna kuning tersebut. Oleh karena itu, penambahan konsentrasi ion kromat lebih kecil dari 0,01 $\mathrm{M}$ agar warna endapan dari perak kromat akan dapat dengan mudah terlihat. Biasanya konsentrasi ion kromat yang digunakan yaitu 0,005 $\mathrm{M}$ sampai dengan 0,01 $\mathrm{M}$.

Pada titrasi argentometri metode Mohr ini harus dilakukan pada $\mathrm{pH}$ kisaran 6,5-10. Hal ini dikarenakan ion 
kromat merupakan basa konjugasi dari asam kromat. Jika titrasi dilakukan pada $\mathrm{pH}<6,5$, maka ion kromat akan terprotonasi dalam bentuk $\mathrm{HCrO}_{4}$. Ion tersebut selanjutnya berubah menjadi ion kromat. Ion kromat inilah yang akan mendominasi didalam larutan. Oleh sebab itu, keasaman larutan pada titrasi argentometri metode Mohr ini sangat penting untuk diperhatikan.

Reaksi yang terjadi jika dilakukan titrasi dengan $\mathrm{pH}<6,5$ : $2 \mathrm{H}_{(a q)}^{+}+2 \mathrm{CrO}_{4}^{2-}{ }_{(a q)} \leftrightarrow 2 \mathrm{HCrO}_{4(a q)} \leftrightarrow \mathrm{Cr}_{2} \mathrm{O}_{7}^{2-}{ }_{(a q)}+$
$\mathrm{H}_{2} \mathrm{O}_{(l)}$

Kondisi di atas dapat menyebabkan konsentrasi ion kromat akan terlalu kecil(sedikit) untuk memungkinkan terjadinya endapan $\mathrm{Ag}_{2} \mathrm{CrO}_{4}$. Akibat dari kecilnya konsentrasi dari ion kromat akan menyebabkan kesulitan dalam menentukan titik akhir titrasi. Oleh sebab itu, pada analit yang memiliki sifat asam perlu untuk ditambahkan dengan kalsium karbonat agar $\mathrm{pH}$ tepat pada kisaran 6,5-10. Selain dengan penambahan kalsium karbonat juga dapat dilakukan dengan penambahan padatan natrium hidrogen karbonat yang akan membuat $\mathrm{pH}$ larutan menjadi naik dengan kisaran $\mathrm{pH}$ 6,5-10. Sebaliknya jika titrasi argentometri dengan metode Mohr ini dilakukan pada $\mathrm{pH}>10$, maka ion $\mathrm{Ag}^{+}$akan bereaksi dengan ion $\mathrm{OH}^{-}$membentuk endapan $\mathrm{AgOH}$ yang berwarna kecoklatan. Endapan tersebut akan mempersulit dalam pengamatan saat titik akhir titrasi berlangsung. 
Reaksi yang terjadi jika dilakukan titrasi dengan $\mathrm{pH}>10$ :

$$
\mathrm{Ag}_{(a q)}^{+}+\mathrm{OH}_{(a q)}^{-} \leftrightarrow \mathrm{AgOH}_{(s)}
$$

Melakukan pengadukan pada saat penambahan larutan standar akan mempermudah pengamatan saat tercapainya titik akhir titrasi. Selain hal tersebut sebelum titik akhir titrasi tercapai, pengadukan juga akan menyebabkan endapan perak kromat akan terurai atau larut kembali. Hal lain yang perlu diperhatikan dalam titrasi argentometri metode Mohr ini yaitu saat larutan perak nitrat dan endapan perak klorida yang terbentuk harus jauh dari paparan sinar matahari sebab perak klorida dapat terdekomposisi menjadi logam perak dan klor.

Menurut reaksi :

\section{$2 \mathrm{AgCl}_{(s)} \rightarrow 2 \mathrm{Ag}_{(s)}+\mathrm{Cl}_{2(g)}$}

Kedua hal yang telah dikemukakan di atas akan mempengaruh ketepatan dan kecermatan hasil analisis. Oleh sebab itu, maka perlu dibutuhkan larutan blanko pada saat melakukan titrasi argentometri ini. Larutan blanko untuk mengoreksi hasil dari titrasi yang telah dilakukan. Larutan blanko diperlukan dengan menggunakan metode yang sama selama analisis akan tetapi tanpa larutan analit.

Sebelum dilakukan untuk menentukan kuantitas analit, larutan perak nitrat yang merupakan larutan standar sekunder terlebih dahulu dilakukan standarisasi untuk mengetahui konsentrasi dari larutan tersebut. Standarisasi oleh larutan perak nitrat dapat dilakukan menggunakan larutan natrium klorida standar. 
Gambar 4.1 Perubahan warna yang terjadi pada titrasi argentometri metode Mohr

\section{b. Metode Volhard}

Titrasi argentometri metode Volhard ini indikator yang digunakan yaitu $\mathrm{Fe}(\mathrm{III})$ atau ion $\mathrm{Fe}^{3+}$ dan ion tiosianat( $\left.\mathrm{SCN}^{-}\right)$ bertindak sebagai larutan standar. Titik akhir titrasi pada metode Volhard ini ditandai dengan perubahan warna putih menjadi merah. Titrasi dengan metode ini merupakan titrasi langsung terhadap $\mathrm{Ag}^{+}$serta merupakan titrasi balik terhadap ion klorida, bromida dan iodida. Penambahan $\mathrm{AgNO}_{3}$ dalam jumlah tertentu dan berlebih, kemudian kelebihan larutan perak nitrat $\left(\mathrm{AgNO}_{3}\right)$ tersebut akan dititrasi dengan larutan standar ion tiosianat $\left(\mathrm{SCN}^{-}\right)$. Setelah titik ekivalen berlangsung, penambahan ion tiosianat $\left(\mathrm{SCN}^{-}\right)$ini akan bereaksi dengan indikator $\mathrm{Fe}(\mathrm{III})$ membentuk ion kompleks yang berwarna merah. Dan saat perubahan warna inilah titrasi harus segera dihenmtikan karna sudah mencapai titik akhir titrasi.

Reaksi yang terjadi pada titrasi argentometri ini dengan menggunakan metode Volhard yaitu sebagai berikut :

$$
\begin{aligned}
& \mathrm{Ag}_{(\text {aq) berlebih }}^{+}+\mathrm{Cl}_{(\text {aq) }}^{-} \rightarrow \mathrm{AgCl}_{(s)} \text { (putih) } \\
& \mathrm{Ag}_{(\text {aq) sisa }}^{+}+\mathrm{SCN}_{(a q)}^{-} \rightarrow \mathrm{AgSCN}_{(s)} \text { (putih) }
\end{aligned}
$$




\section{$\mathrm{Fe}_{(a q)}^{3+}+\mathrm{SCN}_{(a q)}^{-} \rightarrow \mathrm{Fe}(\mathrm{SCN})^{2+}$ (kompleks berwarna merah)}

Titrasi argentometri dengan menggunakan metode Volhard ini iasanya disebut sebagai titrasi balik atau titrasi kembali. Mol analit ditentukan dari pengurangan jumlah mol perak yang ditambahkan dengan mol larutan standar tiosianat. Seperti larutan perak nitrat, larutan tiosianat juga harus dilakukan standarisasi terlebih dahulu menggunakan perak nitrat standar yang digunakan untuk mengetahui konsentrasi atau kadar dari larutan tiosianat tersebut.

Gambar 4.2 Perubahan warna yang terjadi pada titrasi argentometri metode Volhard

\section{c. Metode Fajans}

Pada titrasi argentometri menggunakan metode Fajans ini menggunakan indikator yang disebut dengan indikator adsorpsi. Indikator adsorpsi ini merupakan senyawa organik yang dapat berubah warnanya jika teradsorpsi pada permukaan endapan. Misalnya titrasi antara ion klorida dengan larutan standar $\mathrm{Ag}^{+}$, yang reaksinya :

$$
\mathrm{Ag}_{(a q)}^{+}+\mathrm{Cl}_{(a q)}^{-} \rightarrow \mathrm{AgCl}_{(s)} \text { (putih) }
$$


Titrasi tersebut menunjukkan proses adsorpsi dengan menggunakan indikator yang bermuatan negatif seperti fluoroscein $\left(\mathrm{Fl}^{-}\right)$. Saat sebelum tercapai titik ekivalen larutan tersebut memiliki $\mathrm{Cl}^{-}$yang berlebih, sehingga indikator fluoroscein $\left(\mathrm{Fl}^{-}\right)$tidak teradsorpsi pada permukaan endapan yang menyebabkan permukaan endapan masih diselimuti oleh ion $\mathrm{Cl}^{-}$yang bebas akibatnya antara endapan dengan $\mathrm{Fl}^{-}$saling tolak menolak.

Reaksinya adalah :

\section{$(\mathrm{AgCl}) \mathrm{Cl}^{-}+\mathrm{Fl}^{-} \rightarrow$ tidak ada adsorpsi}

Endapan akan bersifat netral pada saat titik ekivalen berlangsung, karena pada saat titik ekivalen berlangsung ion $\mathrm{Cl}^{-}$ maupun $\mathrm{Ag}^{+}$tidak ada lagi dipermukaan endapan. Hilangnya kedua ion tersebut akibat adanya reaksi yang berlangsung. Penambahan sejumlah kecil ion $\mathrm{Ag}^{+}$pada saat setelah titik ekuivalen berlangsung akan menyebabkan lebihnya jumlah muatan ion $\mathrm{Ag}^{+}$didalam larutan tersebut, sehingga pada permukaan endapan hanya terdapat ion $\mathrm{Ag}^{+}$dan $\mathrm{Fl}^{-}$. Ion $\mathrm{Fl}^{-}$ akan teradsopsi pada permukaan endapan melalui gaya elektrostatis. Gaya elektrostatis merupakan gaya yang timbul yang memiliki muatan listrik statik. Jika muantan yang dimiliki sama atau sejenis maka akan saing tolak menolak tetapi jika muatan yang dimiliki berlawanan jenis maka akan saling tarik menarik. Adanya ion $\mathrm{Fl}^{-}$yang teradsorpsi ini mengakibatkan terjadinya perubahan warna indikator.

dengan reaksi :

$(\mathrm{AgCl}) \mathrm{Ag}^{+}+\mathrm{Fl}^{-} \rightarrow(\mathrm{AgCl})\left(\mathrm{Ag}^{+} \mathrm{Fl}^{-}\right)$ 
Semua indikator adsorpsi dapat teradsopsi pada permukaan endapan karena indikator adsorpsi bersifat ionik. Ion sulfat dengan ion barium dalam pelarut aseton yaitu thorin atau alizarin yang merupakan indikator adsorpsi yang sering digunakan untuk proses penitrasian.

Gambar 4.3 Mekanisme adsorbsi pada metode Fajans

Penggunaan indikator adsorpsi ini memiliki keuntungan yaitu memiliki galat yang kecil dalam penentuan titik akhir titrasi dan pada saat titik akhir titrasi berlangsung perubahan warna dapat diamati dengan jelas. Indikator ini saat digunakan pada saat titrasi argentometri menghasilkan endapan yang luas permukaan yang besar, sehingga indikator dapat teradsorpsi dengan baik. Jenis indikator adsorpsi dan penggunaannya :

Tabel 4.1 Indiaktor Adsorbsi dan Penggunaannya

\begin{tabular}{|l|l|l|}
\hline \multicolumn{1}{|c|}{ Indikator } & \multicolumn{1}{|c|}{ Titrasi } & Kondisi Larutan \\
\hline Fluorescein & $\mathrm{Cl}^{-}$dengan $\mathrm{Ag}^{+}$ & $\mathrm{Ph} \mathrm{7-8}$ \\
\hline Diklorofluorescein & $\mathrm{Cl}^{-}$dengan $\mathrm{Ag}^{+}$ & \\
\hline Bromkresol hijau & $\mathrm{SCN}^{-}$dengan $\mathrm{Ag}^{+}$ & $\mathrm{pH} \mathrm{4-5}$ \\
\hline Eosin & $\begin{array}{l}\mathrm{Br}^{-}, \quad \mathrm{I}^{-}, \mathrm{SCN}^{-} \\
\text {dengan } \mathrm{Ag}^{+}\end{array}$ & $\mathrm{pH} \mathrm{2}$ \\
\hline
\end{tabular}




\begin{tabular}{|l|l|l|}
\hline Metil ungu & $\mathrm{Ag}^{+}$dengan $\mathrm{Cl}^{-}$ & Larutan asam \\
\hline Rhodamin 6 G & $\mathrm{Ag}^{+}$dengan $\mathrm{Cl}^{-}$ & $\mathrm{HNO}_{3}(0,3 \mathrm{M})$ \\
\hline Thorin & $\mathrm{SO}_{4}{ }^{2-}$ dengan $\mathrm{Ba}^{2+}$ & $\mathrm{Ph} \mathrm{1,5-3,5}$ \\
\hline Bromfenol biru & $\mathrm{Hg}^{2+}$ dengan $\mathrm{Cl}^{-}$ & Larutan 0,1 M \\
\hline Ortokrom T & $\begin{array}{l}\mathrm{Pb}^{2+} \\
\mathrm{CrO}_{4}{ }^{2-}\end{array}$ & $\begin{array}{l}\text { Netral, larutan } \\
0,02 \mathrm{M}\end{array}$ \\
\hline
\end{tabular}

Contoh struktur molekul dari indikator adsorpsi :

Gambar 4.4 Struktur Molekul Indikator Adsorbsi

Gambar 4.5 Perubahan warna yang terjadi pada titrasi argentometri metode Fajans

\section{b. Penentuan Titik Akhir Titrasi}

Berikut merupakan penentuan titik akhir titrasi:

\section{a. Pembentukan Suatu Endapan Berwarna}

Sebagai contoh pada metode Mohr untuk penetapan klorida dan bromide. Larutan kalium kromat ditambahkan sedikit pada suatu larutan netral dari ion klorida dengan larutan perak nitrat. Penambahan sedikit larutan kalium kromat ini 
berfungsi sebagai indikator pada larutan tersebut. Saat titik akhir titrasi berlangsung ion kromat dengan ion perak akan membentuk endapan perak kromat yang berwarna merah. Dalam titrasi menggunakan metode Mohr ini hendaknya dilakukan pada suasana yang netral atau sedikit basa yaitu $\mathrm{pH}$ sekitar 6,59.

\section{b. Pembentukan Suatu Senyawaan Berwarna yang dapat Larut}

Metode Volhard digunakan sebagai contoh dalam prosedur ini, titrasi dengan adanya perak yaitu asam nitrat bebas dengan larutan standar kaliun atau ammonium tiosianat dan sebagai indikatornya digunakan $\mathrm{Fe}^{3+}$. Saat penambahan larutan standar tiosianat awalnya akan menghasilkan endapan perak klorida. Kelebihan larutan tiosianat akan dapat menghasilkan larutan kompleks yang berwarna coklat kemerahan.

$$
\begin{aligned}
\text { Reaksinya : } \mathrm{Ag}^{+}+\mathrm{SCN}^{-} \rightarrow \mathrm{AgSCN} \\
\mathrm{Fe}^{3+}+\mathrm{SCN}^{-} \rightarrow \mathrm{FeSCN}^{2+}
\end{aligned}
$$

Metode ini dapat juga digunakan untuk penetapan klorida, bromide dan iodide dalam larutan asam. Ditambahkan secara berlebih larutan standar perak nitrat dan kelebihannya dititrasi lagi dengan larutanm standar tiosianat.

$$
\begin{array}{ll}
\text { Reaksi : } \quad \mathrm{Ag}^{+}+\mathrm{Cl}^{-} \rightarrow \mathrm{AgCl} \\
\\
\mathrm{Ag}^{+}+\mathrm{SCN}^{-} \rightarrow \mathrm{AgSCN}
\end{array}
$$




\section{c. Penggunaan Indikator Adsorpsi}

Dinamakan indikator adsorpsi karena pada saat terjadi titik ekuivalen, indikator itu diserap(diadsorpsi) oleh permukaan endapan tersebut dan selama proses itu suatu larutan akan mengalami perubahan dalam indikator yang menimbulkan adanya perubahan warna pada larutan tersebut. Zat yang digunakan yaitu zat-zat warna asam seperti, fluoresein yang digunakan sebagai garam natriumnya. Pada titrasi menggunakan perak klorida dengan larutan perak nitrat, perak klorida akan mengendap dan terjadi proses adsorpsi oleh ionion klorida dan ion fluoresein akan membentuk senyawa yang kompleks dari perak yang berwarna merah jambu.

Tabel 4.2 Perbedaan Metode pada Titrasi Argentometri

\begin{tabular}{|c|c|c|c|c|c|}
\hline Metode & Indikator & Suasana & $\begin{array}{c}\text { Metode } \\
\text { Reaksi }\end{array}$ & $\begin{array}{c}\text { Yang di } \\
\text { dalam } \\
\text { buret }\end{array}$ & $\begin{array}{c}\text { Titik } \\
\text { akhir } \\
\text { titrasi }\end{array}$ \\
\hline Mohr & $\mathrm{K}_{2} \mathrm{CrO}_{4}$ & Netral & Langsung & $\mathrm{AgNO}_{3}$ & $\begin{array}{c}\text { Endapan } \\
\text { merah } \\
\text { bata }\end{array}$ \\
\hline Volhard & $\begin{array}{c}\mathrm{Fe}^{3+} / \mathrm{Fe} \\
\text { allum }\end{array}$ & Asam & $\begin{array}{c}\text { Tidak } \\
\text { langsung }\end{array}$ & $\mathrm{KCNS}$ & $\begin{array}{c}\text { Larutan } \\
\text { merah } \\
\text { bata }\end{array}$ \\
\hline Fajans & $\begin{array}{c}\text { Adsorpsi } \\
\text { (fluorescein) }\end{array}$ & Netral & Langsung & $\mathrm{AgNO}_{3}$ & $\begin{array}{c}\text { Larutan } \\
\text { pink }\end{array}$ \\
\hline
\end{tabular}

(Sumber : Day \& Underwood, 2001: 280) 
Berdsarkan tabel di atas dari ketiga metode tersebut yang paling stabil yaitu metode Volhard. Akan tetapi metode tersebut menggunakan larutan asam sianida(HCN) yang bersifat beracun(toxik).

\section{c. Rangkuman}

$>$ Titrasi argentometri adalah titrasi yang menggunakan larutan standar sekunder perak nitrat $\mathrm{AgNO}_{3}$.

$>$ titrasi argentometri dikenal terdapat 3 metode yaitu metode Mohr, metode Volhard, dan metode Fajans.

$>$ metode Mohr ini indikator yang digunakan yaitu kalium kromat $\left(\mathrm{K}_{2} \mathrm{CrO}_{4}\right)$. Dengan perubahan warna yang terjadi saat titrasi yaitu dari kuning muda $\rightarrow$ putih $\rightarrow$ merah bata.

$>$ Titrasi argentometri metode Volhard ini indikator yang digunakan yaitu $\mathrm{Fe}(\mathrm{III})$ atau ion $\mathrm{Fe}^{3+}$ dan ion tiosianat $\left(\mathrm{SCN}^{-}\right)$bertindak sebagai larutan standar.

$>$ Titik akhir titrasi pada metode Volhard ini ditandai dengan perubahan warna putih menjadi merah.

$>$ Titrasi argentometri menggunakan metode Fajans ini menggunakan indikator yang disebut dengan indikator adsorpsi.

\section{d. Latihan Soal}

Sebagai sarana Anda dalam memahami materi Titrasi Argentometri, jawablah soal di bawah ini secara sistematis!

1. Apa yang Anda ketahui tentang titrasi Argentometri?

2. Jelaskan prinsip dari titrasi Argentometri! 
3. Jelaskan perbedaan dari titrasi argentometri dengan metode Mohr, Volhard, dan Fajans!

4. Mengapa indikator yang digunakan pada titrasi argentometri dengan metode Mohr, Volhard, dan Fajans berbeda?

5. Jenis sampel yang bagaimanakah yang dapat dianalisis dengan titrasi argentometri metode Mohr, Volhard, dan Fajans!

\section{BAB 5}

\section{TITRASI KOMPLEKSOMETRI}

\section{Sub-Capaian Pembelajaran Mata Kuliah}

1. Mahasiswa mampu memahami analisis kompleksometri.

2. Mahasiswa mampu menjelaskan reaksi pembentukan kompleks dan definisi titrasi kompleksometri dengan memberikan contoh dan menuliskan persamaan reaksinya.

3. Mahasiswa mampu melakukan titrasi kompleksometri dan menentukan titik akhir dari kurva titrasi.

4. Mahasiswa mampu membedakan reaksi pengendapan dengan reaksi pembentukan kompleks.

\subsection{Reaksi Pembentukan Kompleks}

Sebagian besar dari ion logam merupakan golongan yang memiliki kemampuan untuk bereaksi dengan pasangan elektron dari suatu golongan ligan lainnya. Reaksi ini dapat disebut sebagai reaksi kompleksasi. Golongan ligan tersebut dapat berupa ion atau molekul yang memiliki kemampuan untuk membentuk ikatan kovalen dengan suatu kation atau atom logam netral lainnya, 
dengan cara menyalurkan sebuah pasangan elektron untuk kemudian digunakan bersama. Jumlah ikatan kovalen yang terbentuk dikenal dengan bilangan koordinasi.

Reaksi kompleks ini melibatkan penggantian satu atau lebih molekul pelarut yang terkoordinasi dengan gugus nukleofilik lain. Di dalam suatu larutan, reaksi dapar digambarkan sebagai :

$$
M\left(\mathrm{H}_{2} \mathrm{O}\right)_{n}+L \leftrightarrow M\left(\mathrm{H}_{2} \mathrm{O}\right)_{(n-1)} L+\mathrm{H}_{2} \mathrm{O}
$$

Adanya penggantian secara berturut terhadap molekul didalam air oleh gugus ligan dapat berlangsung secara terus menerus sampai membentuk senyawa kompleksML $\mathrm{ML}_{n}$. Indeks $\mathrm{n}$ merupakan bilangan koordinasi dari senyawa kompleks dan menggambarkan jumlah maksimum ligan monodentat yang berikat.

Suatu ligan monodentat merupakan ligan dengan sebuah pasangan elektron yang disalurkan pada golongan ligan lainnya. Dengan cara membedakan jumlah pasangan elektron bebas yang dimilikinya dan akan disalurkan ke golongan penerima yang dapat dibedakan adanya ligan bidentat, tridentat dan seterusnya yang termasuk dalam golongan ligan polidentat. Senyawa kompleks dengan bilangan koordinasi 6 seperti senyawa kompleks dari kation Co (III) dibentuk dari koordinasi dengan molekul EDTA (bidentat). Tiap molekul dari senyawa EDTA berikatan dengan ion logam melalui pasangan elektron bebas dari dua atom nitrogen molekul tersebut. Dalam proses ini menghasilkan 3 cincin dengan masingmasing memiliki 5 ion logam pusat. Proses pembentukan cincin ini disebut dengan chelation dan ligan yang bertindak sebagai pembentukan disebut dengan pengkelat. 
Senyawa kompleks dapat mengandung lebih dari satu jenis ion logam pusat. Seperti senyawa kompleks binuclear memiliki dua ion logam atau dapat mengandung lebih dari dua ion logam pusat (kompleks polynuclear). Proses pembentukan kompleks poliinti ini terjadi pada konsentrasi ion logam yang tinggi. Contohnya seperti interaksi dari ion $\mathrm{Zn}^{2+}$ dengan ion $\mathrm{Cl}^{-}$yang membentuk kompleks biinti $\left[\mathrm{Zn}_{2} \mathrm{Cl}_{6}\right]^{2-}$ disamping dengan golongan sederhana $\mathrm{ZnCl}_{3}^{-}$dan $\mathrm{ZnCl}_{4}{ }^{2-}$.

\subsection{Stabilitas Kompleks}

Merupakan stabilitas termodinamik dari suatu golongan yang dapat diukur dari seberapa golongan tersebut terbentuk dari golongan lain pada kondisi tertentu sampai mencapai kesetimbangan. Bila suatu ion logam $M$ berada dalam larutan dengan ligan monodentat L, maka dapat digambarkan dengan kesetimbangan berikut (untuk penyederhanaan sistem, molekul air yang terkoordinasi tidak dituliskan) :

$$
\begin{aligned}
& \mathrm{M}+\mathrm{L} \leftrightarrow \mathrm{ML} ; \quad \text { dengan } \mathrm{K}_{\mathbf{1}}=[\mathrm{ML}] /[\mathrm{M}][\mathrm{L}] \\
& \mathrm{ML}+\mathrm{L} \quad \leftrightarrow \mathrm{ML}_{2} ; \text { dengan } \mathrm{K}_{\mathbf{2}}=\left[\mathrm{ML}_{2}\right] /[\mathrm{ML}] /[\mathrm{L}] \\
& \left.\mathrm{ML}_{(\mathrm{n}-1)}+\mathrm{L} \leftrightarrow \mathrm{ML}_{\mathrm{n}} ; \text { dengan } \mathrm{K}_{\mathrm{n}}=\left[\mathrm{ML}_{\mathrm{n}}\right] /[\mathrm{ML}(9 \mathrm{n}-1)][\mathrm{L}]\right]
\end{aligned}
$$

Konstanta kesetimbangan $K_{1}, K_{2}$. . $K_{n}$ merupakan konstanta kesetimbangan bertahap. Cara alternatif dalam menggambarkan kesetimbangan kompleks yaitu :

$$
\mathrm{M}+\mathrm{L} \leftrightarrow \mathrm{ML} ; \text { dengan } \boldsymbol{B}_{1}=[\mathrm{ML}] /[\mathrm{M}][\mathrm{L}]
$$




$$
\begin{aligned}
& \mathbf{M}+\mathbf{2 L} \leftrightarrow \mathrm{ML}_{2} ; \text { dengan } \boldsymbol{B}_{2}=\left[\mathrm{ML}_{2}\right] /[\mathrm{ML}][\mathrm{L}]^{2} \\
& \mathrm{M}+\mathrm{nL} \leftrightarrow \mathrm{ML}_{\mathrm{n}} ; \text { dengan } \boldsymbol{B}_{3}=\left[\mathrm{ML}_{\mathrm{n}}\right] /[\mathrm{M}][\mathrm{L}]^{\mathrm{n}}
\end{aligned}
$$

Konstanta kesetimbangan $B_{1}, B_{2}$. . . $\mathbb{B}_{n}$ merupakan konstanta kesetimbangan overal(keseluruhan) dan memiliki hubungan dengan $\mathrm{K}$ sebagai :

$$
B_{n}=K_{1} \times K_{2} \times \ldots K_{n}
$$

dengan asumsi bahwa tidak ada produk reaksi yang tidak larut dan terbentuknya kompleks multiinti. Dari konstanta di atas sangat berguna dalam perhitungan konsentrasi golongan kompleks yang telah terbentuk oleh suatu logam dalam campuran kesetimbangan.

Faktor-faktor yang mempengaruhi stabilitas kompleks meliputi hal-hal berikut :

\section{a. Kemampuan Logam Membentuk Kompleks.}

Kemampuan logam membentuk senyawa kompleks ini telah digambarkan dengan klasifikasi Schwarzenbach. Pengkatagorian ini didasarkan pada penggolongan logam ke dalam larutan asam Lewis kelas A dan kelas B. Kelompok ion logam dari kelas $A$ dapat dibedakan berdasarkan urutan afinitas di dalam air(logam) terhadap ion halogen $\mathrm{F}^{\prime}>>\mathrm{Cl}^{-}>\mathrm{Br}^{\prime}>\mathrm{I}^{-}$serta pembentukan senyawa kompleks yang stabil dengan anggota pertama yaitu tiap golongan atom donor dalam tabel periodik(N, O dan F). Sedangkan kelompok pada ion kelas B bereaksi dengan $\mathrm{I}^{-}$dari $\mathrm{F}^{\prime}$ dalam larutan yang berair dan membentuk senyawa kompleks yang paling stabil dengan atom 
donor dua dari tiap golongan( $\mathrm{P}, \mathrm{S}$ dan $\mathrm{Cl}$ ). Klasifikasi dari Schwarzenbach membuat kategori ion logam akseptor :

$\checkmark$ Kation yang memiliki konfigurasi gas mulia. Logam alkali, alkali tanah dan aluminium termasuk golongan ini dan masuk kategori sifat akseptor kelas A

$\checkmark$ Kelompok kelas B yaitu kation-kation yang memiliki subkulit d yang terisi penuh. Kation-kation dalam golongan ini yaitu $\mathrm{Cu}(1), \operatorname{Ag}(1)$ dan $\mathrm{Au}(1)$. Kation tersebut memiliki karakter polarisasi yang kuat yang dapat mebentuk senyawa kompleks dengan karakter kovalen yang cukup kuat. Kompleks yang terbentuk dari kation tersebut semakin stabil bila konfigurasi elektron semakin mirip gas mulia dan semakin kurang elektronegatif atom donor ligan

$\checkmark$ Ion logam transisi dengan subkulit d yang kurang lengkap terisi elektron.

Konsep dari larutan asam basa keras dan lunak juga berguna dalam mengkarakterisasi perilaku dari kelompok kelas A dan kelas B. Basa lunak menggambarannya sebagai basa dengan atom donor yang sangat mudah terpolarisasi dan eletronegativitas yang rendah, mudah teroksidasi, terasosiasi dengan orbit kosong energi yang rendah. Dalam hal ini, elektron atom donor mudah terdistorsi. Sedangkan basa keras memiliki karakteristik yang berlawanan dengan basa lunak, yaitu atom donor kurang mampu dalam terpolarisasi dan memiliki elektronegativitas yang sangat tinggi dibandingkan dengan basa lunak, basa keras sulit untuk direduksi dan terasosiasi demngan orbit kosong energi yang tinggi. Atas dasar tinjauan dari konsep di atas, akseptor dari kelompok kelas A cenderung berikatan dengan basa keras dan kelompok kelas B sebaliknya. 
Akseptor dari kelompok kelas A menunjukkan karakter ukuran yang lebih kecil, tingkat oksidasi positif yang besar dan tidak adanya elektron lapisan luar yang tereksitasi dengan mudah ke tingkat energi yang lebih tinggi. Akseptor ini juga disebut dengan asam keras, yang kurang mampu terpolarisasi. Sedangkan asam lunak, memiliki karakter yang berlawanan dengan asam keras tersebut. Secara umum dapat dikemukakan bahwa asam keras berasosiasi dengan basa keras dan asam lunak dengan basa lunak.

\section{b. Karakteristik Logam.}

Berikut merupakan karakteristik logam :

$\checkmark$ Kekuatan basa ligan

$\checkmark$ Sifat pengkelat

$\checkmark$ Efek sterik

Dari ketiga karakteristik di atas, karakter pengkelat memiliki peran yang menonjol dalam aplikasi analisis. Kompleks dalam bentuk pengkelat ini memiliki faktor stabilitas yang jauh lebih baik daripada kompleks tanpa pengkelat lainnya.

\subsection{Titrasi Pembentukan Senyawa Kompleks}

Terdapat beberapa jenis ligan (titran) yaitu ligan monodentat dan ligan polidentat. Titrasi pembentukan senyawa kompleks ini digolongan berdasarkan jenis ligannya yang terdiri atas 


\section{a. Titrasi yang melibatkan ligan monodentat}

Jenis ligan monodentat ini sangat jarang dipergunakan sebagai titran dalam suatu titrasi. Tetapi terdapat dua jenis ligan monodentat yang dapat digunakan dalam titrasi kompleksometri ini yaitu, sianida dengan ion perak yang dikenal sebagai metode titrasi Liebig dan ion klorida dengan merkuri(III).

\section{- Titrasi Ion Sianida dengan Ion Perak}

Titrasi ini dikenal dengan sebutan titrasi Liebig. Analisis kimia dengan menggunakan metode Liebig ini dapat dilakukan dengan penambahan sedikit demi sedikit larutan perak nitrat ke dalam larutan yang mengandung sianida. Awalnya akan terlihat endapan putih pada larutan, endapan putih ini berasal dari perak sianida yang larut dan membentuk kompleks disianoargentat(I). Berikut reaksinya :

$$
\mathrm{AgCN}_{(s)}+\mathrm{CN}_{(a q)}^{-} \leftrightarrow \mathrm{Ag}(\mathrm{CN})_{2}^{-}{ }_{(a q)}^{-}
$$

Apabila kedua reaksi tersebut dijumlahkan, maka reaksi yang terjadi yaitu :

$$
\mathrm{Ag}_{(a q)}^{+}+2 \mathrm{CN}_{(a q)}^{-} \leftrightarrow \mathrm{Ag}(\mathrm{CN})_{2}^{-}{ }_{(a q)}
$$

Pada titrasi di atas terjadi reaksi yang sempurna antara ion perak dengan ion sianida, setelahnya kelebihan ion perak akan bereaksi dengan senyawa $\mathrm{Ag}(\mathrm{CN})_{2}{ }^{-}$yang akan membentuk endapan perak disiano argentat yang berwarna putih, reaksi yang terjadi :

$$
\mathrm{Ag}^{+}+\mathrm{Ag}(\mathrm{CN})_{2}{ }^{-} \leftrightarrow A g\left[\mathrm{Ag}(\mathrm{CN})^{2}\right]_{(s) p u t i h}
$$




\section{$\mathrm{Ag}^{+}+\mathrm{Ag}(\mathrm{CN})_{2}{ }^{-} \leftrightarrow 2 \mathrm{AgCN}_{(s)}$}

Adanya endapan berwarna putih dari lebihnya ion perak yang bereaksi dengan $\mathrm{Ag}(\mathrm{CN})_{2}{ }^{-}$tersebut merupakan indikasi bahwa telah tercapainya titik ekivalen yang mengharuskan praktikan menghentikan titrasinya. Tetapi adanya endapan dari perak sianida sukar untuk diamati dengan jelas, maka metode Liebig ini dimodifikasi oleh Deniges. Modifikasi yang dimaksutkan oleh Deniges yaitu adanya penambahan ion iodida yang bertindak sebagai indikator. Permasalahan baru yang kemudian timbul yaitu endapan dari perak iodida mudah untuk diamati dan kurang larut dibandingkan dengan perak sianida $\left(\mathrm{Ksp} \mathrm{AgI}=1 \times 10^{-16}\right.$ dan $\mathrm{Ksp} \operatorname{Ag}\left[\operatorname{Ag}(\mathrm{CN})_{2}\right]=2 \times 10^{-12}$ yang menunjukkan bahwa titik akhir titrasi muncul lebih awal. Untuk menanggulangi masalah tersebut dapat ditambahkan amonia untuk membentuk kompleks $\mathrm{Ag}\left(\mathrm{NH}_{3}\right)_{2}{ }^{+}$. Adanya ion kompleks $\mathrm{Ag}\left(\mathrm{NH}_{3}\right)_{2}{ }^{+}$akan dapat memperlambat pengendapan dari perak iodida sampai waktu yang sesuai. Keberadaan amonia ini tidak mencegah terbentuknya senyawa kompleks dari $\mathrm{Ag}(\mathrm{CN})_{2}{ }^{-}$ karena ion kompleks ini lebih stabil dan tidak akan mengganggu proses reaksi saat titrasi. Reaksinya meliputi :

$$
\begin{gathered}
\mathrm{Ag}\left[\mathrm{Ag}(\mathrm{CN})_{2}\right]_{(s)}+2 \mathrm{NH}_{3(\mathrm{~g})} \leftrightarrow 2 \mathrm{Ag}\left(\mathrm{NH}_{3}\right)_{2}{ }_{(\mathrm{aq})} \\
\mathrm{Ag}\left(\mathrm{NH}_{3}\right)_{2}{ }_{(\mathrm{aq})}+{\mathrm{I}^{-}(\mathrm{aq})} \leftrightarrow \mathrm{AgI}_{(\mathrm{s})}+2 \mathrm{NH}_{3(\mathrm{aq})}
\end{gathered}
$$

\section{Kuning pucat}

Terbentuknya endapan berwarna kuning pucat dari perak iodida menunjukkan titik akhir titrasi. 


\section{- Titrasi Ion Perak dengan Merkuri(III)}

Merkuri(II) atau raksa(II) dapat dengan mudah bereaksi dengan jenis-jenis anion seperti ion halida, sianida dan tiosianat. Reaksi dari ion $\mathrm{Hg}^{2+}$ dengan ion $\mathrm{Cl}^{-}$akan membentuk ion kompelks berupa $\mathrm{HgCl}_{4}{ }^{2-}$. Dalam membentuk senyawa yang kompleks tersebut dilakukan dengan bertahap. Berdasarkan dari nilai konstanta kesetimbangan yang dikandung setiap tahapan, maka dua kompleks terakhir jauh kurang stabil dibandingkan dengan dua kompleks diawal. Hal tersebut dapat dilihat dari tahapan pembentukan kompleks, yaitu :

$$
\begin{array}{ll}
\mathrm{Hg}^{2+}+\mathrm{Cl}^{-} \leftrightarrow \mathrm{HgCl}^{+} & \mathrm{K}_{1}=5,5 \times 10^{6} \\
\mathrm{HgCl}^{+}+\mathrm{Cl}^{-} \leftrightarrow \mathrm{HgCl}_{2} & \mathrm{~K}_{2}=3,05 \times 10^{6} \\
\mathrm{HgCl}_{2}+\mathrm{Cl}^{-} \leftrightarrow \mathrm{HgCl}_{3} & \mathrm{~K}_{3}=7,1 \\
\mathrm{HgCl}_{3}+\mathrm{Cl}^{-} \leftrightarrow \mathrm{HgCl}_{4}{ }^{2-} & \mathrm{K}_{4}=10
\end{array}
$$

Dalam titrasi klorida dengan merkuri ini menggunakan indikator natrium nitroprusida $\left(\mathrm{Na}_{2} \mathrm{Fe}(\mathrm{CN})_{5} \mathrm{NO}\right)$. Penggunaan indikator natrium nitroprusida $\left(\mathrm{Na}_{2} \mathrm{Fe}(\mathrm{CN})_{5} \mathrm{NO}\right)$ ini akan membentuk endapan yang berwarna putih yang berasal dari merkuri nitroprusida. Endapan putih ini menunjukkan telah tercapainya titik ekivalen pada titrasi. Indikator natrium nitroprusida ini tidak dapat digunakan pada titrasi tiosianat karena endapan dari merkuri(II)nitroprusida ini dapat sedikit larut yang menyebabkan sukar untuk diamati. Permasalahan tersebut dapat di atasi menggunakan indikator ion $\mathrm{Fe}^{3+}$. Ion $\mathrm{Fe}^{3+}$ 
ini dapat bereaksi dengan ion $\mathrm{SCN}^{-}$yang akan membentuk ion kompleks berwarna merah berupa $\mathrm{FeSCN}^{2+}$.

Senyawa organik lain yang dapat digunakan dalam titrasi merkuri(II) ini yaitu difenilkarbasida yang tidak memiliki warna dan difenilkarbazon yang memiliki warna oranye yang akan membentuk senyawa kompleks berupa merkuri(II) yang berwarna ungu. Dalam penggunaan kedua indikator tersebut perlu diperhatikan pH larutannya. Menurut Roberts(dalam Day dan Underwood, 2002:218) , difenilkarbasida bekerja optimum pada $\mathrm{pH}$ 1,5-2,0. Sedangkan menurut Clark(dalam Day dan Underwood,2001), difenilkarbazon baik digunakan pada kisaran $\mathrm{pH} 3,2-3,3$.

\section{b. Titrasi yang Melibatkan Ligan Polidentat}

Contoh dari ligan polidentat ini yaitu EDTA(Ethylene Diamine Tetraacetic Acid). EDTA ini banyak digunakan dalam titrasi kompleksometri. Reaksi antara EDTA dengan ion logam berlangsung dalam satu tahapan dengan pembentukan ion kompleks yang memiliki perbandingan 1:1. Adapun prosedur yang dapat digunakan dalam titrasi dengan EDTA yaitu :

\section{- Titrasi Langsung}

Dalam titrasi langsung ini, larutan EDTA dapat digunakan untuk titrasi langsung dengan ion logam serta larutan EDTA ini dapat digunakan untuk beberapa jenis kation. Untuk mencegah pengendapan dari hidroksida logam perlu adanya penambahan bahan pengompleks seperti halnya sitrat dan tartrat. Selain itu juga dapat ditambahkan dengan larutan penyangga $\mathrm{NH}_{3}-\mathrm{NH}_{4} \mathrm{Cl}$ yang memiliki $\mathrm{pH}$ berkisar 9-10 untuk logam yang dapat membentuk senyawa kompleks dengan amonia. Indikator yang dapat dipergunakan yaitu indikator EBT 
(Eriochrome Black T) untuk titrasi dengan ion $\mathrm{Mg}, \mathrm{Zn}, \mathrm{Ca}$ dan $\mathrm{Cd}$ dan indikator murexide untuk titrasi dengan ion logam $\mathrm{Co}, \mathrm{Cu}$ dan Ni.

Titrasi yang menggunakan larutan EDTA biasanya yaitu titrasi untuk menentukan kesadahan air. Air sadah mengandung ion kalsium dan magnesium. Ion dari magnesium ini dapat membentuk senyawa yang kompleks yang lebih kuat dengan indikator EBT dibandingkan dengan ion kalsium. Oleh sebab itu, warna dari kompleks magnesium lebih mudah untuk diamati. Titrasi ini sebaiknya dilakukan dalam kisaran pH 10 dengan menggunakan larutan buffer.

Reaksi yang terjadi yaitu :

$$
\mathrm{Ca}_{(a q)}^{2+}+\mathrm{H}_{2} \mathrm{Y}_{(a q)}^{2-} \rightarrow \mathrm{CaY}^{2-}{ }_{(a q)}+2 \mathrm{H}_{(a q)}^{+} \mathrm{Kf}=10^{10,7}
$$

Apabila sampel yang akan dititrasi dengan larutan EDTA tidak mengandung magnesium, maka dapat dilakukan dengan penambahan garam magnesium pada larutan EDTA tersebut sebelum dilakukannya standarisasi.

Reaksi yang terjadi yaitu :

$$
\mathrm{Mg}_{(a q)}^{2+}+\mathrm{H}_{2} \mathrm{Y}_{(a q)}^{2-} \rightarrow \mathrm{MgY}_{(a q)}^{2-}+2 \mathrm{H}_{(a q)}^{+} \mathrm{Kf}=10^{8,7}
$$

Dengan demikian titran ini merupakan campuran dari $\mathrm{MgY}^{2-}$ dan $\mathrm{Y}^{4-}$. Ketika campuran tersebut ditambahkan pada larutan yang mengandung ion $\mathrm{Ca}^{2+}$ akan membentuk ion $\mathrm{CaY}^{2-}$ yang lebih stabil, dengan adanya pembebasan ion $\mathrm{Mg}^{2+}$ yang 
akan bereaksi dengan indikator EBT akan membentuk senyawa MgIn- yang berwarna merah. Setelah kalsium telah habis, maka berikutnya penambahan volume titran akan mengubah $\mathrm{MgIn}^{-}$ menjadi $\mathrm{MgY}^{2-}$ dan indikator akan berubah menjadi $\mathrm{HIn}^{2-}$ yang akan berwarna biru.

Reaksi yang terjadi :

$$
M g_{(a q)}^{2+}+E B T_{(a q)} \leftrightarrow M g E B T_{(a q)} \quad \mathrm{Kf}=10^{7}
$$

\section{- Titrasi Balik}

Titrasi balik atau juga bisa disebut dengan titrasi mundur atau titrasi kembali. Titrasi ini digunakan ketika adanya reaksi antara kation dengan EDTA yang berjalan lambat atau tidak adanya indikator logam yang sesuai dengan titrasi. Pada titrasi balik ini, larutan sampel ditambahkan dengan larutan EDTA dalam jumlah tertentu dan berlebih serta ditambahkan juga dengan larutan penyangga. Sejumlah larutan EDTA yang tidak dapat bereaksi dengan larutan sampel kemudian dititrasi menggunakan larutan standar(seng klorida/seng sulfat). Adapun larutan standar lain yang dapat digunakan yaitu magnesium klorida atau magnesium sulfat. Metode juga dapat digunakan untuk menentukan logam-logam dalam pengendapan, contohnya yaitu timbal dalam timbal sulfat dan kalsium dalam kalsium oksalat.

\section{- Titrasi Penggantian atau Titrasi Substitusi}

Titrasi ini digunakan ketika tidak ada indikator yang sesuai pada titrasi dengan reaksi kation dengan EDTA. Larutan kompleks dari Mg-EDTA dengan jumlah yang telah ditetapkan 
dan dalam kondisi berlebih akan ditambahkan ke larutan yang terdapat dalam erlenmeyer(analit) yang memiliki kandungan kation (ion logam) tertentu. Kemudian ion logam berupa $\mathrm{M}^{2+}$ akan menggantikkan magnesium yang terkandung dari senyawa kompleks EDTA yang lebih lemah.

Reaksi yang berlangsung yaitu :

$$
M^{2+}+M g Y^{2-} \leftrightarrow M Y^{2-}+M g^{2+}
$$

Dari reaksi di atas, jumlah ion dari $\mathrm{Mg}^{2+}$ yang telah dibebaskan sebanding dengan jumlah ion logam tersebut. Selanjutnya ion $\mathrm{Mg}^{2+}$ akan dititrasi menggunakan larutan EDTA dengan kalmagit yang bertindak sebagai indikatornya.

\section{- Titrasi Tidak Langsung}

Titrasi tidak langsung ini telah banyak digunakan untuk titrasi penentuan anion yang mengendap dengan kation logam tertentu. Misalnya, penentuan ion sulfat $\left(\mathrm{SO}_{4}{ }^{2-}\right), \mathrm{SO}_{4}{ }^{2-}$ ditambahkan dengan ion barium yang berlebih untuk mengendapkan barium sulfat pada $\mathrm{pH} 1$. Kemudian endapan tersebut disaring dan dicuci. Sisa larutan dari ion barium dititrasi menggunakan larutan EDTA. Terdapat anion yang lain yang dapat ditentukan dengan titrasi ini, yaitu ion karbonat $\left(\mathrm{CO}_{3}{ }^{2-}\right)$, kromat $\left(\mathrm{CrO}_{4}{ }^{2-}\right)$ dan sulfida $\left(\mathrm{S}^{2-}\right)$.

\section{- Titrasi Alkalimetri}

Titrasi ini dilakukan dengan menambahkan larutan standar berupa $\mathrm{Na}_{2} \mathrm{H}_{2} \mathrm{Y}$ (dinatrium etilendiaamintetraasetat) ke larutan yang telah mengandung ion logam untuk terjadi 
pembentukan ion kompleks dengan membebaskan 2 mol ion $\mathrm{H}^{+}$.

Reaksinya yaitu :

$$
M^{n^{*}}+H_{2} Y^{2^{-}} \leftrightarrow(M Y)^{(n-4)}+2 H^{+}
$$

Ion $\mathrm{H}^{+}$yang telah dibebaskan kemudian dititrasi dengan menggunakan larutan standar basa dengan menambahkan indikator asam basa.

\subsection{Rangkuman}

$>$ Titrasi kompleksometri merupakan titrasi pembentukan senyawa kompleks.

$>$ Golongan ligan tersebut dapat berupa ion atau molekul yang memiliki kemampuan untuk membentuk ikatan kovalen dengan suatu kation atau atom logam netral lainnya, dengan cara menyalurkan sebuah pasangan elektron untuk kemudian digunakan bersama. Jumlah ikatan kovalen yang terbentuk dikenal dengan bilangan koordinasi.

> Stabilitas kompleks merupakan stabilitas termodinamik dari suatu golongan yang dapat diukur dari seberapa golongan tersebut terbentuk dari golongan lain pada kondisi tertentu sampai mencapai kesetimbangan.

$>$ Jenis ligan (titran) yaitu ligan monodentat dan ligan polidentat. 


\subsection{Latihan Soal}

\section{Kerjakanlah soal di bawah ini!}

1. Buatlah kurva titrasi dari $60,0 \mathrm{~mL}$ larutan $\mathrm{Mg}^{2+} 0,05$

$\mathrm{M}$ dengan larutan EDTA 0,05 M pada pH 7 dan 10.

Tentukan letak titik ekivalensi bagi tiap kurva!

Reaksi $\mathrm{Mg}^{2+}+\mathrm{Y}^{4-} \rightarrow \mathrm{MgY}^{2-} \mathrm{K}_{\mathrm{tb}}=4,9 \times 10^{8}$.

2. Cangkang telur dikeringkan dan ditimbang sebesar

4,3215 g. Kemudian dilarutkan dengan $20 \mathrm{~mL} \mathrm{HCl} 6$ M dalam beaker glass $250 \mathrm{~mL}$. Selanjutnya dilakukan penyaringan dan larutan dengan cangkang telur yang terlarut diencerkan dalam labu volumetrik hingga 250 $\mathrm{mL}$. Sebanyak $10 \mathrm{~mL}$ aliquot dimasukkan ke dalam labu Erlenmeyer $250 \mathrm{~mL}$ dan ditambahkan larutan buffer $\mathrm{pH}$ 10. Setelah itu dilakukan titrasi dengan larutan EDTA 0,05 M dan menghabiskan 38,4 mL untuk mencapai titik akhir titrasi. Tentukan kadar kalsium yang ada di dalam cangkang telur sebagai $\%$ $\mathrm{b} / \mathrm{b} \mathrm{CaCO}$ !

3. Kalsium karbonat murni Sebanyak $50 \mathrm{mg}$ diasamkan dan dilarutkan dalam $100 \mathrm{~mL}$ larutan. Sampel kemudian diambil sebanyak 10,0 mL dan dititrasi dengan larutan EDTA. Sampel membutuhkan 15,0 mL larutan EDTA untuk titrasi. Hitunglah molaritas larutan EDTA tersebut! 


\section{BAB 6}

\section{TITRASI REDOKS}

\section{Sub-Capaian Pembelajaran Mata Kuliah}

1. Mahasiswa mampu menjelaskan dan memahami definisi reaksi oksidasi dan reduksi, dan menjelaskan dasar pengembangan metode redoks dalam titrasi.

2. Mahasiswa mampu mengolah data titrasi ke dalam kurva untuk menentukan titik akhir titrasi.

3. Mahasiswa mampu melakukan titrasi redoks dengan berbagai larutan standar (permanganat, bikromat, bromat, iodin) dan menyelesaikan perhitungan titrasi redoks.

\subsection{Perubahan Potensial Reduksi Selama Titrasi}

Pada titrasi redoks, karena didalamnya melibatkan reaksi reduksi-oksidasi, maka perubahan potensial yang menyertai dapat digunakan sebagai parameter reaksi. Oleh karena itu, perubahan potensial dapat dinyatakan melalui hubungan antara volume zat yang mengalami reduksi (oksidator) atau zat yang mengalami oksidasi (reduktor) yang ditambahkan dengan potensial sel yang terukur selama berlangsungnya titrasi. Sehingga perlu mempelajari kembali cara untuk mencari potensial sel pada saat titik ekuivalen terjadi. Besarnya potensial sel dapat ditentukan dengan menggunakan persamaan Nernst.

Persamaan Nernst untuk reaksi : a Oks $+\mathrm{n} \mathrm{e} \rightarrow \mathrm{b}$ Red dapat dinyatakan sebagai berikut : 


$$
\mathrm{E}=\mathrm{E}^{\mathrm{o}}-2,3026 \frac{\mathrm{RT}}{\mathrm{nF}} \log \frac{[\mathrm{Red}]^{\mathrm{b}}}{[\mathrm{oks}]^{\mathrm{a}}}
$$

Keterangan :

$$
\begin{array}{ll}
\mathrm{E} & =\text { Potensial sel reaksi } \\
\mathrm{E}^{\circ} & =\text { Potensial sel awal } \\
\mathrm{R} & =\text { Tetapan gas } \rightarrow 8,13 \mathrm{~J} \cdot \mathrm{mol}^{-1} \cdot \mathrm{K}^{-1} \\
\mathrm{~T} & =\text { Temperatur }(\mathrm{K}) \\
\mathrm{N} & =\text { Jumlah mol elektron yang terlibat dalam } \\
& \text { reaksi } \\
\mathrm{F} & =\text { Tetapan Faraday } \rightarrow 96.500 \mathrm{C} \cdot \mathrm{mol}^{-1} \\
\mathrm{Red} & =\text { Reduktor } \\
\text { Oks } & =\text { Oksidator }
\end{array}
$$

\subsection{Penentuan Titik Akhir Titrasi}

Titrasi redoks merupakan titrasi terhadap larutan analit berupa reduktor atau oksidator dengan titran berupa larutan dari zat standar oksidator atau reduktor. Prinsip yang digunakan dalam titrasi redoks adalah reaksi reduksi-oksidasi atau yang dikenal dengan reaksi redoks.

Dalam titrasi redoks, penentuan titik akhir titrasi diperlukan suatu indikator yang dapat memberikan perubahan warna pada saat titik akhir titrasi tercapai. Sehingga dapat dikatakan bahwa indikator redoks merupakan suatu senyawa atau zat yang dapat berubah warnanya karena terjadi adanya reaksi reduksi-oksidasi (redoks). Seperti halnya pada indikator yang digunakan dalam titrasi asambasa (asidi-alkalimetri), titrasi pembentukan kompleks (kompleksometri), maupun titrasi pengendapan (titrasi argentometri), maka pada titrasi redoks juga memerlukan indikator redoks untuk menunjukkan warna yang berbeda pada keadaan teroksidasi dan warna tereduksi. Berikut ini merupakan jenis indikator yang dapat digunakan dalam titrasi redoks, antara lain : 
a. Indikator Redoks Reversible

Indikator redoks reversible merupakan suatu indikator redoks yang tidak bergantung pada salah satu zat, tetapi tergantung pada perubahan potensial larutan selama titrasi. Oleh sebab itu, indikator ini digunakan secara luas dalam penentuan titik akhir titrasi redoks.disebut reversible karena indikator ini dapat dioksidasi dan direduksi secara bolak-balik. Perubahan warna antara indikator reversible memiliki hubungan dengan potensial elektrokimia yang setengah reaksinya dapat ditulis secara sebagai berikut :

$$
\underset{\text { Warna A }}{\operatorname{In}_{\text {Oks }}+\mathrm{ne}^{-} \leftrightarrow} \underset{\text { Warna B }}{\operatorname{In}_{\text {Red }}}
$$

Dengan keterangan, $\mathrm{In}_{\mathrm{Oks}}$ merupakan indikator dalam bentuk oksidator dan $\operatorname{In}_{\text {Red }}$ merupakan indikator dalam bentuk reduktor. Reaksi yang terjadi dapat ditulis berdasarkan persamaan Nernst sebagai berikut :

$$
\mathrm{E}=\mathrm{E}_{\frac{\mathrm{In}_{\mathrm{Kks}}}{\mathrm{In}_{\mathrm{Red}}}}^{\infty}-\frac{0.059}{\mathrm{n}} \log \frac{\left[\mathrm{In}_{\mathrm{Red}}\right]}{\left[\mathrm{In}_{0 \mathrm{ks}}\right]}
$$

Adanya perubahan warna indikator diasumsikan terjadi ketika perbandingan $\left[\operatorname{In}_{\mathrm{Oks}}\right] /\left[\mathrm{In}_{\text {Red }}\right]$ berubah dari 0,1 ke 10 . Dengan demikian, jika perbandingannya lebih kecil atau sama dengan 0,1 , maka hanya warna A yang teramati. Sebaliknya, jika perbandingannya adalah lebih besar ata sama dengan 10 , maka warna B yang akan teramati. Sehingga, daerah perubahan warna indikator ( $\Delta \mathrm{E}$ Indikator) adalah $\pm 2 \times 0,059 \mathrm{~V}= \pm 0,12$ V.

Berdasarkan Tabel 6.1 menunjukkan beberapa jenis indikator redoks reversible dengan warna-warna yang teramati 
pada keadaan tereduksi maupun teroksidasi yang disertai dengan potensial peralihannya. Potensial peralihan (transition potensial) merupakan potensial sel yang terukur ketika konsentrasi $\operatorname{In}_{\mathrm{Oks}}$ dan $\operatorname{In}_{\text {Red }}$ masing-masing sebesar $50 \%$.

Penggunaan indikator redoks reversible ini harus sesuai dengan reaksi redoks yang terjadi pada saat titrasi. Sehingga dapat dikatakan, bahwa tidak semua indikator redoks reversible dapat digunakan untuk semua jenis titrasi redoks. Syarat untuk pemilihan indikator yang cocok dapat ditentukan oleh kekuatan oksidasi titran dan analit atau potensial pada saat titik ekuivalen titrasi tersebut. Diperlukan usaha untuk mempertahankan $\mathrm{pH}$ larutan selama proses titrasi berlangsung karena potensial peralihan indikator sanga bergantung pada $\mathrm{pH}$ larutan.

Tabel 6.1 Indikator Redoks dan Potensial Transisinya

\begin{tabular}{|c|c|c|c|c|}
\hline Indikator & $\begin{array}{c}\text { Warna } \\
\text { Reduktor }\end{array}$ & $\begin{array}{c}\text { Warna } \\
\text { Oksidator }\end{array}$ & $\begin{array}{c}\text { Potensial } \\
\text { Transisi } \\
(\mathrm{V}) \\
\end{array}$ & Kondisi \\
\hline Metilen biru & $\begin{array}{l}\text { Tak } \\
\text { berwarna }\end{array}$ & Biru & 0,53 & $\begin{array}{l}1 \\
\text { asam }\end{array}$ \\
\hline Difenilamin & $\begin{array}{l}\text { Tak } \\
\text { berwarna }\end{array}$ & Ungu & 0,76 & $\begin{array}{l}1 \\
\mathrm{H}_{2} \mathrm{SO}_{4}\end{array}$ \\
\hline Difenilbenzidin & $\begin{array}{l}\text { Tak } \\
\text { berwarna }\end{array}$ & Ungu & 0,76 & $\begin{array}{l}1 \\
\mathrm{H}_{2} \mathrm{SO}_{4}\end{array}$ \\
\hline $\begin{array}{l}\text { Asam } \\
\text { difenilamin } \\
\text { sulfonate }\end{array}$ & $\begin{array}{l}\text { Tak } \\
\text { berwarna }\end{array}$ & $\begin{array}{l}\text { Merah- } \\
\text { Ungu }\end{array}$ & 0,85 & $\begin{array}{l}\text { Asam } \\
\text { encer }\end{array}$ \\
\hline Ferroin & Merah & Biru muda & 1,11 & $\begin{array}{l}1 \\
\mathrm{H}_{2} \mathrm{SO}_{4}\end{array}$ \\
\hline
\end{tabular}




\begin{tabular}{lllll}
\hline Nitroferroin & Merah & Biru muda & 1,25 & $\begin{array}{l}1 \\
\mathrm{H}_{2} \mathrm{SO}_{4}\end{array}$ \\
\hline
\end{tabular}

(Sumber : Day \& Underwood, 2001: 280)

b. Indikator Redoks Khusus

Indikator redoks khusus merupakan suatu indikator yang dapat bereaksi dengan salah satu komponen pereaksi dan tidak dipengaruhi oleh potensial redoks. Salah satu indikator redoks khusus adalah amilum pada titrasi redoks iodometrir/iodimetri. Amilum merupakan suatu indikator yang dapat membentuk kompleks berwarna biru tua dengan iodium. Berdasarkan penggunaannya, reaksi pembentukan yang terjadi antara kompleks amilum dengan iodium sebagai berikut :

$$
\mathrm{I}_{2}+\text { amilum } \rightarrow \text { Iod-amilum (biru) }
$$

Iod-amilum $+\mathrm{S}_{2} \mathrm{O}_{3}^{2-} \rightarrow$ Warna hilang (tak berwarna)

Dengan demikian, reaksi antara lod dengan amilum akan membentuk kompleks iod-amilum yang ditandai deangan warna biru tua. Pada waktu penambahan titran ion tiosulfat, maka kompleks iod-amilum menjadi pecah, sehingga ketika konsentrasiiod habis, maka warna biru tua tersebut akan hilang atau berubah menjadi bening (jernih). Pada saat inilah titrasi harus segera dihentikan.

Kurva Titrasi Redoks. Pada titrasi oksidimetri, konsentrasi suatu zat atau ion yang terlibat dalam suatu reaksi akan berubah secara kontinyu, sehingga potensial larutan (E) juga berubah. Kurva titrasi diperoleh dengan mengalurkan potensial terhadap perubahan titran yan ditambahkan, seperti kurva titrasi netralisasi. 
Kurva oksidimetri biasanya tidak tergantung pada pengenceran, namun dengan persamaan Nerst yang terdiri dari perbandingan konsentrasi bentuk teroksidasi dan tereduksi, sehingga tidak berubah dengan pengenceran. Keuntungan lainnya adalah pada titik belok kurva titrasi oksidimetri dapat dipelebar jika salah satu ion yang terbentuk akan berubah menjadi kompleks.

Kecepatan Reaksi Redoks. Reaksi redoks memiliki sifat spesifik yang menjadi kesulitan dalam analisis volumetri. Sifat tersebut merupakan reversibilitas yang harus dicegah dan banyak reaksi redoks yang berlangsung secara lambat. Seperti yang diketahui, reaksi yang lambat tidak cocok untuk digunakan titrasi, bukan hanya itu saja titrasinya akan menjadi sangat lambat, namun juga tidak dapat dijalankan dengan cukup akurat. Oleh karena itu, reaksi dalam analisis volumetri untuk reaksi yang lambat harus dipercepat. Reaksi yang lambat dapat dipercepat dengan berbagai metoda diantaranya adalah dengan meningkatkan suhu larutan dengan menggunakan pemanasan.

\subsection{Titrasi Permanganometri}

Titrasi permanganometri merupakan titrasi yang dilakukan berdasarkan reaksi oleh kalium permanganat $\left(\mathrm{KMnO}_{4}\right)$. Reaksi ini difokuskan pada reaksi oksidasi dan reduksi. Yang terjadi antara $\mathrm{KMnO}_{4}$ dengan suatu bahan tertentu. Pada reaksi permanganometri ini, ion $\mathrm{MnO}_{4}^{-}$bertindak sebagai oksidator kuat. Ion $\mathrm{MnO}_{4}^{-}$akan berubah menjadi ion $\mathrm{Mn}^{2+}$ dalam suasana asam.

Kalium permanganat $\left(\mathrm{KMnO}_{4}\right)$ merupakan oksidator yang mudah diperoleh, murah, dan tidak memerlukan indikator (autoindikator) untuk menunjukkan perubahan warna yang terjadi. 
Oleh karena itu, setetes larutan $\mathrm{KMnO}_{4}$ 0,1 N saja sudah memberikan warna merah muda yang jelas. Apabila titik ekuivalen belum tercapai, maka warna tersebut akan hilang ketika kembali dihomogenkan. Pada saat warna larutan analit berubah menjadi merah muda dan warna tersebut tidak berubah atau hilang (relatif permanen), maka proses titrasi sudah bisa dihentikan atau sudah mencapai titik akhir titrasi.

Kalium permanganat bukan merupakan larutan baku primer, maka larutan $\mathrm{KMnO}_{4}$ harus distandarisasi, antara lain dengan arsen(III) oksida $\left(\mathrm{As}_{2} \mathrm{O}_{3}\right)$ dan Natrium oksalat $\left(\mathrm{Na}_{2} \mathrm{C}_{2} \mathrm{O}_{4}\right)$. Permanganometri dapat digunakan untuk penentuan kadar besi, kalsium dan hidrogen peroksida. Pada penentuan besi, pada biji besi mula-mula dilarutkan dalam asam klorida, kemudian semua besi direduksi menjadi $\mathrm{Fe}^{2+}$, lalu dititrasi secara permanganometri. Sedangkan pada penetapan kalsium, mula-mula .kalsium diendapkan sebagai kalsium oksalat kemudian endapan dilarutkan dan oksalatnya lalu dititrasi dengan permanganat.

Permanganat bereaksi secara beraneka, karena mangan dapat memiliki keadaan oksidasi $+2,+3,+4,+6$, dan +7 . Larutan permanganat berwarna ungu, jika titrasi dilakukan untuk larutan yang tidak berwarna, indikator tidak diperlukan. Namun jika larutan permanganat yang digunakan dalam keadaan encer, maka penambahan indikator dapat dilakukan. Beberapa indikator yang dapat dipergunakan seperti feroin, asam $\mathrm{N}$-fenil antranilat.

Reaksi antara larutan kalium permanganat $\left(\mathrm{KMnO}_{4}\right)$ dengan suatu bahan reduktor dapat menghasilkan senyawa mangan $\left(\mathrm{Mn}^{2+}\right)$ dengan beberapa jenis bilangan oksidasi. Sehingga jumlah bilangan 
oksidasi mangan $\left(\mathrm{Mn}^{2+}\right)$ yang dihasilkan tergantung pada $\mathrm{pH}$ larutan seperti yang terjadi pada reaksi reduksi berikut ini :
a. $\mathrm{MnO}_{4}^{-}+8 \mathrm{H}^{+}+5 \mathrm{e} \leftrightarrow \mathrm{Mn}^{2+}+4 \mathrm{H}_{2} \mathrm{O}$
$\mathrm{E}^{\circ}=1,51 \mathrm{~V}$
(suasana asam kuat)
b. $\mathrm{MnO}_{4}^{-}+8 \mathrm{H}^{+}+4 \mathrm{e} \leftrightarrow \mathrm{Mn}^{3+}+4 \mathrm{H}_{2} \mathrm{O} \quad \mathrm{E}^{\circ}=1,50 \mathrm{~V}$ (suasana asam)
c. $\mathrm{MnO}_{4}^{-}+4 \mathrm{H}^{+}+3 \mathrm{e} \leftrightarrow \mathrm{MnO}_{2}+2 \mathrm{H}_{2} \mathrm{O} \quad \mathrm{E}^{\circ}=1,70 \mathrm{~V}$ $(\mathrm{pH} 2-12)$
d. $\mathrm{MnO}_{4}^{-}+\mathrm{e} \leftrightarrow \mathrm{MnO}_{4}^{2-} \quad \mathrm{E}^{\circ}=0,56 \mathrm{~V}$ (suasana basa kuat)
Pada reaksi (a) dan (d) terlihat relatif kurang stabil dibandingkan dengan reaksi (b) dan (c). Oleh sebab itu, larutan standar $\mathrm{KMnO}_{4}$ akan berubah menjadi ion $\mathrm{Mn}^{2+}$ pada suasana asam, sedangkan pada suasana basa akan berubah menjadi mangan dioksida $\left(\mathrm{MnO}_{2}\right)$.

Larutan kalium permanganat $\left(\mathrm{KMnO}_{4}\right)$ merupakan larutan standar sekunder karena larutan tersebut mudah terurai jika terkena cahaya, temperatur tinggi, dan asam atau basa. Sehingga larutan kalium permanganat $\left(\mathrm{KMnO}_{4}\right)$ harus distandarisasi terlebih dahulu sebelum digunakan untuk analisis kimia.

\subsection{Titrasi Iodo dan Iodimetri}

Pada titrasi lodo dan lodimetri, iodin $\left(\mathrm{I}_{2}\right)$ tidak mudah larut dalam air, tetapi mudah larut dalam larutan yang mengandung ion iodida sehingga hasilnya membentuk triiodida $\left(\mathrm{I}_{3}^{-}\right)$.

$$
\mathrm{I}_{2}+\mathrm{I}^{-} \rightarrow \mathrm{I}_{3}^{-}
$$


Dengan penambahan kalium iodida dapat meningkatkan kelarutannya. Karena penambahan kalium iodida dapat mengurangi sifat iodin yang mudah menguap. Iodin (dalam bentuk triiodida, $\mathrm{I}_{3}^{-}$) merupakan oksidator yang lebih lemah daripada kalium permanganat dan kalium dikromat. Reaksi dari potensial reduksi standar iodin sebesar 0,54 V sebagai berikut :

$$
\mathrm{I}_{3}^{-}+2 \mathrm{e}^{-} 2_{2}^{-} \quad \mathrm{E}^{\circ}=0,54 \mathrm{~V}
$$

Bentuk triiodida merupakan bentuk iodin sebenarnta yang digunakan untuk mempermudah pembahasan dalam buku ini yang akan ditulis dalam bentuk $\mathrm{I}_{2}$. Secara umum, analisis titrimetri yang melibatkan iodin dibedakan menjadi 2 (dua) macam, yaitu titrasi iodometri (titrasi tak langsung) dan titrasi iodimetri (titrasi langsung).

a. Titrasi Iodometri (titrasi tak langsung)

Dinamakan titrasi lodometri atau titrasi tak langsung karena merupakan titrasi terhadap larutan analit dengan larutan natrium tiosulfat sebagai larutan standar (titran) dengan menambahkan amilum (kanji) sebagai indikatornya serta digunakan untuk menetapkan senyawa- senyawa yang mempunyai potensial oksidasi lebih besar daripada sistem iodium-iodida atau senyawa-senyawa yang bersifat oksidator seperti $\mathrm{CuSO}_{4} \times 5 \mathrm{H}_{2} \mathrm{O}$. Iodometri terjadi pada zat yang bersifat oksidator seperti besi (III), tembaga (II), dimana zat ini akan mengoksidasi iodida yang ditambahkan membentuk iodin.

Pada titrasi iodometri adanya banyak oksidator kuat yang dianalisis dengan menambahkan sejumlah kalium iodida 
berlebih dan menitrasi iodin yang dibebaskan dengan larutan natrium tiosulfat. Maka reaksi yang terjadi sebagai berikut :

$$
\begin{aligned}
& \text { Oksidator }+2 \mathrm{I}^{-} \rightarrow \mathrm{I}_{2}+\text { Reduktor } \\
& \mathrm{I}_{2}+2 \mathrm{Na}_{2} \mathrm{~S}_{2} \mathrm{O}_{3} \rightarrow 2 \mathrm{I}^{-}+\mathrm{Na}_{2} \mathrm{~S}_{4} \mathrm{O}_{6}
\end{aligned}
$$

Titik akhir titrasi ditentukan menggunakan indikator amilum yang ditambahkan sesaat sebelum titik akhir titrasi tercapai. Titik akhir titrasi yang tercapai ditunjukkan dengan hilangnya warna biru gelap dari kompleks iodin-amilum yang dapat bertindak sebagai suatu tes atau uji yang amat sensitif untuk iodin.

Amilum merupakan indikator redoks khusus yang digunakan sebagai petunjuk apabila telah terjadi ekuivalen pada titrasi iodometri. Hal ini disebabkan karena warna biru gelap yang muncul akibat dari kompleks iodin-amilum merupakan warna yang spesifik untuk titrasi iodometri ini. Mekanismenya belum tentu diketahui dengan pasti namun, ada asumsi bahwa molekul iodin tertahan di permukaan $\beta$-amilosa. Larutan amilum mudah terdekomposisi oleh bakteri, sehingga biasanya ditambahkan asam borat sebagai pengawetnya. Berikut ini adalat tabel 6.2 sebagai penentuan analit melalui titrasi iodometri :

\section{Tabel 6.2 Penentuan Analit melalui Titrasi Iodometri}

\begin{tabular}{|l|l|}
\hline \multicolumn{1}{|c|}{ Analit } & \multicolumn{1}{c|}{ Reaksi } \\
\hline Arsen $(\mathrm{V})$ & $\mathrm{H}_{3} \mathrm{AsO}_{4}+2 \mathrm{H}^{+}+2 \mathrm{I}^{-} \rightarrow \mathrm{HAsO}_{2}+\mathrm{I}_{2}+2 \mathrm{H}_{2} \mathrm{O}$ \\
\hline Bromin & $\mathrm{Br}_{2}+2 \mathrm{I}^{-} \rightarrow 2 \mathrm{Br}^{-}+\mathrm{I}_{2}$ \\
\hline Bromat & $\mathrm{BrO}_{3}^{-}+6 \mathrm{H}^{+}+6 \mathrm{I}^{-} \rightarrow 3 \mathrm{I}_{2}+\mathrm{Br}^{-}+3 \mathrm{H}_{2} \mathrm{O}$ \\
\hline Klorin & $\mathrm{Cl}_{2}+2 \mathrm{I}^{-} \rightarrow 2 \mathrm{Cl}^{-}+\mathrm{I}_{2}$ \\
\hline
\end{tabular}




\begin{tabular}{|l|l|}
\hline Klorat & $\mathrm{ClO}_{3}^{-}+6 \mathrm{H}^{+}+6 \mathrm{I}^{-} \rightarrow \mathrm{Cl}^{-}+\mathrm{I}_{2}+3 \mathrm{H}_{2} \mathrm{O}$ \\
\hline Tembaga (II) & $2 \mathrm{Cu}^{2+}+4 \mathrm{I}^{-} \rightarrow 2 \mathrm{CuI}(\mathrm{s})+\mathrm{I}_{2}$ \\
\hline Dikromat & $\mathrm{Cr}_{2} \mathrm{O}_{7}^{2-}+14 \mathrm{H}^{+}+6 \mathrm{I}^{-} \rightarrow 2 \mathrm{Cr}^{3+}+3 \mathrm{I}_{2}+7 \mathrm{H}_{2} \mathrm{O}$ \\
\hline $\begin{array}{l}\text { Hidrogen } \\
\text { peroksida }\end{array}$ & $\mathrm{H}_{2} \mathrm{O}_{2}+2 \mathrm{H}^{+}+2 \mathrm{I}^{-} \rightarrow \mathrm{I}_{2}+2 \mathrm{H}_{2} \mathrm{O}$ \\
\hline Iodat & $\mathrm{IO}_{3}^{-}+6 \mathrm{H}^{+}+5 \mathrm{I}^{-} \rightarrow 3 \mathrm{I}_{2}+3 \mathrm{H}_{2} \mathrm{O}$ \\
\hline Nitrit & $2 \mathrm{HNO}_{2}+2 \mathrm{H}^{+}+2 \mathrm{I}^{-} \rightarrow 2 \mathrm{NO}+\mathrm{I}_{2}+2 \mathrm{H}_{2} \mathrm{O}$ \\
\hline Oksigen & $\mathrm{O}_{2}+4 \mathrm{Mn}(\mathrm{OH})_{2}+2 \mathrm{H}_{2} \mathrm{O} \rightarrow 4 \mathrm{Mn}\left(\mathrm{OH}_{3}\right.$ \\
& $2 \mathrm{Mn}(\mathrm{OH})_{3}+2 \mathrm{I}^{-}+6 \mathrm{H}^{+} \rightarrow 2 \mathrm{Mn}^{2+}+\mathrm{I}_{2}+$ \\
& $6 \mathrm{H} \mathrm{O}_{2}$ \\
\hline Ozon & $\mathrm{O}_{3}+2 \mathrm{I}^{-}+2 \mathrm{H}^{+} \rightarrow \mathrm{O}_{2}+\mathrm{I}_{2}+\mathrm{H}_{2} \mathrm{O}$ \\
\hline Periodat & $\mathrm{IO}_{4}^{-}+7 \mathrm{I}^{-}+8 \mathrm{H}^{+} \rightarrow 4 \mathrm{I}_{2}+4 \mathrm{H}_{2} \mathrm{O}$ \\
\hline Permanganat & $2 \mathrm{MnO}_{4}^{-}+10 \mathrm{I}^{-}+16 \mathrm{H}^{+} \rightarrow 2 \mathrm{Mn}^{2+}+5 \mathrm{I}_{2}+$ \\
& $8 \mathrm{H}_{2} \mathrm{O}$ \\
\hline
\end{tabular}

\section{(Sumber : Christian, 2004: 428)}

b. Titrasi Iodimetri (titrasi langsung)

lodimetri merupakan titrasi secara tak langsung, artinya titrasi terhadap larutan analit dengan larutan iodin sebagai larutan standar (titran) dengan menggunakan indikator amilum. Ada beberapa senyawa yang dapat dititrasi dengan larutan iodin adalah tiosulfat $\left(\mathrm{S}_{2} \mathrm{O}_{3}^{2-}\right)$, arsen (III), antimony (III), sulfida $\left(\mathrm{S}^{2-}\right)$, sulfit $\left(\mathrm{SO}_{3}^{2-}\right)$, dan ferosianida $\left[\mathrm{Fe}(\mathrm{CN})_{6}^{4-}\right]$. Larutan iodin ini merupakan larutan standar sekunder, sehingga sebelum digunakan untuk titrasi harus distandarisasi terlebih dahulu dengan larutan standar primer. Arsen trioksida $\left(\mathrm{As}_{2} \mathrm{O}_{3}\right)$ merupakan larutan standar primer yang dapat digunakan untuk strandarisasi larutan iodin. Senyawa $\mathrm{As}_{2} \mathrm{O}_{3}$ dilarutkan dalam natrium hidroksida dan kemudian dinetralkan dengan penambahan asam. Reaksi yang terjadi adalah :

$$
\mathrm{As}_{2} \mathrm{O}_{3}+2 \mathrm{NaOH} \rightarrow 2 \mathrm{NaAsO}_{2}+\mathrm{H}_{2} \mathrm{O}
$$




\section{$\mathrm{NaAsO}_{2}+\mathrm{HNO}_{3} \rightarrow \mathrm{HasO}_{2}+\mathrm{NaNO}_{3 \mathrm{r}}$}

Selanjutnya, asam arsenit yang dihasilkan dititrasi dengan larutan iodin. Asam arsenit teroksidasi menjadi asam arsenat, sedangkan larutan iodin berubah menjadi iodida. Reaksi yang terjadi adalah :

$$
\mathrm{HAsO}_{2}+\mathrm{I}_{2}+2 \mathrm{H}_{2} \mathrm{O} \rightarrow \mathrm{H}_{3} \mathrm{AsO}_{4}+3 \mathrm{H}^{+}+2 \mathrm{I}^{-}
$$

Titrasi iodimetri dilakukan dalam keadaan netral atau dalam suasana asam lemah sampai basa lemah. Larutan iodin dapat mengalami reaksi disproporsionasi jika berada pada $\mathrm{pH}$ tinggi (basa kuat). Reaksi yang terjadi adalah :

$$
\mathrm{I}_{2}+2 \mathrm{OH}^{-} \rightarrow \mathrm{IO}^{-}+\mathrm{I}^{-}+\mathrm{H}_{2} \mathrm{O}
$$

Sedangkan jika titrasi berlangsung pada $\mathrm{pH}$ rendah, makan indikator amilum akan terhidrolisis. Selain itu, ion iodida $\left(\mathrm{I}^{-}\right)$yang dihasilkan pada suasana asam juga dapat teroksidasi menjadi $\mathrm{I}_{2}$ dengan adanya $\mathrm{O}_{2}$ yang berasal dari udara bebas. Dengan demikian, dalam suasana asam akan terjadi oksidasi ion iodida menjadi iodin. Reaksi yang terjadi adalah :

$$
4 \mathrm{I}^{-}+\mathrm{O}_{2}+4 \mathrm{H}^{+} \rightarrow 2 \mathrm{I}_{2}+2 \mathrm{H}_{2} \mathrm{O}
$$

Beberapa reaksi penentu analit dengan menggunakan titrasi iodimetri dapat ditulis dalam reaksi sebagai berikut :

- $\mathrm{H}_{2} \mathrm{~S}+\mathrm{I}_{2} \rightarrow \mathrm{S}+2 \mathrm{I}^{-}+2 \mathrm{H}^{+}$

- $\mathrm{SO}_{3}^{2-}+\mathrm{I}_{2}+\mathrm{H}_{2} \mathrm{O} \rightarrow \mathrm{SO}_{4}^{2-}+2 \mathrm{I}^{-}+2 \mathrm{H}^{+}$

- $\mathrm{Sn}^{2+}+\mathrm{I}_{2} \rightarrow \mathrm{Sn}^{4+}+2 \mathrm{I}^{-}$

- $\mathrm{HAsO}_{2}+\mathrm{I}_{2}+2 \mathrm{H}_{2} \mathrm{O} \rightarrow \mathrm{H}_{3} \mathrm{AsO}_{4}+3 \mathrm{H}^{+}+2 \mathrm{I}^{-}$

- $2 \mathrm{~S}_{2} \mathrm{O}_{3}^{2-}+\mathrm{I}_{2} \rightarrow 2 \mathrm{I}^{-}+\mathrm{S}_{4} \mathrm{O}_{6}^{2-}$

- $\mathrm{HSBOC}_{4} \mathrm{H}_{6} \mathrm{O}_{6}+\mathrm{I}_{2}+\mathrm{H}_{2} \mathrm{O} \rightarrow \mathrm{HSBO}_{2} \mathrm{C}_{4} \mathrm{H}_{6} \mathrm{O}_{6}+2 \mathrm{I}^{-}+$ $2 \mathrm{H}^{+}$

- $2 \mathrm{Fe}(\mathrm{CN})_{6}^{4-}+\mathrm{I}_{2}+\mathrm{H}_{2} \mathrm{O} \rightarrow 2 \mathrm{Fe}(\mathrm{CN})_{6}^{3-}+2 \mathrm{I}^{-}$ 


\subsection{Titrasi Bikromatometri}

Titrasi bikromatometri atau juga yang biasanya disebut dengan titrasi dikromatometri merupakan titrasi redoks yang menggunakan larutan dikromat $\left(\mathrm{Cr}_{2} \mathrm{O}_{7}^{2-}\right)$ sebagai larutan standar. Senyawa kalium dikromat merupakan oksidator yangkuat namun, lebih lemah daripada kalium permanganat $\left(\mathrm{E}^{\prime \prime}=\mathrm{Cr}_{2} \mathrm{O}_{7}^{2-} \leq \mathrm{E}^{\prime \prime}=\right.$ $\mathrm{MnO}_{4}^{-}$). Sehingga reaksi yang terbentuk antara reduksi dengan potensial reduksi dari kalium dikromat adalah :

$$
\mathrm{Cr}_{2} \mathrm{O}_{7}^{2-}+14 \mathrm{H}^{+}+6 \mathrm{e} \leftrightarrow 2 \mathrm{Cr}^{3+}+7 \mathrm{H}_{2} \mathrm{O} \quad \mathrm{E}^{\circ}=1,33 \mathrm{~V}
$$

Selain harganya yang terjangkau, larutan standar kalium dikromat juga memiliki keuntungan lain yaitu merupakan larutan standar primer dan sangat stabil. Penggunaan utamanya adalah untuk titrasi besi (II) dalam larutan asam klorida $(\mathrm{HCl}<2 \mathrm{M})$. Asam difenilaminsulfonat $\left(E^{\circ}=0,85 \mathrm{~V}\right)$ atau natrium difenilbenzidin $\left(E^{\circ}=\right.$ $0,87 \mathrm{~V})$ merupakan indikator yang cocok untuk digunakan dengan larutan standar kalium dikromat. Reaksi yang terjadi antara ion besi (II) dengan ion kromat adalah :

$$
\mathrm{Cr}_{2} \mathrm{O}_{7}^{2-}+6 \mathrm{Fe}^{2+}+14 \mathrm{H}^{+} \leftrightarrow 2 \mathrm{Cr}^{3+}+6 \mathrm{Fe}^{3+}+7 \mathrm{H}_{2} \mathrm{O}
$$

Pada reaksi tersebut, reduksi terjadi pada ion kalium dikromat menjadi ion krom (III), sedangkan oksidasi dari ion besi (II) menjadi ion besi (III). Penggunaan kalium dikromat dapat juga untuk menentukan zat-zat oksidator yang lain melalui titrasi balik dengan cara menambahkan sejumlah tertentu besi (II) berlebih kemudian kelebihan besi (II) tersebut dititrasi dengan kalium bikromatometri antara lain nitrat $\left(\mathrm{NO}_{3}^{-}\right)$, klorat $\left(\mathrm{ClO}_{3}^{-}\right)$, dan hidrogen peroksida $\left(\mathrm{H}_{2} \mathrm{O}_{2}\right)$. 


\subsection{Titrasi Bromatometri}

Titrasi bromatometri merupakan titrasi redoks yang menggunakan ion kromat sebagai larutan standar. Kalium bromat merupakan oksidator yang kuat dan memiliki potensial reduksi standar sebesar 1,22 Volt. Reaksi reduksi yang terjadi adalah :

$$
\mathrm{BrO}_{3}^{-}+6 \mathrm{H}^{+}+6 \mathrm{e} \leftrightarrow \mathrm{Br}^{-}+3 \mathrm{H}_{2} \mathrm{O} \quad \mathrm{E}^{\circ}=1,44 \mathrm{~V}
$$

Titrasi bromatometri dapat digunakan untuk titrasi langsung terhadap beberapa reduktor seperti As(III), Fe(II), atau sulfida organik. Contoh reaksi yang terbentuk antara As(III) dengan ion bromat pada titrasi langsung adalah :

$$
\mathrm{BrO}_{3}^{-}+3 \mathrm{HAsO}_{2} \rightarrow \mathrm{Br}^{-}+3 \mathrm{HAsO}_{3}
$$

Reaksi tersebut biasanya berlangsung dalam larutan $\mathrm{HCl} 1$ M. Apabila $\mathrm{HAsO}_{2}$ telah habis bereaksi dengan ion bromat, maka penambahan ion bromat akan bereaksi dengan ion bromida yang akan menghasilkan brom. Dengan demikian, reaksiyang terjadi pada titik akhir titrasi ditandai oleh munculnya brom sebagai berikut :

$$
\mathrm{BrO}_{3}^{-}+3 \mathrm{Br}^{-}+6 \mathrm{H}^{+} \rightarrow 3 \mathrm{Br}_{2}+3 \mathrm{H}_{2} \mathrm{O}
$$

Kalium bromat juga dapat digunakan untuk menghasilkan sejumlah brom $\left(\mathrm{Br}_{2}\right)$. Brom yang dihasilkan tersebut dapat digunakan untuk brominasi senyawa organik seperti 8hidroksikuinolin (oksin). Reaksi yang terjadi antara brom dengan oksi disebut reaksi substitusi. Sehingga reaksi yang terjadi adalah :

$$
\mathrm{C}_{9} \mathrm{H}_{7} \mathrm{ON}+2 \mathrm{Br}_{2} \rightarrow \mathrm{C}_{9} \mathrm{H}_{5} \mathrm{ONBr}_{2}+2 \mathrm{HBr}
$$

Senyawa oksin dapat bereaksi dengan sejumlah logam. Aluminium merupakan salah satu logam yang dapat bereaksi dengan oksin. Dengan demikian, analisis aluminium dalam larutan sampel dapat dilakukan dengan mereaksikan larutan sampel dengan larutan oksin. Endapan yang terbentuk antara ion aluminium dengan oksin berwarna kuning. Kemudian, endapan yang dihasilkan 
tersebut selanjutnya disaring, dicuci, dan dilarutkan dalam asam klorida. Larutan yang terjadi selanjutnya ditambahkan larutan standar $\mathrm{KBr}-\mathrm{KBrO}_{3}$. Larutan standar tersebut menghasilkan $\mathrm{Br}_{2}$ yang selanjutnya akan membrominasi larutan sampel. Sehingga reaksi-reaksi yang terjadi pada analisis aluminium dengan oksin sebagai berikut :

$$
\begin{array}{cc}
\mathrm{Al}^{3+}+3 \mathrm{HQ} \rightarrow \mathrm{AlQ}_{3}(\mathrm{~s})+3 \mathrm{H}^{+} & \text {(Pengendapan) } \\
\mathrm{AlQ}_{3}(\mathrm{~s})+3 \mathrm{H}^{+} \rightarrow \mathrm{Al}^{3+}+3 \mathrm{HQ} & \text { (Pelarutan kembali) } \\
3 \mathrm{HQ}+6 \mathrm{Br}_{2} \rightarrow 3 \mathrm{HQBr} & +6 \mathrm{HBr} \quad \text { (Brominasi) }
\end{array}
$$

HQ merupakan singkatan dari 8-hidroksikuinolin (oksin).

Selain mengalami reaksi substitusi, brom juga dapat mengalami reaksi adisi apabila direaksikan deangan etilen. Sehingga reaksi yang terjadi antara brom dengan etilen menghasilkan divromida etana yang ditulis secara matematis sebagai berikut :

$$
\mathrm{H}_{2} \mathrm{C}=\mathrm{CH}_{2}+\mathrm{Br}_{2} \rightarrow \mathrm{H}_{2} \mathrm{CBr}-\mathrm{CBrH}_{2}
$$

Setelah terjadi reaksi brominasi secara sempurna, pada kelebihan brom selanjutnya ditambahkan ion iodida dan menghasilkan iod. lod yang dihasilkan tersebut kemudian dititrasi dengan ion tiosulfat.

\subsection{Rangkuman}

$>$ Besarnya potensial sel dapat ditentukan dengan menggunakan persamaan Nernst.

$>$ Prinsip yang digunakan dalam titrasi redoks adalah reaksi reduksi-oksidasi atau yang dikenal dengan reaksi redoks.

> Indikator redoks merupakan suatu senyawa atau zat yang dapat berubah warnanya karena terjadi adanya reaksi reduksi-oksidasi (redoks). 
> Titrasi permanganometri merupakan titrasi yang dilakukan berdasarkan reaksi oleh kalium permanganat $\left(\mathrm{KMnO}_{4}\right)$.

> Titrasi Iodometri atau titrasi tak langsung karena merupakan titrasi terhadap larutan analit dengan larutan natrium tiosulfat sebagai larutan standar (titran) dengan menambahkan amilum (kanji) sebagai indikatornya serta digunakan untuk menetapkan senyawa-senyawa yang mempunyai potensial oksidasi lebih besar daripada sistem iodium-iodida atau senyawa-senyawa yang bersifat oksidator seperti $\mathrm{CuSO}_{4} \cdot 5 \mathrm{H}_{2} \mathrm{O}$.

$>$ Titrasi Iodimetri merupakan titrasi secara tak langsung, artinya titrasi terhadap larutan analit dengan larutan iodin sebagai larutan standar (titran) dengan menggunakan indikator amilum.

$>$ Titrasi bikromatometri atau juga yang biasanya disebut dengan titrasi dikromatometri merupakan titrasi redoks yang menggunakan larutan dikromat $\left(\mathrm{Cr}_{2} \mathrm{O}_{7}^{2-}\right)$ sebagai larutan standar.

> Titrasi bromatometri merupakan titrasi redoks yang menggunakan ion kromat sebagai larutan standar.

\subsection{Latihan Soal}

Kerjakanlah soal di bawah ini sebagai sarana pemahaman anda terhadap materi Titrasi Redoks!

1. Dilakukan penetapan kadar ferro sulfat dengan metode titrasi permanganometri. Dari hasil titrasi diperlukan 12 $\mathrm{mL}$ larutan kalium permanganat $0,01 \mathrm{~N}$ untuk mencapai titik akhir titrasi. Tentukan massa ferro sulfat yang habis dalam reaksi, jika diketahui Mr ferro sulfat adalah 
278. (1 mL kalium permaganat $0,1 \mathrm{~N}$ setara dengan $27,80 \mathrm{mg}$ ferro sulfat).

2. Kadar vitamin $\mathrm{C}$ ditentukan dengan metode iodimetri dan diketahui bahwa 0,01 molar sampel bereaksi. Jika jumlah vitamin $\mathrm{C}$ yang digunakan adalah 142,56 gram dan $\mathrm{Mr}$ vitamin C adalah 105,17. Berapakah volume vitamin $\mathrm{C}$ yang digunakan untuk penetapan kadar?

3. Seorang mahasiswa akan melakukn praktikum titrasi iodometri. Mahasiswa tersebut memerlukan larutan $\mathrm{Na}_{2} \mathrm{~S}_{2} \mathrm{O}_{3} 0,01 \mathrm{~N}$. Jika volume larutan yang akan dibuat yaitu sebesar $1000 \mathrm{~mL}$. Maka hitunglah berapa gram $\mathrm{Na}_{2} \mathrm{~S}_{2} \mathrm{O}_{3}$ yang harus ditimbang? 
4.

\section{BAB 7}

\section{ANALISIS GRAVIMETRI}

\section{Sub-Capaian Pembelajaran Mata Kuliah}

3. Mahasiswa mampu menjelaskan dan memahami konsep dasar analisis gravimetri.

4. Mahasiswa mampu melakukan analisis dengan benar sesuai prosedur.

\subsection{Pendahuluan}

Analisis gravitrimetri atau analisis kuantitatif berdasarkan bobot, yaitu dimana suatu proses isolasi serta penimbangan suatu unsur atau senyawa tertentu dari unsur tersebut dalam bentuk yang semurni mungkin. Bagian terbesar dari penentuan secara analisis gravimetri meliputi transformasi unsur atau radikal senyawa murni stabil yang dapat segera diubah menjadi bentuk yang dapat di timbang dengan teliti. Lalu, bobot unsur atau radikal senyawa itu dengan mudah dapat dihitung dari pengetahuan tentang rumus senyawaannya serta bobot atom unsur-unsur penyusunannya (konstituennya).

Gravimetri adalah pemeriksaan jumlah zat dengan cara penimbangan hasil reaksi pengendapan. Gravimetri merupakan pemeriksaan jumlah zat yang paling tua dan paling sederhana dibandingkan dengan cara pemeriksaan kimia lainnya. Kesederhanaan itu kelihatan karena dalam gravimetri jumlah zat 
ditentukan dengan cara menimbang langsung massa zat yang dipisahkan dari zat-zat lain.

Pada pemisahan unsur atau senyawaan yang mengandungnya dapat dicapai dengan beberapa metode, antara lain : (a) pengendapan, (b) metode penguapan atau pembebasan (gas), (c) metode elektrolisis, dan (d) metode ekstraksi dan kromatografi. Hanya (a), (b), dan (c) yang akan dibahas pada bab ini.

Tahap pengukuran dalam metode gravimetri adalah penimbangan. Analitnya secara fisik dipisahkan dari semua komponen lain dari sampel itu maupun dari pelarutnya. Pengendapan merupakan teknik yang paling meluas penggunaannya untuk memisahkan analit dari penganggupengganggunya. Analisa gravimetri merupakan suatu cara analisa kimia kuantitatif yang didasarkan pada prinsip penimbangan berat yang di dapat dari proses pemisahan analit dari zat-zat lain dengan metode pengendapan. Zat yang telah di endapkan ini disaring dan dikeringkan serta ditimbang dan diusahakan endapan itu harus semurni mungkin. Untuk memisahkan endapan tersebut maka sangat dibutuhkan pengetahuan dan teknik yang cukup dan yang wajib dimiliki seorang enginer.

\subsection{Metode Gravimetri}

Metode gravimetri merupakan suatu metode yang digunakan dalam analisis gravimetri yang digunakan untuk menentukan kuantitas analit secara konvensional. Pada dasarnya, metode gravimetri dapat dilakukan dengan cara sebagai berikut :

a. Gravimetri dengan metode pengendapan

Pada metode ini, pereaksi tertentu yanda dapat digunakan untuk mengendapkan zat yang dianalisis. Syarat 
endapan yang dihasilkan harus berbentuk hablur kasar atau berupa kristal kasar agar mudah untuk dipisahkan dengan penyaringan. Contoh : Kalsium oksalat merupakan kalsium yang ditetapkan secara gravimetri dengan metode cara pengendapan sehingga terbentk endapan yang selanjutnya akan dikeringkan dan dipanggang. Endapan kalsium oksalat tersebut akan berubah menjadi kalsium oksida dengan melepaskan gas karbon dioksida dan karbon monoksida. Reaksi yang terjadi adalah :

$$
\begin{gathered}
\mathrm{Ca}^{2+}(\mathrm{aq})+\mathrm{C}_{2} \mathrm{O}_{4}^{2-}(\mathrm{aq}) \rightarrow \mathrm{CaC}_{2} \mathrm{O}_{4}(\mathrm{~s}) \\
\mathrm{CaC}_{2} \mathrm{O}_{4}(\mathrm{~s})+\mathrm{CaO}(\mathrm{s}) \rightarrow \mathrm{CO}_{2}(\mathrm{~g})+\mathrm{CO}(\mathrm{g})
\end{gathered}
$$

b. Gravimetri dengan cara penguapan atau pembebasan (gas)

Pada metode ini, analit akan diuapkan kemudian untuk zat yang tidak menguap akan ditimbang. Dengan demikian, pada massa bagian yang hilang/menguap dapat ditentukan kuantitatifnya. Contoh : pada penentuan kadar air yang terdapat dalam sampel organik dan penentuan air kristal (hidrat) yang terikat dalam suatu senyawa.

c. Gravimetri dengan cara elektrolisis

Pada metode ini, larutan yang mengandung analit diletakkan dalam sel elektrolisis. Proses elektrolisis berlangsung dalam waktu tertentu. Selama proses tersebut, logam yang telah mengendap di katode dapat ditentukan beratnya. Contoh: pada penentuan tembaga $(\mathrm{Cu})$ yang terdapat dalam larutan sampel dielektrolisis selama waktu tertentu dengan menggunakan katode platina (Pt) dalam kondisi asam. Sehingga, reaksi yang terjadi selama proses elektrolisis adalah :

$$
\text { Katode: } \begin{aligned}
\mathrm{Cu}^{2+}(\mathrm{aq})+2 \mathrm{e}^{-} \rightarrow \mathrm{Cu}(\mathrm{s}) \\
2 \mathrm{H}^{+}(\mathrm{aq})+2 \mathrm{e}^{-} \rightarrow \mathrm{H}_{2}(\mathrm{~g})
\end{aligned}
$$




\section{Anode : $2 \mathrm{H}_{2} \mathrm{O}(\mathrm{i}) \rightarrow 4 \mathrm{H}^{+}(\mathrm{aq})+\mathrm{O}_{2}(\mathrm{~g})+4 \mathrm{e}^{-}$}

Pada proses tersebut, pada katode ion $\mathrm{Cu}^{2+}$ yang terdapat dalam larutan sampel telah mengalami reduksi sehingga menghasilkan endapan $\mathrm{Cu}$, sedangkan pada anade terjadi reaksi oksidasi air yang menghasilkan ion $\mathrm{H}^{+}$dan $\mathrm{O}_{2}$. Massa endapan $\mathrm{Cu}$ yang dihasikan di katode dapat digunakan untuk perhitungan menentuakan selisih antara massa elektroda sesudah elektrolisis dengan sebelum elektrolisis.

\subsection{Kemurnian}

Proses pengendapan dalam analisis gravimetri, partikelpartikel hasil pengendapan ditentukan oleh proses nukleasi dan pembentukan nukleus. Sehingga, dalam analisa gravimetri harus selalu diupayakan agara terdapat endapan yang murni dan partikelpartikelnya cukup besar sehingga mudah disaring dan dicuci.

a. Kemurnian Endapan

Endapan yang telah terjadi akan mangandung zat-zat pengatur dan itu akan bergabung pada sifat endapan dan pada kondisi-kondisi dimana endapan itu terjadi yang akan menyebabkan terjadinya kontaminasi yang disebabkan karena adsorpsi pada permukaan kristal yang berbeda dengan larutan, dan jika luas permukaannya besar maka jumlah zat yang teradsorpsi bertambah banyak. Kopresipitasi juga dapat menyebabkan terjadinya oklusi, yaitu suatu zat-zat asing yang masuk kedalam kristal pada proses pertumbuhan kristal.

Bila pada proses pertumbuhan kristal berjalan secara lambat, maka zat pengatur akan larut dan kristal yang terjadi lebih besar dan murni. Kopresipitasi tidak dapat dihilangkan dengan pencucian dan untuk cara mengatasinya bisa dengan 
melarutkan kembali endapan tersebut dan kemudian diendapkan kembali juga. Karena konsentrasinya lebih rendah akibat ion yang terkontaminasi sekarang, sehingga endapan lebih murni. Postpresipitasi merupakan adanya suatu endapan kedua pada permukaan endapan pertama. Hal ini dapat terjadi dengan adanya campuran garam yang sukar larut.

Untuk mendapatkan endapan yang besar dan murni, yang dilakukan biasanya endapan didegrasi (didegest) atau dimatangkan yaitu dengan endapan yang dibiarkan kontak langsung dengan larutan induknya selama beberapa jam pada temperatur $60-70^{\circ} \mathrm{C}$.

b. Menyaring dan Mencuci Endapan

Endapan yang telah disaring, lalu dikotori oleh zat-zat yang mudah larut dan harus dihilangkan dengan cara pencucian endapan. Yang menjadi pada dasar pencucian adalah :

$\checkmark$ Dapat melarutkan zat pengotor dengan baik tetapi tidak melarutkan endapan dan dapat mencegah terjadinya presipitasi pada waktu pencucian.

$\checkmark$ Dapat menyebabkan adanya pertukaran ion-ion yang teradsorpsi sehingga diganti oleh ion-ion lain yang apabila pada pemanasan dapat menguap.

$\checkmark$ Endapan yang terjadi dapat disaring dengan kertas saring bebas abu, cawan penyaring dengan asbes atau penyaring gelas.

c. Penyaring dan Pemanasan Endapan

Kemudian endapan yang telah disaring, dicuci, dikeringkan, diabukan, dan dipijarkan sampai beratnya konstan. 
Pengeringan endapat dilakukan untuk menghilangkan air dan zat yang mudah menguap, sedangkan pemijaran dilakukan untuk merubah endapat tersebut ke dalam suatu senyawa kimia yang rumusnya dapat diketahui dengan pasti.

\subsection{Kondisi Pengendapan}

Adapun kondisi yang diperlukan agar dapat mengendapkan analit yang dilakukan dengan menggunakan pereaksi tertentu, antara lain :

a. Pengendapan harus dilakukan dalam larutan encer dengan memperhatikan kelarutan endapan, waktu yang diperlukan untuk penyaringan endapan, dan perlakuan-perlakuan lainnya yang harus dilakukan setelah proses pengendapan. Hal ini dapat dilakukan untuk meminimalisirkan kesalahan yang diakibatkan oleh kopresipitasi.

b. Pada pereaksi atau reagensia harus dihomogenkan secara perlahan-lahan sambil dilakukan pengadukan secara terusmenerus untuk menjaga tingkat lewat-jenuh kecil, dan dapat membantu pertumbuhan kristal yang besar. Sehingga dapat dengan mudah disaring dan memperoleh endapan kristalin yang berukuran besar.

c. Pengendapan dilakukan dalam larutan yang panas, sehinggan harus dipanaskan sampai tepat di bawah titik akhir atau sampai temperatur lain yang lebih mengentungkan.

d. Endapan kristalinharus dicerna atau didegras (digest) dalam penangas air. Proses ini dapat mengurangi efek 
kopresipitasi dan menghasilkan endapan yang lebih mudah disaring.

e. Endapan selanjutnya harus dicuci dengan larutan elektrolit yang sesuai dan encer.

f. Jika endapan yang dihasilkan ternyata masih terkontaminasi akibat kopresipitasi ataupun sebab lainnya, maka kesalahan dapat dilakukan dengan cara menguranginya dengan pelarut kembali menggunakan pelarut yang sesuai, dan lalu di endapkan kembali. Dengan ini dapat mengurangi jumlah pencemaran yang terdapat pada endapan.

\subsection{Tahap-tahap Analisis Gravimetri}

Secara umum, tahapan yang dilakukan dalam analisis gravimetri dengan cara pengendapan adalah :

a. Pelarutan analit

b. Pengaturan kondisi larutan; $\mathrm{pH}$, temperatur

c. Pembentukan endapan

Endapan terbentuk dari adanya penambahan pereaksi pengendapan secara berlebih yang bertujuan agar semua unsur/senyawa dapat terendapkan dengan sempurna. Syarat pengendapan dilakukan pada temperatur dan ph tertentu yang merupakan kondisi optimum reaksi pengendapan. Pada tahap ini merupakan tahap paling penting.

d. Digest (menumbuhkan kristal-kristal endapan)

Setelah terbentuk endapan, maka yang perlu dilakukan selanjutnya dalah penyempurnaan endapan. Cara ini dapat dilakukan dengan membiarkan larutan yang berisi endapan selama beberapa saat dalam penangas air atau waterbath. 
e. Penyaringan dan pencucian endapan

Pada langkah ini, endapan yang terbentuk diupayakan kasar/besar dengan mengatur kondisi larutan agar endapan yang terbentuk tidak terlalu cepat atau terlalu mudah. Pada umumnya endapan kasar lebih murni dari endapan yang halus.

f. Pengeringan/pemijaran atau pemanasan endapan agar mendapatkan endapan kering dengan susunan tertentu yang stabil dan spesifik sampai diperoleh berat konstan.

g. Pendinginan dan penimbangan endapan

h. Perhitungan kuantitats analit dalam sampel.

Endapan Bulky. Merupakan endapan dengan volume atau berat besar tetapi berasal dari analit yang sedikit. Endapan tersebut sering diupayakan untuk mengurangi kesalahan yang relatif dalam analisis.

Endapan Spesifik. Merupakan endapan yang terbentuk karena adanya pereaksi yang ditambahkan hanya dapat mengendapkan komponen yang dianalisis. Oleh sebab itu, edapan yang terbentuk tidak perlu diawali dengan pemisahan pada komponen-komponennya yang bisa saja akan ikut mengendap apabila dipakai sebagai pereaksi non spesifik.

Adapula syarat untuk analisis gravimetri sebagai berikut :
a. Kelarutan endapan sekecil mungkin
b. Kemurnian tinggi
c. Mempunyai susunan tetap, tertentu, dan stabil
d. Kristal endapan kasar
e. Endapan bulky
f. Endapan spesifik 
Endapan bulky dan endapan spesifik merupakan syarat terpenting dalam upaya mempermudah suatu analisis.

\subsection{Pereaksi Pengendapan Organik}

Pereaksi Pengendapan Organik. Prinsinya yaitu dengan adanya ion logam tertentu yang dapat membentuk senyawa kompleks organik dengan masa molekul relatif tinggi, sehingga dengan ion logam yang sedikit ini didapatkan endapan logam yang banyak. Pereaksi-pereaksi organik yang digunakan merupakan pereaksi yang mampu membentuk kelat. Berikut ini adalah beberapa pereaksi organik yang biasanya digunakan, yaitu dimetilglioksin, $\alpha$-benzeinoksin, kupferron, 8-hidroksikuinolin, asam antranilat, natrium-dietil-ditiokarbonat.

Kriteria Pemilihan Pereaksi Organik. Beberapa hal harus diperhatikan dalam pemilihan pereaksi organik, antara lain :

a. Pereaksi organik harus memiliki sifat selektif

b. Endapan organik tidak boleh mengandung pengotor kopresipitasi dan endapan ionik lainnya.

c. Ion logam dalam jumlah sedikit dapat diendapkan dalam jumlah (berat) yang besar, sehingga dapat dilakukan pengendapan pada tingkat mikro dan semimikro.

d. Pereaksi organik dapat dimodifikasi dengan penambahan rantai atau gugus lain. Aspek ini penting, contohnya digunakan untuk keperluan analisis selanjutnya.

\subsection{Aplikasi}

Analisis gravitrimetri telah banyak diaplikasikan untuk analisis kation dari unsur-unsur yang terdapat dalam sistem periodik. Metode analisis dapat digunakan untuk analisis kuantitatif 
bahan organik tertentu seperti kolesterol pada careal dan laktosa pada susu. Kolesterol sebagai steroid alkohol yang dapat diendapkan secara kuantitatif dengan saponin organik yang disebut digitonin. Selain itu juga dapat digunakan untuk menentukan kadar senyawa anorganik seperti kalsium, barium, klorin, magnesium, besi, nikel, dan lain-lain.

Metode gravimetri bukanlah metode analisis kuantitatif yang spesifik, sehingga dapat digantikan dengan analisis modern seperti spektroskopidan khomatografi. Meskipun demikian, metode gravimetri menjadi sudah pilihan karena peralatan dan prosedur pelaksanaannya yang sederhana. Analisis gravimetri pada saat ini juga masih banyak dietrapkan untuk analisis konstituen makro yang menghasilkan endapan $\mathrm{AgCl}, \mathrm{BaSO}_{4}, \mathrm{Fe}(\mathrm{OH})_{3}$.

Penentuan Berat Atom. Pada penentuan ini, dilakukan dengan memanfaatkan molekul tertentu dengan tingkat kemurnian yang tinggi. Molekul tersebut ditimbang dan presentase tiap komponen penyusunnya ditentukan secara gravimetrik. Perhitungan yang digunakan adalah sebagaimana prosedur gravimetri pada umumnya, kecuali degan adanya faktor-faktor berat atom dengan unsur tertentu sebagai salah satu faktor yang belum diketahui untuk ditentukan dengan cara ini.

Penentuan Magnesium sebagai Magnesium Fosfat Heksahidrat dan Pirofosfat. Dalam penentuan ini, larutan dingin (asidik) dari garam magnesium ditambah dengan diammonium hidrogenfosfat berlebih yang selanjutnya akan ditambahkan dengan larutan ammonia berlebih untuk mngendapkan ammonium magnesium fosfat heksahidrat pada temperatur ruang sebagai berikut : 


\section{$\mathrm{Mg}^{2+}+\mathrm{HPO}_{4}^{2-}+\mathrm{NH}_{4}^{+}+\mathrm{OH}^{-} \rightarrow \mathrm{MgNH}_{4} \mathrm{PO}_{4}+\mathrm{H}_{2} \mathrm{O}$}

Proses tersebut dilakukan pada suhu $15-30^{\circ} \mathrm{C}$ supaya untuk memastikan bahwa di dalam sistem tidak terdapat bentuk monohidrat $\mathrm{MgNH}_{4} \mathrm{PO}_{4} \cdot \mathrm{H}_{2} \mathrm{O}$. garam ini memiliki sifat yan stabil pada kondisi suhu di atas $62{ }^{\circ} \mathrm{C}$. Apabila hal itu terjadi, maka sistem harus segera didiamkan pada suhu ruang selama 24 jam yang bertujuan untuk mengubahnya ke bentuk heksahidrat.

Endapan tersebut memiliki kelarutan yang relatif tinggi berkisar $65 \mathrm{mg}^{\mathrm{dm}}{ }^{-3}$ pada suhu $10{ }^{\circ} \mathrm{C}$ dalam air suling (akuades). Keberadaan ammonium ini akan menurunkan jumlah tersebut, dan memiliki sifat kecenderungan terhadap pembentukan larutan lewat jenuh; oleh karen aitu, larutan hendaknya didiamkan dulu selama beberapa jam sebelum dilakukannya filtrasi. Endapan dicuci dengan larutan ammonia dan ditimbang sebagai bentuk heksahidrat atau pirofosfat. Untuk pirofosfat, endapan dipanaskan pada suhu yang lebih tinggi yaitu lebih dari $1000{ }^{\circ} \mathrm{C}$ selama satu jam supaya dapat terbentuk magnesium pirofosfat.

Penentuan Besi. Prosedur analisis dilakukan dengan mengendapkan besi sebagai besi(III) hidroksida, kemudian dipijarkan dengan suhu yang tinggi agar menjadi $\mathrm{Fe}_{2} \mathrm{O}_{3}$. Pada anlisis batuan, unsur-unsur yang mengganggu besi harus dipisahkan terlebih dahulu. Selanjutnya, bijih besi biasanya dilarutkan dalam asam klorida dan asam nitrat yang memiliki fungsi untuk mengoksidasi besi(II) menjadi besi(III). Lalu, larutan yang mengandung besi(III) akan ditambahkan dengan larutan ammonia sedikit demi sedikit hingga membentuk endapan $\mathrm{Fe}(\mathrm{OH})_{3}$. Kemudian, endapan dicuci dengan air yang sedikit mengandung ammonium nitrat untuk mencegah presipitasi. Penyaringan dilakukan dengan menggunakan kertas saring, lalu kertas dan 
endapan dibakar pada suhu yang sangat tinggi untuk membentuk $\mathrm{Fe}_{2} \mathrm{O}_{3} \cdot \mathrm{p}$

Penentuan Klorida. Ion klorida dalam larutan diendapkan sebagai perak klorida $(\mathrm{AgCl})$. Endapan yang terbentuk pertama-tama akan berbentuk koloid tetapi lama-kelamaan akan membentuk gumpalan.

$$
\mathrm{Ag}^{+}(\mathrm{aq})+\mathrm{Cl}^{-}(\mathrm{aq}) \rightarrow \mathrm{AgCl}(\mathrm{s})
$$

Endapan yang terbentuk lebih mudah dicuci dengan menggunakan larutan asam nitrat $\left(\mathrm{HNO}_{3}\right)$ encer. Perak klorida yang terbentuk selanjutnya disaring melalui sintered-glass cawan, tidak menggunakan kertas saring biasa karena $\mathrm{AgCl}$ mudah direduksi menjadi Ag bebas oleh karbon dalam kertas saring selama proses pembakaran kertas saring.

Aplikasi dalam Analisis Sistematik. Dengan metode gravimetri, bisa juga digunakan untuk menganalisis suatu unsurunsur berupa kation dan anion, seperti pada metode analisis kuantitatif untuk mengidentifikasikan ion-ion yang diendapkan dengan reagensia pengendap masing-masing.

\subsection{Rangkuman}

$>$ Analisi gravitrimetri atau analisis kuantitatif berdasarkan bobot, yaitu dimana suatu proses isolasi serta penimbangan suatu unsur atau senyawa tertentu dari unsur tersebut dalam bentuk yang semurni mungkin.

$>$ Gravimetri adalah pemeriksaan jumlah zat dengan cara penimbangan hasil reaksi pengendapan. 
> Metode gravimetri merupakan suatu metode yang digunakan dalam analisis gravimetri yang digunakan untuk menentukan kuantitas analit secara konvensional.

> Tahapan yang dilakukan dalam analisis gravimetri dengan cara pengendapan adalah pelarutan analit, pengaturan $\mathrm{pH}$ dan temperature, pembentukan endapan, digest (menumbuhkan kristal-kristal endapan), penyaringan dan pencucian endapan, pengeringan/pemijaran atau pemanasan endapan, pendinginan dan penimbangan endapan dan perhitungan kuantitats analit dalam sampel.

\subsection{Latihan Soal}

Kerjakanlah soal di bawah ini sebagai sarana pemahaman anda terhadap materi Analisis Gravimetri!

1. Suatu sampel padatan dilakukan analisis, dalam sampel diketahui mengandung klor. Sampel kemudian dilarutkan sedemikian rupa dalam aquades hingga volume larutan menjadi $150 \mathrm{~mL}$. Hasil analisis diperoleh endapan $\mathrm{AgCl}$ sebesar $75 \mathrm{mg}$. Hitunglah prosentase kesalahan dalam analisis tersebut!

2. Jelaskan apa pentingnya analisis gravimetri?

3. Besi (IV) oksida $\left(\mathrm{Fe}_{3} \mathrm{O}_{4}\right)$ murni diolah menjadi besi (III) oksida $\left(\mathrm{Fe}_{2} \mathrm{O}_{3}\right)$ sebesar 0,5 g. Berapakah massa besi (IV) oksida $\left(\mathrm{Fe}_{3} \mathrm{O}_{4}\right)$ murni yang dibutuhkan? $2 \mathrm{Fe}_{3} \mathrm{O}_{4}+1 / 2 \mathrm{O}_{2} \rightarrow 3 \mathrm{Fe}_{2} \mathrm{O}_{3}$ 


\section{BAB 8}

\section{ANALISIS VOLUMETRI}

\section{Sub-Capaian Pembelajaran Mata Kuliah}

1. Mahasiswa mampu mengetahui hukum-hukum yang mendasari analisis volumetri gas

2. Mahasiswa mampu melakukan perhitungan volumetri.

3. Mahasiswa mampu melakukan perhitungan analisis gas dengan metode absorpsi dan pembakaran

\subsection{Hukum-hukum Gas Ideal}

Pada bab ini, akan mempelajari hukum-hukum tentang gas, yaitu hukum Boyle, hukum Charles, hukum Gay Lussac, dan hukum Boyle-Gay Lussac. Akan tetapi,dalam setiap penyelesaian soal-soal seca umum hukum yang kita selalu gunakan adalah hukum BoyleGay Lussac, karena hukum tersebut merupakan gabungan dari setiap kondisi yang berlaku pada ketiga hukum sebelumnya.

a. Hukum Boyle

Hukum Boyle pertama kali dicetuskan oleh Robert Boyle (1627-1691) yang berasal dari Inggris, sebagai penghargaan atas jasa fisikawan dan kimiawiannya.

Tinjau suatu gas yang ditempatkan dalam suatu bejana tertutup pada suhu konstan seperti ditunjukkan pada Gambar 8.1 
Gambar 8.1 Perubahan Tekanan dan Volume Pada Suhu Konstan.

Pada saat pistol digerakkan ke bawah, maka tekanan (P) gas akan naik dan volume (V) gas akan turun. Kemudian, jika pistol digerakkan secara perlahan-lahan, maka gas akan tetap dalam keseimbangan termal dengan reservior sehingga suhu gas selama proses berlangsung dapat dipertahankan konstan. Pengukuran voleme (V) gas kita lakukan untuk tiap-tiap kenaikan tekanan (P). Hasil percobaan ini menyatakan bahwa :

“Apabila suhu gas yang berada dalam bejana tertutup dipertahankan konstan, maka tekanan gas berbalik terbalik dengan volumenya."

Pernyataan ini dapat dituliskan secara matematis sebagai berikut.

$$
\begin{gathered}
\mathrm{P} \propto \frac{1}{\mathrm{~V}} \\
\mathrm{PV}=\text { konstan }
\end{gathered}
$$

Untuk gas yang berada dalam dua keadaan kesimbangan yang berbeda pada suhu konstan, maka diperoleh :

$$
P_{1} V_{1}=P_{2} V_{2}
$$

Keterangan :

$\mathrm{P}_{1}=$ Tekanan gas pada keadaan $1\left(\mathrm{~N} / \mathrm{m}^{2}\right)$

$\mathrm{V}_{1}=$ Volume gas pada keadaan $1\left(\mathrm{~m}^{3}\right)$

$\mathrm{P}_{2}=$ Tekanan gas pada keadaan $2\left(\mathrm{~N} / \mathrm{m}^{2}\right)$

$\mathrm{V}_{2}=$ Volume gas dalam keadaan $2\left(\mathrm{~m}^{3}\right)$ 
Persamaan (8.1) berlaku untuk hampir semua gas dengan massa jenis yang rendah dan apabila dilukiskan dalam grafik, maka hasilnya tampak seperti Gambar 8.2. Kurva yang terjadi disebut kurva isotermal yang artinya bersuhu sama.

Gambar 8.2 Grafik Hubungan Tekanan dan Volume Gas Pada Suhu Konstan (Isotermal).

b. Hukum Charles

Hukum Charles pertama kali dicetuskan oleh Jacques Charles (1746-1823) yang berasal dari Prancis, sebagai penghargaan atas jasa fisikawannya.

Tinjau suatu gas yang ditempatkan dalam suatu bejana tertutup seperti ditunjukkan pada Gambar 8.3 di bawah ini, beban piston yang dapat bergerak bebas diletakkan pada bagian bejana yang berpenampang kecil yang digunakan untuk mempertahankan agar tekanan gas selama proses berlangsung bernilai konstan. Pada saat bejana dipanaskan, mula-mula tekanan $(P)$ gas naik. Sehingga kenaikan tekanan $(P)$ tersebut akan mendorong piston ke atas sampai tekanan (P) gas dalam bejana sama degan tekanan (P) mula-mula. Kemudian, pengukuran volume (V) gas dilakukan untuk tiap-tiap kenaikan suhu (T). Hasil perncobaan ini menyatakan bahwa :

"Apabila tekanan (P) gas yang berada dalam bejana tertutup dipertahankan konstan, maka volume (V) gas sebanding dengan suhu (T) mutlaknya." 
Gambar 8.3 Perubahan Suhu dan Volume Gas Pada Tekanan Konstan.

Pernyataan di atas, dapat dituliskan secara matematis sebagai berikut.

$$
\begin{gathered}
\mathrm{V} \propto \mathrm{T} \\
\frac{\mathrm{V}}{\mathrm{T}}=\text { konstan }
\end{gathered}
$$

Untuk gas yang berada dalam dua keadaan keseimbangan yang berbeda pada tekana konstan, maka diperoleh :

Keterangan :

$$
\frac{V_{1}}{T_{1}}=\frac{V_{2}}{T_{2}}
$$

$\mathrm{V}_{1}=$ Volume gas pada keadaan $1\left(\mathrm{~m}^{3}\right)$

$\mathrm{T}_{1}=$ Suhu mutlak gas pada keadaan $1(\mathrm{~K})$

$\mathrm{V}_{2}=$ Volume gas pada keadaan $2\left(\mathrm{~m}^{3}\right)$

$\mathrm{T}_{2}=$ Suhu mutlak gas dalam keadaan $2(\mathrm{~K})$

Persamaan (8.2) apabila dilukiskan dalam grafik, maka hasilnya tampak seperi Gambar 8.4. Kurva yang terjadi disebut kurva isobarik yang artinya bertekanan sama.

Gambar 8.4 Grafik Hubungan Volume dan Suhu Gas Pada Tekanan Konstan (Isobarik).

c. Hukum Gay Lussac 
Hukum Gay Lussac pertama kali dicetuskan oleh Joseph Gay Lussac (1778-1850) yang berasal dari Prancis, sebagai penghargaan atas jasa kimiawannya.

Tinjau suatu gas yang ditempatkan dalam suatu bejana tertutup yang terbuat dari baja di mana perubahan volume (V) bejana akibat perubahan suhu (T) dapat diabaikan seperti ditunjukkan pada Gambar 8.5.

Gambar 8.5 Perubahan Suhu dan Tekanan Pada Volume Konstan.

Suatu tera tekanan dihubungkan langsung dengan bejana yang sudah dikalibrasi untuk membaca tekanan mutlak gas dalam bejana. Kemudian, bejana tersebut dipanaskan sehingga suhu $(T)$ dan tekanan $(P)$ gas dalam bejana naik. Pengukuran tekanan (P) gas dilakukan untuk tiap-tiap kenaikan suhu (T). Hasil percobaan ini menyatakan bahwa :

"Apabila volume (V) gas yang berada dalam bejana tertutup dipertahankan konstan, maka tekanan $(P)$ gas sebanding dengan suhu (T) mutlaknya."

Pernyataan ini, dapat dituliskan secara matematis sebagai berikut.

$$
\begin{gathered}
\mathrm{P} \propto \mathrm{T} \\
\frac{\mathrm{P}}{\mathrm{T}}=\text { konstan }
\end{gathered}
$$


Untuk gas yang berada dalam dua keadaan keseimbangan yang berbeda pada volume (V) konstan, maka diperoleh :

$$
\frac{P_{1}}{T_{1}}=\frac{P_{2}}{T_{2}}
$$

Keterangan :

$$
\begin{aligned}
& \mathrm{P}_{1}=\text { Tekanan gas pada keadaan } 1\left(\mathrm{~N} / \mathrm{m}^{2}\right) \\
& \mathrm{T}_{1}=\text { Suhu mutlak gas pada keadaan } 1(\mathrm{~K}) \\
& \mathrm{P}_{2}=\text { Tekanan gas pada keadaan } 2\left(\mathrm{~N} / \mathrm{m}^{2}\right) \\
& \mathrm{T}_{2}=\text { Suhu mutlak gas dalam keadaan } 2(\mathrm{~K})
\end{aligned}
$$

Persamaan (8.3) apabila dilukiskan dalam grafik, maka hasilnya tampak seperi Gambar 8.6. Kurva yang terjadi disebut kurva isokhorik yang artinya bervolume sama.

\section{Gambar 8.6 Grafik Hubungan Tekanan dan Suhu Gas Pada Volume Konstan (Isokhorik).}

\section{d. Hukum Boyle-Gay Lussac}

Apabila hubungan antara tekanan (P), volume (V), dan suhu ( $T$ ) gas dalam Persamaan (8.1), (8.2), dan (8.3) digabungkan, maka diperoleh persamaan (7.4) yang disebut Hukum Boyle-Gay Lussac.

$$
\frac{\mathbf{P}_{1} V_{1}}{T_{1}}=\frac{\mathbf{P}_{2} V_{2}}{T_{2}}
$$




\subsection{Analisis Volumetrik Gas}

Pada metode volumetrik gas, meliputi cara-cara analisis dengan reaksi kimia yang menghasilkan gas. Dasar penghitungan jumlah substan sampel menggunakan jumlah zat yang terukur.

Metode Absorbsi. Merupakan suatu campuran gas yang dilewatkan pada suatu seri adsorben dengan temperatur dan tekanan yang dijaga konstan selama pengukuran. Selisis pada volume gas sebelum dan sesudah dilewatkan pada adsorben merupakan petunjuk jumlah gas yang terserap dan jumlah tersebut biasanya diekspresikan sebagai persen volume.

Tabel 8.1 Beberapa Reagen Sebagai Adsorben Gas

\begin{tabular}{ll}
\hline \multicolumn{1}{c}{ Gas } & \multicolumn{2}{c}{ Reagen } \\
\hline Karbon dioksida & $\mathrm{NaOH}, \mathrm{KOH}$ \\
$\begin{array}{l}\text { Hidrokarbon tak } \\
\text { jenuh (illuminant) }\end{array}$ & $\begin{array}{l}\mathrm{Air} \text { brom, Asam sulfat berasap, } \\
\mathrm{Ag}_{2} \mathrm{SO}_{4}\end{array}$ \\
$\mathrm{CH}_{4}, \mathrm{C}_{2} \mathrm{H}_{6}$ & $\mathrm{CuO}$ pada $600{ }^{\circ} \mathrm{C}$ \\
Oksigen & $\begin{array}{l}\text { Larutan pyrogallol alkalin, Fosfor } \\
\text { kuning, } \mathrm{CaCl}, \mathrm{Natrium} \mathrm{tionit}\end{array}$ \\
Karbon monoksida & $\mathrm{CuCl}$ amoniakal, CuO pada $285^{\circ} \mathrm{C}$ \\
Hidrogen & $\begin{array}{l}\text { Busa paladium, Larutan palladous } \\
\text { chloride, Larutan colloidal palladium }\end{array}$ \\
\hline
\end{tabular}

(Sumber : Widodo, dkk, 2009: 148)

Metode Pembakaran. Apabila suatu campuran gas yang mengandung satu atau lebih komponen, yang dapat terbakar oleh oksigen, maka komposisi campuran ini dapat ditentukan dengan pengukuran penurunan volume gas, jumlah $\mathrm{CO}_{2}$ terbentuk, volume oksigen yang dikonsumsi atau gabungan pengukuran tersebut. Reaksi pembakaran yang terjadi sebagai berikut : 


$$
2 \mathrm{CO}+\mathrm{CO}_{2} \rightarrow 2 \mathrm{CO}_{2}
$$

Maka, menurut hukum Gay-Lussac adalah dua bagian pada volume $\mathrm{CO}$ dibakar dengan atu bagian $\mathrm{O}_{2}$, sehingga menghasilkan dua bagian $\mathrm{CO}_{2}$. Pembakaran ini disertai dengan kontraksi atau penurunan setengah volume karbon monoksida yang ada dan menghasilkan sejumlah karbon dioksida sebanyak volume karbon monoksida awal.

Tabel 8.2 Reaksi Pembakaran dan Kontraksi Volume Gas

\begin{tabular}{|c|c|c|c|c|}
\hline $\begin{array}{c}\text { Reaksi } \\
\text { Pembakaran }\end{array}$ & $\begin{array}{c}\text { Volume } \\
\text { Gas }\end{array}$ & $\begin{array}{c}\mathrm{O}_{2} \text { yang } \\
\text { Diperlukan }\end{array}$ & Kontraksi & $\begin{array}{c}\mathrm{CO}_{2} \text { yang } \\
\text { Dihasilkan }\end{array}$ \\
\hline $2 \mathrm{H}_{2}+\mathrm{O}_{2} \rightarrow 2 \mathrm{H}_{2} \mathrm{O}$ & 1 & 0,5 & $\overline{1,5}$ & 0 \\
\hline $2 \mathrm{CO}+\mathbf{O}_{2} \rightarrow \mathbf{2} \mathrm{CO}_{2}$ & 1 & 0,5 & 0,5 & 1 \\
\hline $\mathrm{CH}_{4}+2 \mathrm{O}_{2} \rightarrow \mathrm{CO}_{2}+\mathrm{H}_{2} \mathrm{O}$ & 1 & 2,0 & 2,0 & 1 \\
\hline $\begin{array}{l}2 \mathrm{C}_{2} \mathrm{H}_{2}+5 \mathrm{O}_{2} \rightarrow 4 \mathrm{CO}_{2}+ \\
\mathrm{H}_{2}\end{array}$ & 1 & 2,5 & 1,5 & 2 \\
\hline $\begin{array}{l}\mathrm{C}_{2} \mathrm{H}_{4}+3 \mathrm{O}_{2} \rightarrow 2 \mathrm{CO}_{2}+ \\
2 \mathrm{H}_{2} \mathrm{O}\end{array}$ & 1 & 3,0 & 2,0 & 2 \\
\hline $\begin{array}{l}2 \mathrm{C}_{2} \mathrm{H}_{6} \\
7 \mathrm{O}_{2} \rightarrow 4 \mathrm{CO}_{2}+\mathrm{H}_{2} \mathrm{O}\end{array}$ & 1 & 3,5 & 2,5 & 2 \\
\hline $\begin{array}{l}3 \mathrm{C}_{2} \mathrm{H}_{6}+9 \mathrm{O}_{2} \rightarrow 6 \mathrm{CO}_{2}+ \\
6 \mathrm{H}_{2} \mathrm{O}\end{array}$ & 1 & 4,5 & 2,5 & 3 \\
\hline $\begin{array}{l}\mathrm{C}_{3} \mathrm{H}_{8}+5 \mathrm{O}_{2} \rightarrow 3 \mathrm{CO}_{2}+ \\
4 \mathrm{H}_{2} \mathrm{O}\end{array}$ & 1 & 5,0 & 3,0 & 3 \\
\hline $\begin{array}{l}2 \mathrm{C}_{4} \mathrm{H}_{10}+13 \mathrm{O}_{2} \rightarrow 8 \mathrm{CO}_{2}+ \\
10 \mathrm{H}_{2} \mathrm{O}\end{array}$ & 1 & 6,5 & 3,5 & 4 \\
\hline
\end{tabular}

(Sumber : Widodo, dkk, 2009: 280)

\subsection{Rangkuman}

$>$ Hukum-hukum tentang gas, yaitu hukum Boyle, hukum Charles, hukum Gay Lussac, dan hukum Boyle-Gay Lussac. 
$>$ Hukum Boyle menyatakan apabila suhu gas yang berada dalam bejana tertutup dipertahankan konstan, maka tekanan gas berbalik terbalik dengan volumenya.

$>$ Hukum Charles menyatakan apabila tekanan (P) gas yang berada dalam bejana tertutup dipertahankan konstan, maka volume (V) gas sebanding dengan suhu (T) mutlaknya.

$>$ Hukum Gay Lussac menyatakan apabila volume (V) gas yang berada dalam bejana tertutup dipertahankan konstan, maka tekanan $(\mathrm{P})$ gas sebanding dengan suhu (T) mutlaknya.

$>$ Hukum Boyle-Gay Lussac merupakan hukum gabungan antara hokum Boyle dan hokum Gay Lussac yaitu antara tekanan $(\mathrm{P})$, volume $(\mathrm{V})$, dan suhu $(\mathrm{T})$ gas digabung menjadi satu.

$>$ Metode Absorbsi. Merupakan suatu campuran gas yang dilewatkan pada suatu seri adsorben dengan temperatur dan tekanan yang dijaga konstan selama pengukuran.

> Metode Pembakaran. Apabila suatu campuran gas yang mengandung satu atau lebih komponen, yang dapat terbakar oleh oksigens

\subsection{Latihan Soal}

Kerjakanlah soal di bawah ini sebagai sarana pemahaman anda terhadap materi Analisis Volumetri!

1. Sejumlah gas ideal mula-mula bersuhu $28^{\circ} \mathrm{C}$ pada ruang tertutup. Agar tekanan menjadi 6 kali semula, maka tentukan suhu ruangan tersebut!

2. Suatu gas ideal yang menempati ruang dengan volume $\mathrm{V}$, tekanan $\mathrm{P}$, dan suhu $\mathrm{T}$. Kemudian gas tersebut 
dipanaskan hingga volumenya menjadi $3 / 4 \quad \mathrm{~V}$ dan tekanannya menjadi $5 / 3 \mathrm{P}$. Tentukan suhu gas setelah pemanasan!

3. Sebuah ban sepeda motor diukur tekanannya sebesar 3 atm pada suhu $27^{\circ} \mathrm{C}$. Kemudian sepeda motor tersebut dikendarai lalu suhu di dalam ban naik menjadi $51^{\circ} \mathrm{C}$. Jika pemuaian diabaikan, maka tentukan tekanan udara yang ada di dalam ban sepeda motor tersebut! 


\section{BAB 9}

\section{ANALISIS KOLOMETRI}

\section{Sub-Capaian Pembelajaran Mata Kuliah}

1. Mahasiswa mampu memahami dasar-dasar metode kolorimetri.

2. Mahasiswa mampu menjelaskan fenomena absorbsi cahaya oleh larutan.

3. Mahasiswa mampu menjelaskan dan memahami hukum Lambert-Beer dan syarat berlakunya.

4. Mahasiswa mampu melakukan analisis kolorimetri dengan metode deret standar, pengenceran, titrasi, dan penyeimbangan untuk penentuan konsentrasi analit.

\subsection{Dasar-dasar Analisis Kolorimetri}

Pada penetapan kolorimetrik, banyaknya unsur atau ion yang ada ditentukan dari intensitas warna larutan yang disebabkan oleh adanya senyawa yang berwarna atau telah dibuat menjadi berwarna. Semakin kuat intensitas warnanya, maka semakin besar pula konsentrasi unsur atau ion tersebut dalam larutan. Apabila pada dua larutan pada kondisi dan kandungan senyawa berwarna yang sama memiliki intensitas warna yang sama, maka konsentrasi unsur atau ion yang terjadi di dalamnya juga sama. Oleh karena itu, jika dibuat dengan pengenceran warna larutan analit yang sama dengan warna larutan standar, maka dapat diperkirakan bahwa konsentrasi kedua larutan tersebut adalah sama. Jika pengencerannya diketahui, maka dapat dengan mudah menghitung 
konsentrasi analit. Metode kolorimetri ini biasanya meliputi penyamaan warna analit dengan larutan standar.

Larutan berwarna dapat terbentuk setelah zat tersebut dilarutkan (seperti larutan $\mathrm{MnO}_{4}^{-}, \mathrm{CrO}_{4}^{2-}$, dan sebagainya) atau molekul yang mempunyai warna yang cukup intensif. Namun, biasanya yang lebih sering terlihat warna harus dibuat dengan penambahan beberapa reagen yang bereaksi seacra kimia dengan unsur atau ion yang ditentukan. Contohnya, pada penentuan besi secara kolorimetri, ammonium tiosulfat yang ditambahkan pada larutan analit; yang bereaksi dengan $\mathrm{Fe}^{3+}$ membentuk $\mathrm{Fe}(\mathrm{CNS})_{3}$ yang memiliki warna merah darah yang intensif, titanium yang ditentukan dengan penambahan hidrogen peroksida $\left(\mathrm{H}_{2} \mathrm{O}_{2}\right)$, yang membentuk warna jingga kuning dengan pembentukan asam pertitanat $\left[\mathrm{H}_{2}\left(\mathrm{TiO}_{2}\left(\mathrm{SO}_{2}\right)_{2}\right)\right]$. Apabila terdapat warna larutan yang kurang intensif, maka perlu penggunaan reagen yang sesuai untuk memberikan warna larutan menjadi intensif. Contohnya, garam tembaga yang memiliki warna biru, akan tetapi warna tersebuat kurang intensif (lemah). Oleh karena itu, penetapan kolorimetri tembaga akan mengubah ion $\mathrm{Cu}^{2+}$ dengan $\mathrm{NH}_{4} \mathrm{OH}$ menjadi kompleks berwarna $\left[\mathrm{Cu}\left(\mathrm{NH}_{3}\right)_{4}\right]^{2+}$ yaitu berwarna biru langit.

Reaksi yang melibatkan pembentukan ion kompleks berwarna kuat dengan mereaksikan kation logam dengan ammonia, ion $\mathrm{CNS}^{-}$, atau berbagai senyawa organik sering digunakan untuk penentuan kolometri. Diketahui bahwa ion kompleks dapat terdiosiasi menjadi penyusun ion sederhananya (ion atau molekul). Contohnya, pada ion $\left[\mathrm{Cu}\left(\mathrm{NH}_{3}\right)_{4}\right]^{2+}$ yang terurai sebagian dalam air sebagai berikut:

$$
\left[\mathrm{Cu}\left(\mathrm{NH}_{3}\right)_{4}\right]^{2+} \leftrightarrow \mathrm{Cu}^{2+}+4 \mathrm{NH}_{3}
$$


Adapun juga diketahui bahwa peruraian kompleks dapat dicirikan olek konstanta ketidakstabilannya. Dalam hal ini, konstanta ketidakstabilannya dirumuskan sebagai berikut:

$$
\frac{\left[\mathrm{Cu}^{2+}\right]\left[\mathrm{NH}_{\mathrm{g}}\right]^{4}}{\left[\mathrm{Cu}\left(\mathrm{NH}_{\mathrm{g}}\right)_{4}\right]^{2+}}=\mathrm{K}_{\mathrm{Inst}}=5 \times 10^{-14}
$$

Sehingga, semakin kecil nilai $\mathrm{K}_{\text {Inst }}$ maka semakin kecil pula kompleks yang terurai dan kompleksnya semakin stabil.

Nilai $\mathrm{K}_{\text {Inst }}$ kompleks berwarna sangat penting pada analisis kolorimetri ini. Sehingga, jika semakin rendah nilai $\mathrm{K}_{\text {Inst }}$ maka semakin sempurna reaksi pembentukan kompleks yang terjadi. Oleh karena itu, agar kompleks dengan ion $\mathrm{K}_{\text {Inst }}$ tidah rendah maka dilakukan dengan penambahan reagen sedikit berlebih untuk mengubah ion menjadi kompleksnya. Sedangkan pada kompleks dengan $\mathrm{K}_{\text {Inst }}$ besar, maka warna larutan kompleks yang terjadi sangat tergantung pada banyaknya kelebihan reagen yang ditambahkan. Ketika analisis kolorimetri menggunakan reaksi pembentukan kompleks, maka itu berpengaruh penting dalam hal pemilihan pelarut yang sesuai dan dapat mempengaruhi $\mathrm{K}_{\text {Inst }}$ kompleks, pH larutan, kondisi reaksi (seperti konsentrasi reagen yang digunakan), dan sebagainya.

Selain pada reaksi pembentukan kompleks, reaksi lain seperti reduksi-oksidasi (redoks), sintesis organik juga sering digunakan dalam kolorimetri. Contohnya, mangan dan krom ditentukan secara kolorimetri denga mengoksidasi menjadi ion $\mathrm{MnO}_{4}^{-}$dan $\mathrm{CrO}_{4}^{2-}$ yang berwarna, penentuan nitrit ini didasarkan pada reaksi dengan reagen organik $\alpha$-naftilamin dan asam sulfanilat, sehingga membentuk pewarna merah yang kuat dengan ion $\mathrm{NO}_{2}^{-}$. Biasanya juga digunakan reaksi yang dapat melibatkan 
pembentukan senyawa peroksida berwarna, seperti asam pertitanat $\left[\mathrm{H}_{2}\left(\mathrm{TiO}_{2}\left(\mathrm{SO}_{2}\right)_{2}\right)\right]$ dalam penetapan titanium.

Metoda kolorimetri ini sangat sensitif, artinya bahwa metoda ini sangat sesuai untuk penetapan unsur pada konsentrasi sangat rendah, disamping sederhana dan lebih cepat daripada penetapan dengan gravimetri dan volumetri. Selain itu ada juga metoda kuantitatif lain yang terkait dengan kolorimetri, seperti nefelometri dan turbidimetri. Perbedaan pada keduanya adalah bahwa nefelometri dan turbidimetri didasarkan pada reaksi yang melibatkan pembentukan senyawa sukar larut dan jumlah analit yang dihitung dari turbiditas yang dihasilkan dalam larutan dengan membandingkan dengan turbiditas larutan standar yang sesuai.

Dalam penentuan turbidimetri larutan tersebut diuji dengan melewatkan cahaya, berkurangnya intensitas cahaya disebabkan oleh adanya partikel tersuspensi fasa padatan yang diukur. Sedangkan pada nefelometri, penetapan kadar analit larutan diuji dengan arah tegak lurus dengan berkas sinar. Dalam hal ini yang diamati intensitas cahaya yang dihamburkan oleh partikel fasa padatan.

Landasan fisik ketiga metoda tersebut adalah pengukuran kuantitas cahaya yang diserap atau dihamburkan oleh partikel zat terlarut atau tersuspensi dalam larutan. Ketiganya metoda tersebut dikenal dengan metoda fotometri. Dalam hal ini kolorimetri yang akan ditinjau. Dalam penetapan kolorimetri warna larutan analit dan standar dibandingkan dengan cara visual atau dengan bantuan fotosel, yaitu instrumen yang memiliki karakter apabila ketika terkena cahaya akan menghasilkan arus listrik, kekuatan arusnya tergantung pada intensitas cahaya yang datang. 
Sehubungan dengan metoda pengamatan yang digunakan dapat dibedakan antara kolorimetri visuak dan fotokolorimetri. Pada kolorimetri visual, hasil penentuan sangat tergantung pada karakteristik subyektif dari analis. Kesalahan yang dipicu akibat kelelahan pada mata, maka berpengaruh kuat pada presisi penetuan. Sehingga kesalaha relatif pada kolorimetri visual cukup tinggi. Kesalahan relatif sebaiknya tidak melebihi $5 \%$. Begitu sebaliknya, pada metode fotokolorimetri lebih obyektif dan memberikan hasil yang lebih presisi, disamping itu dapat mempermudah kerja analis.

\subsection{Hukum Abdorbsi Cahaya oleh Larutan}

Apabila cahaya monokromatis dengan intensitas $I_{o}$ yang mengenai lapisan homogen zat, maka sebagian cahaya akan dipantulkan $\left(I_{r}\right)$, diserap $\left(I_{a}\right)$, dan diteruskan $\left(I_{t}\right)$ melewati lapisan tersebut. Dalam hal ini larutan cair, biasanya digunakan dalam kolorimetri, $\mathrm{I}_{\mathrm{r}}$ kecil dibandingkan $\mathrm{I}_{\mathrm{a}}$ dan $\mathrm{I}_{\mathrm{t}}$, sehingga yang terjadi sebagai berikut :

$$
\mathrm{I}_{\mathrm{o}} \approx \mathrm{I}_{\mathrm{a}}+\mathrm{I}_{\mathrm{t}}
$$

Besarnya $I_{a}$ tergantung adanya larutan molekul atau ion zat berwarna yang menyerap cahaya lebih kuat daripada pelarut (berupa air, alkohol, ether, dll). Sehingga setelaj melewati larutan berkas cahaya tersebut intensitasnya akan berkurang; berkurangnya intensitas ini akan meningkat dengan adanya banyak suatu molekul atau ion zat berwarna yang ditemui dalam lintasan cahaya, dan oleh sebab itu berkurangnya intensitas juga tergantung pada konsentrasi dan tebal lapisan larutan (b) yang dilewati oleh cahaya. Hubungan tersebut dapat ditunjukkan dengan rumus sebagai berikut :

$$
\log \frac{\mathrm{I}_{\mathrm{O}}}{\mathrm{I}_{\mathrm{t}}}=\varepsilon b C
$$


Besar $\log \frac{\mathrm{I}_{\mathrm{o}}}{\mathrm{I}_{\mathrm{t}}}$ merupakan suatu ukuran berkurangnya cahaya ketika melewati larutan, biasanya dikenal dengan absorbansi A. Pada konstanta $\varepsilon$ sifatnya tergantung pada zat penyerap dan panjang gelombang cahaya. Apabila konsentrasi $\mathrm{C}$ dinyatakan dalam mol per liter, maka konstanta tersebut dikenak dengan absorptivitas molar larutan.

Rumus di atas merupakan ungkapan dari hukum absorpsi cahaya oleh larutan berwarna. Hukum Lambert-Beer menyatakan bahwa kerapatan optik suatu larutan sebanding dengan hasil konsentrasi zat penyerap (berwarna) dan ketebalan lapisan larutan. Sehingga dapat dirumuskan sebagai berikut :

$$
\begin{gathered}
\frac{\mathrm{I}_{0}}{\mathrm{I}_{\mathrm{t}}}=10^{\mathrm{abc}} \\
\mathrm{I}_{\mathrm{t}}=\mathrm{I}_{\mathrm{o}} \times 10^{\mathrm{gbc}}
\end{gathered}
$$

\subsection{Syarat Penggunaan Hukum Lambert-Beer}

Berikut adalah syarat penggunaan hukum Lambert-Beer:

a. Pengaruh Media $\mathrm{pH}$

Metoda penyeimbangan warna hanya berlaku pada rentang konsentrasi yang luas apabila struktur ion atau molekul berwarna tidak berubah terhadap perubahan konsentrasi, seperti pada permanganat, kromat dan beberapa pewarna organik. Namun, seiring dijumpai zat berwana telah mengalami perubahan kimia yang memepengaruhi watnanya ketika konsentrasi divariasi. Artinya, larutan seperti itu tidak mengikuti hukum Lambert-Beer. Dalam kasus seperti itu absortivitas molar $\varepsilon$, dalam hukum ini harus dibuat tetap untuk zat yang diinginkan, akan berubah dengan konsentrasi. Sehingga 
persamaan 4 tersebut tidak dapat diterapkan dan metoda pengeimbangan tidak dapat digunakan.

Sebagai ilustrasi, akan ditinjau dari contoh asam pikrat $\left(\mathrm{C}_{6} \mathrm{H}_{2}\left(\mathrm{NO}_{2}\right)_{3} \mathrm{OH}\right)$ yang merupakan golongan dari asam lemah. Untuk memudahkan penulisannya, maka selanjutnya hanya digunakan HA untuk asam tersebut. Ketika asam ini dilarutkan, kesetimbangan yang terjadi sebagai berikut :



$$
\frac{\left[\mathrm{H}^{+}\right]\left[\mathrm{A}^{-}\right]}{[\mathrm{HA}]}=\mathrm{K}
$$

Persamaan tersebut menunjukkan bahwa ketika larutan asam pikrat diencerkan oleh molekul HA, yang tidak berwarna harusnya hilang dari larutan, sedangkan anion $\mathrm{A}^{-}$berwarna kuning bertambah. Jika ketebalan lapisan dibuat setengah, cahaya yang melintasi larutan tepat bertemu dengan stengah molekul (atau ion) penyerap cahaya. Efek serupa akan teramati jika konsentrasi larutan setengahnya, dengan asumsi bahwa larutan tersebut mengikuti hukum Lambert-Beer. Namun, ketika larutan asam pikrat kesetimbangannya diganggu oleh konsentrasi anion $\mathrm{A}^{-}$akan berkurang lebih kecil dari setengahnya. Karena itu dapat diasumsikan bahwa keduanya adalah sama, seperti dikerjakan pada metoda penyeimbangan. Hal tersebut juga berlaku ketika keseimbangan antara bentuk warna berbeda dari zat tertentu diganggu oleh perubahan konsentrasi. Sebagai contoh, yaitu pada pembentukan kompleks berwarna (XR) oleh reaksi antara ion yang ditentukan (X) denga reagen $(R)$, dapat diperoleh reaksi penyeimbangan sebagai berikut: 


$$
\begin{aligned}
& \mathrm{X}+\mathrm{R} \leftrightarrow \mathrm{XR} \\
& \frac{[\mathrm{x}][\mathrm{R}]}{[\mathrm{XR}]}=\mathrm{K}_{\text {Inst }}
\end{aligned}
$$

Persamaan ini menunjukkan bahwa kompleks berwarna harus mengurai ketika larutan diencerkan. Akan tetapi, pengurangan intensitas warna ketika larutan diencerkan lebih cepat daripada pengurangan konsentrasi total komples. Terlihat bahwa hukum Lambert-Beer juda tidak dapat diterapkan dalam kasus ini. Namun, jika digunakan kelebihan reagen (R), disosiasi kompleks XR banyak dikurangi sehingga penyimpangan hukum Lambert-Beer dapat diabaikan. Untuk mencapai kondisi ini, maka syaratnya larutan diencerkan tidak dengan air melinkan dengan reagen, sehingga konsentrasi kompleksnya dapat dijaga konstan. Besarnya penyimpangan hukum Lambert-Beerjuga tergantung pada nilai $\mathrm{K}_{\text {Inst }}$ kompleks. Semakin kecil harganya maka penyimpangan dari hukum tersebut akan semakin kecil dan semakin kecil kelebihan reagen yang digunakan unetuk mencegah disosiasi kompleks tersebut.

Hidrolisis zat berwarna akan meningkat dengan pengenceran juga menjadi sebab lain dari penyimpangan hukum Lambert-Beer. Diketahui bahwa hidrolisis dicegah dengan pengaturan $\mathrm{pH}$ larutan. Pengaturan $\mathrm{pH}$ larutan tersebut juga harus diperhitungkan dalam kasus lain. Sebagai contoh warna larutan asam pikrat terbukti sangat dipengaruhi oleh $\mathrm{pH}$ larutan. Hal tersebut terjadi juga pada kompleks yang memiliki yang memiliki ligan $\mathrm{NH}_{3}$, karena $\mathrm{NH}_{3}$ akan bereaksi dengan $\mathrm{H}^{+}$ membentuk $\mathrm{NH}_{4}^{+}$yang stabil. Contohnya pada kompleks $\left[\mathrm{Cu}\left(\mathrm{NH}_{3}\right)_{4}\right]^{2+}$ yang mengurai ketika larutan dibuat asam sehingga reaksi yang terjadi sebagai berikut :

$$
\left[\mathrm{Cu}\left(\mathrm{NH}_{3}\right)_{4}\right]^{2+}+4 \mathrm{H}^{+} \leftrightarrow \mathrm{Cu}^{2+}+4 \mathrm{NH}_{4}^{+}
$$


dan warna biru yang kuat berubah menjadi biru pucat.

b. Pengaruh Ion Lain pada Warna Larutan

Dalam analisis kolorimetri, ion yang akan ditentukan biasanya ada dalam larutan bersama-sama dengan berbagai ion lain yang mungkin juga menginterferensi warna larutan. Hal ini dapat terjadi dsebagai berikut :

$\checkmark$ Ion lain akan membentuk kompleks berwarna dengan reagen yang digunakan, atau bergabung tanpa menghasilkan produk berwarna.

$\checkmark$ Ion lain tersebut memang berwana.

$\checkmark$ Ion lain adalah anion yang telah bergabung dengan kation yang akan ditentukan membentuk senyawa atau kompleks dengan derajat disosiasi rendah.

Dalam penetapan dengan kolorimetri, pengaruh ion lain pada warna larutan harus dihilangkan. Penghilangan tersebut dapat dilakukan dengan metoda fisik atau kimia.

Metoda kimia ini penting dan biasanya digunakan untuk menghilangkan gangguan ion lain adalah masking (penutup). Metoda ini banyak digunakan dalam analisis kuantitatif. Ion lain yang menganggu (M) digabung dalam bentuk kompleks tidak berwarna (MQ) dengan penambahan masking agent (Q). Agar penutupan ini terjadi, kompleks $M Q$ harus lebih stabil daripada kompleks MR yang terbentuk oleh ion penganggu (M) dengan reagen $(R)$.

Sebagai contoh pada penetapan ion $\mathrm{Co}^{2+}$ dalam bentuk kompleks tiosianat $\left[\mathrm{Co}(\mathrm{CNS})_{4}\right]^{-}$; dengan adanya penganggu ion $\mathrm{Fe}^{3+}$ akan dihilangkan dengan penambahan $\mathrm{NaF}$ atau $\mathrm{NH}_{4} \mathrm{~F}$ dalam larutannya, supaya ion ferri membentuk kompleks tidak 
berwarna yang sangat stabil $\left[\mathrm{FeF}_{6}\right]^{3-}$. Pengaruh ion $\mathrm{Fe}^{3+}$ dapat juga dihilangkan dengan asam tartrat atau sitrat, dan pirofosfat.

Ion penganggu juga dapat dihilangkan dengan mengubah valensinya. Sebagai contoh pada pembentukan $\mathrm{F}(\mathrm{CNS})_{3}$ dapat juga dicegah dengan mereduksi $\mathrm{Fe}^{3+}$ menjadi $\mathrm{Fe}^{2+}$, yang tidak membentuk senyawa berwarna dengan $\mathrm{NH}_{4} \mathrm{CNS}$. Kadangkala penggunaan zat pelindung tidak memungkinkan, maka cara yang lain dengan melakukan pemisahan, atau ekstraksi.

\subsection{Metode Pembandingan Warna}

Untuk menetapkan konsentrasi analit dengan perbandingan warna larutan dengan warna standar, maka kedua larutan yang dibandingkan harus pada kondisi yang sama. Prosedur berikut ini digunakan untuk pertimbangan pada metode kolorimetri sebagai berikut :

a. Reagen ditambahkan, dengan urutan dan jumlah yang sama pada kedua larutan standar dan analit.

b. Reaksi reagen dengan kedua larutan berlangsung cepat dan segera diukur (warna larutan sering berubah dengan waktu).

c. Jika analit mengandung ion asing pengganggu, maka pada larutan standar juga harus ditambahkan ion asing tersebut dengan jumlah yang hampir sama.

d. Warna larutan analit dan standar dibandingkan dengan alat yang tepat, yang terbuat dari bahan yang sama, dan penyinarannya harus sama. 
Terdapat 4 (empat) metoda kolorimetri visual, antara lain:

a. Metoda deret standar

Merupakan metoda yang digunakan untuk seri larutan standar analit yang akan ditetapkan dengan konsentrasi berbeda yang berurutan, sehingga akan diperoleh skala kolorimetri.

b. Metoda pengenceran

Merupakan metoda yang hanya digunakan untuk satu larutan standar, dan konsentrasinya dibuat sama dengan analit dan pengenceran. Pengencerannya biasanya dilakukan pada silinder gelas dengan skala milimeter. Pada kedua silinder analit dan standar diletakkan pada rak dan salah satu larutan yang lebih pekat diencerkan sampai warnanya terlihat tepat sama. Volume diukur sebelum dan sesudah pengenceran.

c. Titrasi kolorimetri

Merupakan metoda yang juga hanya digunakan untuk satu larutan standar, akan tetapi pada warnanya disesuaikan agar sama dengan analit dengan penambahan bertetes-tetes dengan buret untuk menentukan unsur larutan standar.

d. Metoda penyeimbangan

Merupakan metoda yang telah dibahas di awal, yaitu yang menerapkan hukum Lambert-Beer. Dengan konsentrasi analit yang dapat ditentukan sebagai berikut :

$$
\mathrm{C}_{\text {Un }}=\mathrm{C}_{\text {St } \mathrm{H}_{\mathrm{un}}} \mathrm{H}_{\mathrm{Ht}}
$$

Instrumen khusus kolorimetri digunakan untuk pembandingan warna dengan variasi kedalaman salah satu larutan. 
Kolorimeter. Merupakan dua silinder berskala masingmasing dengan kran pembuangan. Pertama-tama, larutan analit dan standar dimasukkan ke dalam dua silinder tersebut. Kemudian, kedua silinder tersebut di lihat dari ats dan larutan yang lebih pekat warnanya akan dikeluarkan seacra perlahanlahan ke gelas beaker yang ada di bawahnya. Apabila warna kedua larutan tersebut telah sama, maka dapat dibaca skalanya pada silinder gelas dan dihitung konsentrasi analit dengan rumus di atas.

Fotokolorimetri. Dalam penetapan dengan fotokolorimetri intensitas cahaya yang keluar dari larutan dapat diukur dengan kekuatan arus fotolistrik yang akan dihasilkan oleh penyinaran permukaan sensitif fotosel dan dicatat dengan galvanometer, alatnya disebut fotokolorimetri yang terdiri dari dua jenis berkas tunggal dan berkas ganda. Penetapan konsentrasi analit dapat dilakukan dengan mengalurkan absorbansi (A) terhadap konsentrasi. atau dengan menggunakan rumus sebagai berikut :

$$
\mathrm{C}_{\mathrm{Un}}=\mathrm{C}_{\mathrm{St}} A_{\mathrm{USt}}^{A_{\mathrm{St}}}
$$

\subsection{Rangkuman}

$>$ Analisis kolorimetrik pada banyaknya unsur atau ion yang ada ditentukan dari intensitas warna larutan yang disebabkan oleh adanya senyawa yang berwarna atau telah dibuat menjadi berwarna.

$>$ Metode kolorimetri ini meliputi penyamaan warna analit dengan larutan standar pada kondisi yang sama. 
> Metoda kolorimetri ini sangat sensitif, artinya bahwa metoda ini sangat sesuai untuk penetapan unsur pada konsentrasi sangat rendah, disamping sederhana dan lebih cepat daripada penetapan dengan gravimetri dan volumetri.

$>$ Hukum absorpsi cahaya oleh larutan yaitu apabila cahaya monokromatis dengan intensitas $I_{o}$ yang mengenai lapisan homogen zat, maka sebagian cahaya akan dipantulkan $\left(\mathrm{I}_{\mathrm{r}}\right)$, diserap $\left(\mathrm{I}_{\mathrm{a}}\right)$, dan diteruskan $\left(\mathrm{I}_{\mathrm{t}}\right)$ melewati lapisan tersebut.

\subsection{Latihan Soal}

Kerjakanlah soal di bawah ini sebagai sarana pemahaman anda terhadap materi Analisis

\section{Kolorimetri!}

1. Sebutkan aplikasi dati metode kolorimetri!

2. Jelaskan prinsip metode kolorimetri!

3. Mengapa pada penetapan sampel dengan metode kolorimetri diperlukan larutan standar?

4. Dalam pengukuran kadar besi suatu sampel air diperlukan larutan standar besi dengan konsentrasi 0,1 ; 0,$2 ; 0,5 ; 1,0$; dan 2,5 ppm. Larutan standar besi ini dibuat dari larutan standar 0,0702 g $\mathrm{Fe}\left(\mathrm{NH}_{4}\right)_{2}\left(\mathrm{SO}_{4}\right)_{2} \cdot 6 \mathrm{H}_{2} \mathrm{O}$ dalam 1 liter aquades. Hitunglah cara membuat larutan standar konsentrasi 0,$1 ; 0,2 ; 0,5$; 1,$0 ;$ dan $2,5 \mathrm{ppm}$ ! 


\section{DAFTAR PUSTAKA}

Bassett, J., Denney, R.C., Jeffery, G.H., dan Mendham, J. (1994). Vogel Kimia Analisis Kuantitatif Anorganik. Cetakan pertama. Diterjemahkan oleh Dr. A. Hadyana Pudjaatmaka dan Ir. L. Setiono. Jakarta: EGC.

Chan, C., Lam, H., Lee, Y.C., dan Zhang, X-M. (2004). Analytical Method Validation and Instrument Performance Verification. New Jersey: John Wiley \& Sons.

Day, R.A, dan A.L. Underwood. (1981). Analisis Kimia Kuantitatif. Edisi keempat. Jakarta: Erlangga.

Ham, B.M., Maham, A. (2016). Analytical Chemistry. Canada: John Wiley \& Sons, Inc.

Harris, D.C., Lucy, C.A. (2016). Quantitative Chemical Analysis. New York: Kate Parker Publishing.

Harris, D.C., Laboratory, M. (2011). Solutions manual for Harris' Quantitative Chemical Analysis, Eighth Edition. New York: W.H. Freeman and Company.

Harvey, D. (2000). Modern Analytical Chemistry. Boston: McGrawHill Companies, Inc.

Khopkar, S.M. (1990). Konsep Dasar Kimia Analitik. Jakarta: UI Press. 
Pursitasari, I.D. (2014). Kimia Analitik Dasar dengan Strategi Problem Solving dan Open-Ended Experiment. Cetakan pertama. Bandung: ALFABETA.

Sastrohamidjojo, H. (2005). Kimia Dasar. Edisi kedua. Yogyakarta: UGM Press.

Skoog, D.A. (2004). Fundamentals of Analitical Chemistry Eight Edition. Kanada: Brooks/Cole.

Tim Kimia Analitik. (2000). Dasar-dasar Kimia Analitik. Bandung: Jurdik Kimia UPI.

Widodo, D.S., Hastuti, R., Gunawan. (2009). Analisis Kuantitatif. Semarang: UNDIP Press.

Zaikov, G.E., Haghi, A.K. (2016). Analytical Chemistry from Laboratory to Process Line. Canada: Apple Academic Press. 


\section{BIODATA PENULIS}



Jamilatur Rohmah, S.Si., M.Si. dilahirkan di Sidoarjo, 28 September 1985. Pada tahun 2009, penulis mendapatkan gelar Sarjana Sains dari jurusan Kimia FMIPA Universitas Negeri Surabaya (UNESA). Penulis melanjutkan Magister Kimia dari Institut Teknologi Sepuluh Nopember (ITS) Surabaya. Tahun 2012, penulis secara resmi mendapatkan gelar M.Si. Penulis mengawali karirnya sebagai Dosen di prodi Pendidikan IPA FPIP pada tahun 2014 dan tahun 2015 penulis menjadi Dosen di Prodi Teknologi Laboratorium Medis Muhammdiyah Sidoarjo.

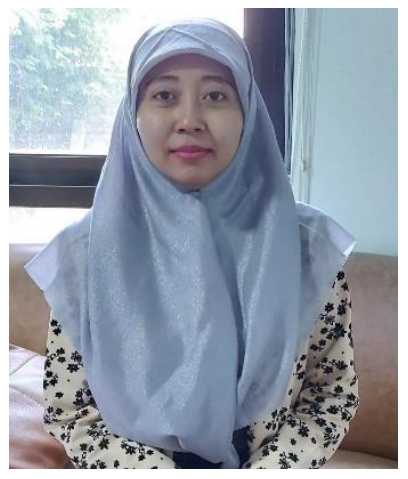

Chylen Setiyo Rini, S.Si., M.Si. lahir di Sidoarjo, 04 April 1985. Lulus sebagai Ahli Mikrobiologi tahun 2013, dan memperoleh gelar Sarjana Sains dari Prodi Biologi MIPA Institut Teknologi Sepuluh Nopember (ITS) Surabaya tahun 2009. Penulis melanjutkan studi S2 di Prodi Biologi Universitas Airlangga (UNAIR) lulus tahun 2013. Karir pendidikan dimulai tahun 2014 di Prodi Teknologi Laboratorium Medis Universitas Muhammadiyah Sidoarjo. 
